\title{
A Theory of Establishment Clause Adjudication: Individualism, Social Contract, and the Significance of Coercion in Identifying Threats to Religious Liberty
}

\author{
Robert A. Holland
}

TABLE OF CONTENTS

I. Introduction...................................... 1599

II. The Supreme Court's Establishment Clause Decisions ...... 1602

A. Economic Assistance to Religion ................. 1603

1. Educational Setting: Aid to Parochial Schools ...... 1603

2. Noneducational Setting ...................... 1613

a. Official Acknowledgment of Religion: State-

Sponsored Christmas Displays............... 1613

b. Granting Unemployment Benefits to Accommodate Religious Beliefs ............. 1616

c. Tax Exemptions for Various Religious Institutions and Activities ................. 1617

B. Noneconomic Assistance to Religion................ 1618

1. Educational Setting: Religion in the Public

Schools ................................. 1618

a. Released Time Programs .................. 1618

b. Rehigious Activities Led by Public School

Teachers .............................. 1619

c. Rehigious Objects in the Classroom ........... 1621

d. Rehigious vs. Secular Content of the Public

School Curriculuin........................ 1622

e. Equal Access for Religious Organizations to

Public School Facilities .................... 1623

2. Noneducational Setting .................... 1624

a. Official Acknowledgment of Religion .......... 1624

b. Regulatory Laws or Exemptions Favoring

Religion ............................ 1628

C. Conclusion: The Need for Umifying Principles ....... 1630 
III. Theoretical Underpinnings of the Religion Clauses: Individualism, Social Contract, and the Primacy of Rehigious Liberty

A. The Dimensions of Liberal Individualism ........... 1631

B. Individuahsm im the Social Context: Social Contract Theory ................................... 1634

C. Freedom of Conscience as a Fundamental Individual Liberty Under Contractarian Theory ............... 1637

D. First Amendment Protection of Freedom of Conscience: Religious Liberty as the Core Value Underlying the Establishment Clause and the Primary Guide to Estabhishment Clause Interpretation......... 1638

1. Consistent Concern for Individual Religious Liberty in the Drafting of the First Amendment and in the Supreme Court's Establishment Clause Jurisprndence ............................. 1638

2. Primacy of Rehigious Liberty over Other Possible Values Underlying the Establishment Clause ...... 1641

3. The Principle of Religious Liberty as the Sole Guide to Constitutional Interpretation: The Inadequacy of Original Intent .......................... 1650

IV. Disjuncture Between Theory and Law: Inability of Existing Establishment Clause Tests to Ensure Rehigious Liberty .... 1653

A. The Lemon Test: The Impossibility of Strict

Neutrality ............................... 1653

1. The Effect Prong of the Lemon Test ............. 1653

2. The Lemon Test as a Threat to Rehigious Liberty .. 1655

B. The Endorsement Test: The Unfulfilled Promise of Symbohic Neutrahty ............................. 1658

1. Dimensions of the Endorsement Test: Lynch v. Donnelly................................. 1659

2. Deficiencies in the Endorsement Test ........... 1660

a. Terminology Without Content: The Insurmountable Barrier to Implementation...... 1660

b. Irrelevance and Incompatibility: The Failure of the Endorsement Test to Guard Individual Religious Liberty ...................... 1663

V. Protecting Individual Religious Liberty: A Coercion-Based Test ....................................... 1666

A. The Significance of Coercion to the Drafters of the First Amendment and to Supreme Court Justices ..... 1666

B. Previous Attempts to Formulate a Coercion Test...... 1670

C. The Proposed Test.............................. 1672

1. Defining Coercive Effect................... 1673 
2. Determining when the Coercive Effect Is

Impermissible ............................... 1676

VI. Applications of the Coercion Test .................. 1681

A. Economic Aid to Rehigion ................... 1682

1. Educational Setting: Aid to Parochial Sclrools ..... 1682

2. Noneducational Setting ..................... 1684

B. Noneconomic Aid to Religion .................. 1687

1. Educational Setting: Religion in the Public

Schools ................................... 1687

2. Noneducational Setting .................... 1691

VII. Conclusion ................................... 1694 



\title{
A Theory of Establishment Clause Adjudication: Individualism, Social Contract, and the Significance of Coercion in Identifying Threats to Religious Liberty
}

\author{
Robert A. Holland $\dagger$
}

The Supreme Court has struggled to produce a coherent and consistent Establishment Clause jurisprudence to regulate the interaction between religion and government. This Comment suggests that a specific value_religious liberty-should animate the Court's decisions in the area. The Comment begins by highlighting the analytic shortcomings and logical inconsistencies in the major Establishment Clause cases. It then argues that while contractarian political philosophy and an overriding concern with freedom of conscience lie at the root of the Establishment Clause, existing judicial tests do not adequately protect the corresponding core value of religious liberty. The Comment suggests that an alternative test, one based on the presence of coercion, better promotes religious liberty. The Comment explores the difficulties with previous formulations of a coercion-based test and suggests how a superior test might be drafted. It then articulates a new standard under which government actions are deemed to establish religion if they impermissibly coerce individuals' religious beliefs or activities. Finally, the Comment demonstrates the proposed test's usefulness by applying it to specific fact patterns.

INTRODUCTION

In 1971, the Supreme Court held in Lemon v. Kurtzman ${ }^{1}$ that action by the federal government or by a state government that confers a benefit on any rehigious group violates the Establishinent Clause of the

$\dagger$ B.A. 1990, University of California, Irvine; J.D. candidate 1993, Boalt Hall School of Law, University of California, Berkeley. I am indebted to Professor Jesse H. Choper for his substantive guidance and to Danny Cloherty and Ben Douglas for their excellent editorial assistance. This Comment is dedicated to Robert E. Holland (1911-1992), my grandfather, who exemplified the ideal balance between religious faith and rehigious toleration, and without whon neither my law school experience nor this Comment would have been possible.

1. 403 U.S. 602 (1971). 
First Amendment to the Umited States Constitution" unless it has a "secular legislative purpose[,] . . . its principal or primary effect . . . neither advances nor inhibits religion," and it does "not foster "an excessive gov. ernment entanglement witl rehgion." "3 The Court reasoned that although action that fails to meet these three requirements may not "establish a state religion," it still violates the First Amendment because it is a "step that could lead to such establishment." In announcing this three-part test, the Court looped to prevent what it perceived to be the "three main evils against which the Estabhishment Clause was intended to afford protection: 'sponsorship, financial support, and active involvement of the sovereign in religious activity." "6

Since that time, the Court lias struggled to articulate the range of government actions that are invalid under the Lemon test by trying to give content to essential words like "purpose," "effect," "advance," and "inhibit"7 and seeking to reconcile its more recent looldings with those prior to Lemon. Its latest step in this articulation process is Lee $v$. Weisman, ${ }^{8}$ in which the Court considered the validity of an invocation and benediction at a public high school commencement ceremony. ${ }^{9}$ In urging the Court to allow the practice, the school board argued that the Court should focus only on the effect of the government's action by "ask[ing] whether the exposure to the government's rehigious expression is voluntary, and whether the governmental practice coerces rehgious behief." 10 Notwithstanding this argument, however, the Court struck down the practice. ${ }^{11}$ The Court rested its conclusion primarily on its perception that the students at the graduation were indirectly coerced into participating in a rehigious activity. ${ }^{12}$

Although the school board's proposal made a definition of "purpose" unnecessary and purported to give content to the word "advance," its fornulation was too vagne to assist the Court in its articulation process. Specifically, the board's proposal failed to define adequately what

2. "Congress shall make no law respecting an establishment of religion ...." U.S. CoNST. amend. I.

3. Lemon, 403 U.S. at $612-13$ (quoting Walz v. Tax Comin'n, 397 U.S. 664, 674 (1970)).

4. Id. at 612 .

5. Id.

6. Id. (quoting Walz v. Tax Coinm'n, 397 U.S. 664,668 (1970)).

7. For the most noteworthy attempt, sec Wallace v. Jaffree, 472 U.S. 38, 69 (1985) (O'Connor, J., concurring) ("The endorsement test is useful because of the analytic content it gives to the Lemon-mandated inquiry into legislative purpose and effect."). The concept of endorsement was designed primarily to define the term "advance." Once this term is defined, it becomes easier to identify impermissible purpose and effect.

8. 112 S. Ct. 2649 (1992).

9. Id. at 2655 .

10. Arguments Before the Court-Schools and Colleges-Benediction at Graduation Ceremony-Establishment Clause, 60 U.S.L.W. 3351, 3351 (1991).

11. Lee, 112 S. Ct. at 2661.

12. Id. at 2658. 
constitutes voluntary exposure and what constitutes coercion. Because the Court seened to feel intuitively that the students were coerced in this instance, it felt no need to articulate a specific definition of coercion to guide future inquiries. ${ }^{13}$ Instead, the Court appeared to treat the perceived coercive pressure as just another form of the "advancement" of religion forbidden by Lemon. This approach relieved the Court of the burden of defining either "advancement" or "coercion."14

This Comment argues that the school board's proposal and the Court's reasoning, though far from adequate, employ the construct best suited to resolving Establishment Clause cases: coercion. This argument rests on several foundational propositions. First, hiberal individualism is the fundamental theoretical tradition that animates constitutional protections and therefore should guide constitutional interpretation. Second, out of this individualist tradition has emerged a Lockean social contract model which further guides constitutional interpretation by identifying and justifying some limits on individual liberties in civil society. Third, since individual freedom of conscience is necessarily fundamental under the social contract inodel, that right should receive special protection; the First Amendment embodies this special concern for freedom of conscience. Fourth, because freedom of conscience is so fundamental, individual rehigious hiberty in particular must be the core value animating the Establishment Clause and should, accordingly, direct courts' interpretation of the Clause; further, all other proposed values underlying the Estabhishment Clause are, at most, secondary to individual religious biberty.

Given these propositions, the two most prominent Establishment Clause tests-the Lemon test and Justice O'Connor's endorsement test ${ }^{15}$-are deficient because they fail to protect adequately individual religious liberty. Indeed, in some cases, these tests even threaten that liberty. Only a coercion-based standard for adjudicating Establishment Clause violations appears to guard adequately individual freedom of religion. Accordingly, the goal of this Comment is to articulate such a standard to guide the courts in identifying government action that violates the Establishment Clause.

To establish these foundational propositions and accomplish its

13. Id.

14. The Lee Court noted that the district court had held that the practice violated the effect prong of the Lemon test, so the district court did not reach Lemon's other prongs. Id. at 2654. Therefore, the Suprene Court's inquiry necessarily focused only on the validity of the district court's assessment of religious effect.

15. See Lynch v. Donnelly, 465 U.S. 668, 690 (1984) (O'Connor, J., concurring) ("The purpose prong of the Lemon test asks whether government's actual purpose is to endorse or disapprove of religion. The effect prong asks whether ... the practice under review in fact conveys a inessage of endorseinent or disapproval."). For a more comprehensive discussion of the endorsement test, see infra text accompanying notes 110-18, 403-38. 
goal, this Comment proceeds in six Parts. Part II discusses the Court's major Establishment Clause decisions to highlight the logical inconsistencies among results reached and among rationales used. This discussion should make clear the need for a coherent theory of Establishment Clause adjudication. Part III articulates the individualist and contractarian underpinnings of the First Amendment. It deinonstrates that individual rehigious hiberty is the primary value that the framers and the courts have sought to protect and should therefore inform the courts' selection of a legal standard. Part IV shows that neither the Lemon test nor the endorseinent test sufficiently protects the individual rehgious liberty contenplated by the Rehigion Clauses. Part V articulates a standard that makes Establishment Clause violations contingent on a showing of coercion. It defines coercion and shows how the definition is apphed. Part VI apphies the proposed test to a variety of situations the Court has considered over the past fifty years. Part VII concludes that a coercionbased test best protects rehgious liberty.

\section{II}

\section{The Supreme Court's Establishment Clause DECISIONS}

This Part divides the Supreme Court's Estabhishment Clause decisions into those imvolving economic assistance to religion and those involving noneconomic assistance. Both of these mam subdivisions are further divided according to whether the cases arise in an educational or a noneducational setting. The use of these categories has two advantages. First, it creates a clear framework for the applications of this Comment's proposed coercion test because each category raises a particular combination of issues that the coercion test views as somewhat distinctive. ${ }^{16}$ Second, this breakdown best fulfills the purpose of Part II-to demonstrate the depth of inconsistency in the Supreme Court's Establishment Clause jurisprudence.

Various analytic flaws do recur in the Supreme Court's Establishment Clause decisions over the last fifty years. Although it might make sense to organize this discussion according to those flaws,

16. For example, in cases where the government provides economic assistance for religious activities, the only question is whether taxpayers are impermissibly forced to aid religion. In contrast, where the government provides noneconomic assistance to religion, such as allowing religious activities in public school classrooms, making public land available for religious displays or activities, or exempting religious groups from certain kinds of regulations, the issue is whether this treatment of religious groups impermissibly penalizes those who are not members of those groups by placing psychological pressures or social stigma on them. The educational setting raises unique psychological issues because children are presumably less able to withstand this kind of pressure, and might therefore adopt religious practices or beliefs just to avoid what they perceive to be punishments. The uniqueness of these issues and, therefore, the reason for this organization should become much clearer when the Comment's proposed coercion test is set out and applied to these same fact situations. 
such an organization would group together cases with vastly different fact patterns, because the analytic shortcomings are not restricted to any one category of Establishment Clause cases. Instead, this discussion will group togetlier cases wliose facts are intuitively similar in order to higl1light the different results reaclied in sucl similar cases and to denonstrate the extent to which the Court's analytic flaws lead to unpredictable and inconsistent results.

\section{A. Economic Assistance to Religion}

\section{Educational Setting: Aid to Parochial Schools}

The inconsistencies in the Court's approacl to the Establishment Clause began to appear as early as its first inajor contemporary Establishment Clause case, Everson v. Board of Education. ${ }^{17}$ The Everson opinion provides one of the most famous and sweeping statements on tlie extent to whicl church and state inust be kept separate:

The "establishment of religion" clause of the First Amendment means at least this: Neither a state nor the Federal Government can set up a churcli. Neither can pass laws which aid one religion, aid all religions, or prefer one religion over anotlier. Neither can force nor influence a person to go to or to remain away from cliurcli against his will or force him to profess a belief or disbehief in any rehigion. No person can be pumshed for entertaining or professing religious beliefs or disbeliefs for churcl1 attendance or nonattendance. No tax in any amount, large or small, can be levied to support any religious activities or institutions, whatever they inay be called, or whatever form they inay adopt to teach or practice religion. Neitlier a state nor the Federal Government can, openly or secretly, participate in the affairs of any rehigious organizations or groups and vice versa. In the words of Jefferson, the clause against establishment of religion by law was intended to erect a "wall of separation between church and State."18

Despite this sweeping language, the Everson Court upheld a New Jersey statute authorizing the use of tax dollars to reimburse parents for the costs of transporting their children to parochial schools on public transit buses.

The Court attempted to reconcile the logical inconsistency between the language and tlie holding in two ways. First, it analogized the rein1bursement of bus fares to tlie provision of ordinary fire protection, potice

17. 330 U.S. 1 (1947).

18. Id. at 15-16 (quoting Reynolds v. United States, 98 U.S. 145, 164 (1878) (referring to a statement by Thomas Jefferson in support of the Establishment Clause)). 
assistance, and sewage disposal, ${ }^{19}$ all of which aid religious activities and institutions. However, the Court did not attempt to reconcile the provision of these ordinary services with its sweeping language prohibiting the use of any tax dollars to aid religious institutions.

Second, the Court simply declared that the reimbursement did not amount to "support" for parochial scliools because the reimbursement was available to parents of all children, regardless of their religion. ${ }^{20}$ The Court conceded that the reimbursements may have enabled some children to attend parochial schools when they might otherwise liave been forced to attend public schools. ${ }^{21}$ It failed to explain, however, why this benefit to religious institutions should not fall under its sweeping prohibition.

The Court inay have meant that the remiburseinent was valid because the state did not intend specifically to aid religion. However, the Court did not express this meaning. Nor did it reconcile its holding with its prohibition against the use of tax dollars to benefit religious institutions, which made no mention of purpose or intent. As Justice Jackson noted in his dissent, "undertones of the opinion advocating complete and uncompromising separation of Church from State seem utterly discordant with its conclusion yielding support to their commingling in educational matters."22

These inconsistencies resurfaced and multiphed in Board of Education v. Allen, ${ }^{23}$ which upheld a New York statute authorizing public school boards to lend secular textbooks purchased with public funds to students attending public or private (including parochial) schools. ${ }^{24}$ Allen incorporated Everson's mconsistency between rationale and holding by adopting both Everson's broad prohibition against the use of tax money to support rehgious institutions and Everson's inadequate reconciliation of that language with the holding that the challenged subsidies were permissible. ${ }^{25}$ This imcorporation allowed the Allen Court to uphold the New York statute sinuply by analogizing it to the one uplield in Everson. ${ }^{26}$

19. Id. at $17-18$.

20. Id. at 18 ("The State contributes no money to the schools. It does not support them. Its legislation, as applied, does no more than provide a general program to help parents get their children, regardless of their religion, safely and expeditiously to and from accredited schools.").

21. Id. at 17.

22. Id. at 19 (Jackson, J., dissenting).

23. 392 U.S. 236 (1968).

24. Id. at 238 .

25. See id. at 241-42.

26. In reviewing the Everson decision, the Allen Court declared, "Nevertheless, said the Court [in Everson], the Establishment Clause does not prevent a State from extending the benefits of state laws to all citizens without regard for their rehious affiliation." Id. at 242. In upholding the challenged statute, the Allen Court stated that "[t]he law merely makes available to all children the benefits of a general program to lend school books free of charge." Id. at 243. 
In addition, Allen adopted a separate legal test that was inconsistent with Everson's sweeping prohibitions. According to the Allen Court:

"The test may be stated as follows: what are the purpose and the primary effect of the enactment? If either is the advancement or imhibition of rehion then the enactment exceeds the scope of legislative power as circumscribed by the Constitution. That is to say that to withstand the strictures of the Establishment Clause there must be a secular legislative purpose and a primary effect tliat neither advances nor inhibits religion."27

Although the "purpose" component of this test readily explains tlie holdings in both Everson and Allen, and althougli the Everson Court may have liad some notion of purpose in mind when it uplield tlie reimbursement statute, Everson's actual language makes no mention of purpose.

The Allen Court plausibly reconciled its own holding with the new legal standard. ${ }^{28}$ It noted that the purpose of the challenged statute was secular. ${ }^{29}$ It also determined that the statute's primary effect was not to advance or inhibit rehigion. ${ }^{30}$ Although the Allen Court did not define "primary," it apparently meant that if the government did not make aid

27. Id. (quoting School Dist. v. Schempp, 374 U.S. 203, 222 (1963)). The test quoted here originated in Schempp. For a discussion of the specific facts of Schempp that gave rise to the Court's articulation of the test in that case, see infra text accompanying notes 149-56.

28. Justice Black, who dissented in Allen, attempted to distinguish the facts of Everson froin those of Allen by asserting that, unlike bus rides, books "will in some way inevitably tend to propagate the religious views of the favored sect." Allen, 392 U.S. at 252 (Black, J., dissenting). However, the law authorized only "secular" books to be loaned to private schools; it is difficult to see how a secular book can facilitate the incnlcation of religious ideas. If Black meant that parochial schools will exercise their discretion to choose books by borrowing books that are biased iu favor of religious ideas, see id. at 256 (Douglas, J., dissenting), this objection seeıns unfounded because any book that is authorized to be loaned under the New York law must be sufficieutly "secular" to pass constitutional scrutiny. See 392 U.S. at 245 . If Black meant that a book merely facilitates the teaching of a class in general and that once religious teachers begin teaching a class they are in a position to inculcate religious ideas, then lending textbooks is no different from reimbursing bus fares, because the bus ride places a child into a classroom environment and in front of a teacher who can then inculcate religious ideas.

Even if Justice Black's objections were valid, he did not make it clear whether they were meant to show that the law at issue violated Everson's sweeping prohibition or the new legal standard employed in Allen. It is clear that the law violated Everson's rule. However, Black did not seen to object to the textbook law on the basis of Everson. Rather, he merely declared that the law would facilitate "propagation" of religious beliefs. The Allen Court did not deny this causal relationship; rather, it held that the propagation is permissible as long as the government program actually serves an independent secular purpose. Id. If Black was arguing that the Allen holding is inconsistent with the Allen standard, he was unconviucing.

29. The Court noted that "[t]he express purpose of [the statute] was stated by the New York Legislature to be furtherance of the educational opportunities available to the young." Id. Although the Court appeared to accept this statement without investigation into its sincerity, it did at least focus on the expressed motivations of the legislators and not on the mere possibility that a judge could devise a plausible "secular" rationale for the law.

30. The Court stated that the appellants liad shown "nothing" in the effect of the statute that was "contrary to its stated purpose." Id. 
to religious institutions a necessary precondition to fulfillment of the statutory purpose, but ratlier inade the aid derivative of the effect of fulfilling the stated statutory purpose, then the statute would be constitutional. ${ }^{31}$

However, the Allen Court may not have defined "primary" this way. The Court noted that the "degree of support" that the book program created "for a religious institution" did not amount to a constitutional violation..$^{32}$ A quantitative evaluation of effect would be inconsistent witl the primary/derivative effect approach because it would focus simply on whether a law provided more aid to religion than the Court was willing to accept rather than on whetlier the aid to religion was absolutely necessary to achieve the desired secular effect. However the Court defined "primary," the holding is arguably consistent witl the test that it announced.

The Court's approach became even less consistent in Lemon $v$. Kurtzman, ${ }^{33}$ a decision that aimed to resolve previous inconsistencies among results and rationales. In Lemon, the Court struck down two state statutes that provided reimbursement to private (including parochial) schools for teachers' salaries, textbooks, and educational inaterials in designated secular subjects. ${ }^{34}$ The Court stated that government action benefitting religion must ineet the "purpose" and "primary effect" requirenents discussed in Allen. ${ }^{35}$ Lemon also added a new requireinent that sucli action inust "not foster 'an excessive government entanglement witl religion." "36

The Lemon Court reasoned that to ensure the validity of the statutory scheme, the State would liave to ensure that no materials were used in the schools for religious purposes and that no teachers wliose salaries were subsidized taught religion. ${ }^{37}$ This inonitoring process, the Court believed, would create an impermissible entangleinent of the government in the affairs of religious sects. ${ }^{38}$ The statute was therefore held unconstitutional.

Although Lemon's holding was consistent with its new three-prong test, the new standard deviated from those einployed in prior cases involving affirmative state aid to parochial schools. More significantly, Lemon's holding is arguably inconsistent with Allen's. In Allen, the

31. See id. The Court noted that the "law merely makes available to all children the benefits of a general program to lend school books free of charge." Id. (emphasis added). If the program's objective was to provide educational supplies to all children, then the program's aid to religious schools was not made necessary to the fulfillment of the statutory purpose; it was logically necessary to fulfill that purpose.

32. Id. at 244 .

33. 403 U.S. 602 (1971).

34. Id. at 606-07.

35. Id. at 612 .

36. Id. at 613 (quoting Walz v. Tax Comm'n, 397 U.S. 664, 674 (1970)).

37. Id. at 619 .

38. Id. at $619-20$. 
Court was not disturbed by the possibility that parochial school teachers would use secular textbooks to facilitate rehgious instruction. ${ }^{39}$ Nevertheless, the Lemon Court did not overrule or express an opinion about the viability of the Allen holding, even though the same concerns about inonitoring the conduct of teachers who receive state-funded resources were present in both cases.

In Committee for Public Education \& Religious Liberty v. Nyquist, ${ }^{40}$ the Court purported to follow precedent by applying the Lemon test. ${ }^{41}$ Nyquist involved New York legislation granting state funds for " "inaintenance and repair of ... [non-public] school facilities and equipnent to ensure the health, welfare and safety of enrolled pupils," "42 reinibursement of non-public school tuition, and tax relief for parents who failed to qualify for the reinibursement. ${ }^{43}$ Although the Court conceded that the legislation was motivated by a legitiniate secular purpose, 44 it concluded that it failed the "effects" test by inipermissibly advancing religion. ${ }^{45}$ The Court reasoned that the maintenance and tuition grant provisions were mvalid because they did not ensure that the money would not be used to finance religious education. ${ }^{46}$ The Court cited the sweeping language of Everson to support this conclusion, ${ }^{47}$ but failed to reconcile its use of the effects test with Everson's outright ban on the use of any tax money to help religious imstitutions.

In its discussion, the Court noted specifically that the disbursement of the money to parents of parochial school students rather than directly to the schools did not necessarily validate the resulting benefit to religious educational institutions. ${ }^{48}$ Nevertheless, it indicated that this distriction was "one among many factors to be considered." 49 The Court did not explain, however, why direct subsidies to institutions are, for constitutional purposes, functionally different than indirect subsidies to parents.

Ultimately, the Court's attempts to apply consistently the new Lemon test have failed. In Wolman v. Walter, ${ }^{50}$ the Court considered whether various forns of state aid to non-public schools were permissi-

39. Board of Educ. v. Allen, 392 U.S. 236, 245 (1968) ("[W]e cannot assume that school authorities . . . are unable to distinguish between secular and religious books . . ..").

40. 413 U.S. 756 (1973).

41. Id. at 773-74.

42. Id. at 762 (quoting N.Y. Educ. LAw $\S 550(5)$ (McKinney 1972)).

43. Id. at $764-65$.

44. Id. at 773 .

45. Id. at $779-80$.

46. Id. at 780 .

47. Id. (quoting Everson y. Board of Educ., 330 U.S. 1, 16 (1947)); see supra text accompanying note 18 .

48. Nyquist, 413 U.S. at 785-86.

49. Id. at 781 .

50. 433 U.S. 229 (1977). 
ble. First, it held that a statute allowing public school boards to loan secular textbooks to parochial schools was valid. ${ }^{51}$ Although this holding is consistent with the holding in Allen, it appears to raise the same entanglement concerns that invalidated the statute in Lemon. ${ }^{52}$

Second, the Wolman Court held that state-subsidized standardized testing of non-public school students was constitutional. ${ }^{53}$ Although this holding is clearly at odds with the Everson prohibition, it is arguably consistent with Lemon. Since only public einployees were involved in the drafting and scoring of the tests, ${ }^{54}$ the danger of entangleinent was lower than it was in Lemon. On the other hand, the Court seeined unconcerned about the possibility that those administering the test inight use it to facilitate some type of rehigious instruction.

Third, the Wolman Court upheld the provision of speech and hearing diagnostic services by public einployees on non-public school grounds. $^{55}$ The Court found that there was hittle risk of pressure being exerted by sectarian school officials on diagnostic personnel, and therefore there was hittle danger that sectarian values would be transinitted to the children. ${ }^{56}$ However, while secular textbooks have no "religious" content, they might be used to inculcate rehigious ideas. ${ }^{57}$ Thus, any distinction between secular textbooks and diagnostic tests inust be quantitative rather than qualitative. Accordingly, the Court noted that the amount of contact between the educational enployee and the child is much less in the diagnostic context than it is in the regular educational context. ${ }^{58}$ However, basing inquiries inerely on the risk of harm without specifying the acceptable risk levels in advance gives a great deal of discretion to judges and thus risks a coinplete lack of umfornity in Establishment Clause jurisprudence.

Fourth, the Wolman Court upheld the provision of "therapeutic" services by public einployees to non-public school students. ${ }^{59}$ Although the services were to be offered at public locations or in inobile units off non-public school properties, ${ }^{60}$ the Court observed that where the therapeutic facilities served only non-public students, "a therapist nnay estabhish a relationship with the pupil in which there inight be opportunities to transmit ideological views." ${ }^{21}$ Nevertheless, the Court concluded that

51. Id. at 238.

52. See supra text accompanying note 39 .

53. Wolman, 433 U.S. at 241.

54. Id. at 239.

55. Id. at 244.

56. Id.

57. See Board of Educ. v. Allen, 392 U.S. 236, 252 (1968) (Black, J., dissenting); see also supra note 28.

58. Wolman, 433 U.S. at 244.

59. Id. at 248 .

60. Id. at 245 .

61. Id. at 247 . 
the dangers of indoctrination were minimized because the challenged services were offered at "religiously neutral locations." 62 In reaching this conclusion, however, the Court provided no basis for its assumption that the "pressures of the environment" might cause a public employee to "alter his behavior from its nornal course."63 It also failed to explain how the precise location of the facility has any bearing on the existence of those "pressures" or how the threat of transmitting ideological views through therapy at a neutral site offends the Constitution any less than it would on non-public school grounds. ${ }^{64}$

The Wolman Court did hold that the state's provision of instructional materials to non-public schools was unconstitutional. ${ }^{65}$ Those materials included projectors, tape recorders, record players, maps and globes, science kits, and weather forecasting charts. ${ }^{66}$ The Court reasoned that these items could be used for both religious and secular purposes and that no attempt was made to separate the uses. ${ }^{67}$ The Court did not explain, though, why a map or globe could be used more easily than a geography textbook to indoctrinate children.

Finally, the Wolman Court invalidated the provision of state funds for non-public scliools' field trip transportation. ${ }^{68}$ The Court noted in particular that the recipient schools exercised broad discretion about the "timing of the trips and, within a certain range, their frequency and destinations." 69 For this reason, the Court deemed the "schools, rather than the children," to be the true recipients of the funds. ${ }^{70}$ The Court did not explain why the benefit to the schools in Wolman was any greater than it was in Everson. Indeed, a strong argument could be made that because subsidizing the transportation of so many children to parochial school every day ensured their presence in rehigious classes, the expenditures im Everson advanced religion much more than subsidies for rehigious schools' field trip transportation.

In Aguilar v. Felton ${ }^{71}$ and School District v. Ball, ${ }^{72}$ the Court continued to reveal an Establishinent Clause jurisprudence that rests on ad hoc judgments about the risk of indoctrination. In Aguilar, the Court struck down a provision that authorized the state to fund programs at public

62. Id.

63. Id.

64. Admittedly, it could be argued that because the services are provided to the studeuts offcampus, any risk of harm could be deemed de minimis. However, the Court in Wolman did not construct this kind of argumeut.

65. 433 U.S. at 251 .

66. Id. at 249.

67. Id. at 251 .

68. Id. at 255 .

69. Id. at 253 .

70. Id.

71. 473 U.S. 402 (1985).

72. 473 U.S. 373 (1985), overruled by Bowen v. Kendrick, 487 U.S. 589 (1988). 
and private schools in order to "ineet the needs of educationally deprived children from low-incoune families."73 The Court declared that the monitoring required to ensure that the funds were used for secular purposes would result in too inuch entanglement between the state and religion. ${ }^{74}$

In reaching this conclusion, the Court did not explain why the level of entangleinent here was too great while the level of entangleinent required to momitor therapeutic and diagnostic activities in Wolman was acceptable. The only possible distinction is that the Court assuned in Wolman, but not in Aguilar, that indoctrination would not occur, that monitoring was not needed, and therefore that entanglement was not an issue. But this is precisely the kind of assuinption that the Nyquist Court prohibited. $^{75}$

Similarly, in Ball, the Court struck down two prograins that "provide[d] classes to non-pubhic school students at public expense in classrooms located in and leased froin the local non-public schools."76 The Court reasoned that the danger of indoctrination of the non-public school students by the teachers was impermissibly great. ${ }^{77}$ The Court did not reach the entanglement issue because no attempt had been made in either prograin to inomitor the ainount of contact between religiousschool officials and the state-funded teachers. ${ }^{78}$

The Court changed its approach when it was confronted in Witters

73. 473 U.S. at 404,408 .

74. Id. at 409-14.

75. Committee for Pub. Educ. \& Religious Liberty v. Nyquist, 413 U.S. 756, 778-79 (1973). The Nyquist Court cited Lemon v. Kurtzman, 403 U.S. 602 (1971), in which the Court held that a Rhode Island statute subsidizing the salaries of parochial school teachers could not escape Establishment Clause scrutiny on a mere assumption that the teachers could divorce their religious convictions from their secular duties. Id. at 619. Instead, the Lemon Court required some attempt to monitor teachers' activity in order to satisfy the effects prong of its new test. Id. at 615-22. The Nyquist Court relied on this holding im Lemon to invalidate a statute that gave parochial schools up to $50 \%$ of the amount expended for maintenance and repair in comparable public schools. Nyquist, 413 U.S. at 779-80. The Nyquist Court reached this conclusion even though there was, statistically, a low probability that the parochial schools would have enough of the state funds left over after maintenance and repairs to spend any on rehigious activities or instruction. By ruling as it did, the Nyquist Court declared, at a ininimuin, that a mere assumption that parochial school administrators or teachers can separate their rehigious beliefs from their seeular responsibilities cannot validate state aid under the Establishment Clause. If this general declaration is obeyed, it follows that a statute like the one in Wolman cannot be valid based on a mere assumption that state money is not used by the therapists and diagnosticians to indoctrinate students.

76. 473 U.S. at $375,380-81$. The two programs invalidated by the Court were called the "Shared Time Program" and the "Community Education Program." Under the Shared Time Program, public school teachers provided instruction to non-public students. This instruction was not part of the core curriculum that the state required in all schools; rather, it was supplententary instruction in remedial and "enrichment" mathematics, reading, art, music, and physical education. Under the Community Education Program, the state provided funds for non-public schools to hold classes in arts and crafts, home economics, foreign languages, athletics, drama, and journalism. The classes were taught by non-public school teachers on non-public school grounds. In many cases, these classes were not available through the public school system. Id. at 375-77.

77. Id. at $386-88$.

78. Id. at 387. 
v. Washington Department of Services for the Blind ${ }^{79}$ with a vocational assistance program that provided funds to a blind person studying at a Christian school to become a minister. The.Witters Court noted that the purpose of the state's vocational assistance program was legitimately secular. ${ }^{80}$ It then concluded that the effect of the program was constitutionally permissible. ${ }^{81}$

The logic by which the Court arrived at this conclusion is particularly questionable. The Witters Court offered four observations to support its finding of permissible effect. First, it noted that the program was less problematic than those considered in Ball because the assistance was not given directly to the school. ${ }^{82}$ Indeed, the Court made the remarkable claim that the program did not amount to state action subsidizing religion at all. ${ }^{83}$ It did not explain, however, why this distinction did not save the tuition grants in Nyquist. Second, it noted that the benefits were made available regardless of whether the recipient attended a public or private institution. ${ }^{84}$ But the Court failed to explain why the availability of funds to both public and private institutions did not vahidate the program in Aguilar. Third, the Court noted that "nothing in the record indicates that, if petitioner succeeds, any significant portion of the aid expended ... will end up flowing to rehigious education." 85 However, the Court failed to explam why the amount of aid flowing to religion matters or exactly how much aid is constitutionally impermissible. Fourth, the Court noted that the program did "not seem well suited to serve as the vehicle for ... a subsidy [to religious institutions]"86 and, therefore the "function of the ... program is hardly 'to provide desired financial support for non-public, sectarian institutions." "87 However, this assessment merely highliglited what the Court liad previously established-tliat the purpose of the program was secular.

Finally, in Mueller v. Allen, ${ }^{88}$ the Court upheld a Minnesota statute that allowed tax deductions for educational expenses such as tuition, textbooks, and transportation. ${ }^{89}$ Mueller's reasoning is inconsistent with the rationales and results of prior cases.

The Mueller Court noted that the challenged prograin was available

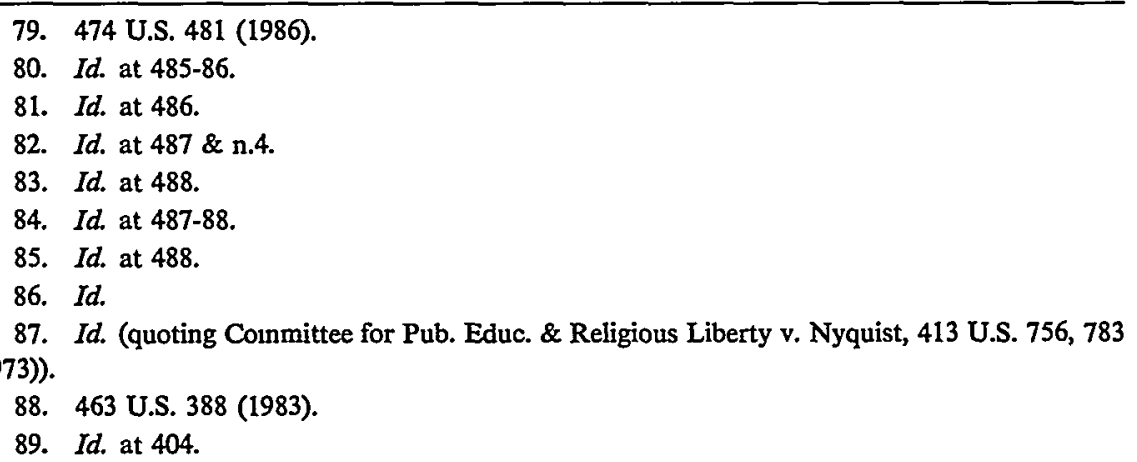


to parents of children attending public as well as private schools. ${ }^{90}$ However, it neither explained why the same feature did not save the program in Aguilar nor explicitly overruled Aguilar. Further, the Court did not explain why this feature should have any bearing at all on its decision. Presumably, a legitimate secular motive could cause a legislature to give benefits only to private schools. It is hard to see how the existence of an impermissible advancement of religion necessarily depends on whether public schools receive the same benefits that private schools receive. ${ }^{91}$

The Mueller Court admitted that it struck down the state assistance in Nyquist even though the funds went directly to parents. ${ }^{92}$ The Court attempted to distinguish Mueller from Nyquist by arguing that the Nyquist program was unconstitutional because it applied only to nonpublic schools. ${ }^{93}$ It is unclear, though, why providing the exemption to parents rather than to schools should change the result. Indeed, the Court admitted that the "economic effect [is] comparable to that of aid given directly to the schools." 94

The Mueller majority also failed to justify thoroughly its approval of the program's mechamism to ensure that the funds made available by the tax exemption were used only for secular purposes. Instead, it asserted, as the Allen Court did, that the mecharnism did not require enough nonitoring by the government to constitute government entanglement with rehigion. ${ }^{95}$ The majority concluded that any monitoring that did occur, such as screening textbooks to select those that qualified for the tax exemption, was no inore problematic than the monitoring required in Allen. ${ }^{96}$ Accordingly, the majority's reasoning exhibits the same inconsistencies that were present in the Allen Court's holding. ${ }^{97}$

Emerging from these cases is a collection of results that are difficult

90. Id. at 397.

91. Arguably, benefits extended only to private schools affect religious schools disproportionately. This argument therefore suggests that if the government gives a greater quantum of aid to religious groups than to nonreligious groups, then the effect is unconstitutional. It slifts the inquiry from whether religious groups benefit at all to whether religious groups benefit more than nonreligious ones. In implicitly relying on this argument, however, Mueller never states low much more religious groups must benefit than nonreligious groups before the effect becomes unconstitutional. The Court appears to suggest only that it will probably find an unconstitutional effect of advancing religion in cases where the benefit to religion is disproportionate, as it arguably was in Mueller. Thus, disproportion becomes merely a red flag: it does not automatically make government action unconstitutional where such action otherwise would be permissible. It is not, per se, a basis for a finding of unconstitutionality. The inquiry into effect remains fact-specific, but the Court lias not specified low or how much disproportion slifts the balance against the government action's validity.

92. 463 U.S. at 399.

93. Id. at 398.

94. Id. at 399. Justice Marshall, in his dissent, pointed out this concession by the majority. Id. at 412 (Marslall, J., dissenting).

95. 463 U.S. at 403.

96. Id.

97. See supra text aecompanying notes 23-32. 
to reconcile under any conceivable legal standard. As Justice Rehnquist pointed out in his dissent in Wallace v. Jaffree: ${ }^{98}$

[A] State may lend to parochial school children geography textbooks that contam niaps of the United States, but the State may not lend maps of the United States for use in geography class. A State niay lend textbooks on American colonial history, but it may not lend a film on George Washington, or a film projector to show it in history class. A State niay lend classroonı workbooks, but may not lend workbooks in which the parochial school children write, thus rendering them nonreusable. A State may pay for bus transportation to religious schools but niay not pay for bus transportation from the parochial scliool to the public zoo or natural history museuin for a field trip. A State may pay for diagnostic services conducted in the parochial school but therapeutic services must be given in a different building; speech and hearing "services" conducted by the State inside the sectarian school are forbidden, but the State may conduct speecl and hearing diagnostic testing inside the sectarian scliool. Exceptional parochial scliool students niay receive counseling, but it must take place outside of the parochial school, such as in a trailer parked down the street. A State niay give casli to a parochial schiool to pay for the administration of state-written tests and state-ordered reporting services, but it niay not provide funds for teacher-prepared tests on secular subjects. ${ }^{99}$

\section{Noneducational Setting}

Cases outside of the educational context exhibit equally unconvincing rationales and yield similarly inconsistent results.

\section{a. Official Acknowledgment of Religion: State-Sponsored Christmas Displays}

Establishment Clause challenges to state-sponsored Christmas displays seem especially difficult for the Court. In Lynch v. Donnelly, ${ }^{100}$ the Court held that a city-funded Christmas display, which included a crèclie, did not violate the Establishment Clause. ${ }^{101}$ In reacling this conclusion, the Court eniployed the three-prong test first announced in

98. 472 U.S. 38 (1985).

99. Id. at 110-11 (Rehnquist, J., dissenting) (citations and footnotes omitted).

100. 465 U.S. 668 (1984).

101. Id. at 687 . While the display was city-funded, it was located on land owned by a private nonprofit organization. Id. The discussion here does not address the Court's decision in Allegheny v. $A C L U, 492$ U.S. 573 (1989), because that case involved a religious display that was on public land but not funded by the government. That case is discussed with the other cases involving noneconomic assistance to religion. See infra text aecompanying notes 197-215. 
Lemon v. Kurtzman. ${ }^{102}$

After noting that the display had a plausible secular purposedepicting the historical origins of a significant national holiday ${ }^{103}$ - the Lynch Court considered whether the effect of the display was permissible. While the Court conceded that the display may have advanced rehigion "in a sense," 104 it declared that the benefit conferred on religion by the display was no greater than the benefits approved in Allen and Everson. ${ }^{105}$ This reasoning suggests that impermissible effect turns on the degree of benefit conferred on religion.

The Everson Court, however, did not base its holding on the degree of benefit to religion, ${ }^{106}$ and the degree of harm is an unconvincing basis for both the Everson and the Allen holdings. Finally, the Court concluded that state funding of the display created no impermissible entangleinent. ${ }^{107}$ It noted that church authorities had no influence on the design or content of the display. ${ }^{108}$ Further, the amount of tax inoney used to inamtain the display was neghigible. ${ }^{109}$

While Lynch's holding is noteworthy, Justice O'Connor's concurrence is more significant because it introduces an alternative to the Lemon test. According to O'Connor:

The purpose prong of the Lemon test asks whether government's actual purpose is to endorse or disapprove of religion. The effect prong asks whether, irrespective of government's actual purpose, the practice under review in fact conveys a message of endorseinent or disapproval. An affirmative answer to either question should render the challenged practice invalid. ${ }^{110}$

Justice O'Connor explained how a statement is determined to be an endorsement: "The ineaning of a statement to its audience depends both on the intention of the speaker and on the 'objective' ineaning of the statement in the commumity."111

Applying her test to the facts of the case, Justice O'Connor concluded first that the government did not intend to endorse

102. See 465 U.S. at $681-85$.

103. Id. at $680-81$.

104. Id. at 683 .

105. Id. at $681-82$.

106. The Everson Court based its holding on the fact that the program benefited religious and nonreligious educational institutions alike. Everson v. Board of Educ., 330 U.S. 1, 17 (1947). In fact, it insisted that the "wall [between church and state] unust be kept high and impregnable. We could not approve the slightest breach." Id. at 18. The "slightest breach " language inplies that if the type of assistance to religion is impermissible, then the degree of aid becomes irrelevant.

107. Lynch, 465 U.S. at 684.

108. Id.

109. Id.

110. Id. at 690 (O'Connor, J., concurring).

111. Id. 
Christianity. ${ }^{112}$ Second, she concluded that the display did not have the effect of endorsing Christianity. ${ }^{113}$ She reasoned that because no one would seriously contend that the niere celebration of Christmas endorses Christiamity, a symbol depicting the rehgious origins of that primarily secular holiday does not endorse the religion from which the holiday arose. ${ }^{114}$ As Justice Brennan pointed out, however, it does not follow that because the traditional holiday of Christmas does not endorse Christianity, symbols representing the distinctively religious components of the holiday do not endorse Christianity. ${ }^{115}$

Justice O'Connor's reasoning is puzzling, as is her reliance in this context on a symbolic inquiry. Since the city used tax dollars to buy and inaintain the display, ${ }^{116}$ at least one aspect of the benefit to religion in this case-the money spent-could be quantified. Therefore, this is not a case where it would be difficult to define "advancement."117 Indeed, the Court readily admitted that the display advanced a rehigion. ${ }^{118}$ Thus, Lynch could have been resolved under the existing line of cases involving state expenditures for the benefit of religious activities and institutions. It seems probable, then, that it was the Court's inability to apply Lemon consistently to cases involving economic aid to religion-not the inherent ambiguity of the word "advanceinent"-that created what Justice O'Connor perceived as a need for a niodified test.

The introduction of the endorsenient test in Lynch reflects how confusing the Court's Establishment Clause reasoning has become. Even if a new test was necessary to accommodate activities like the one upheld in Lynch, the use of endorsement as the touchstone of impermissible estabhishment is particularly unsuitable because the concept of endorsement seeins to derive its ineaning from the symbohic content of objects or actions. The Court's cases indicate that soine unspecified degree of assistance to religion is constitutionally tolerable. If endorsement were

112. Id. at 691. Justice $O^{\prime}$ Connor cited no evidence for this conclusion. She merely stated that "It]he evident purpose of including the crèche in the larger display was ... celebration of the public holiday through its traditional symbols." $I d$.

113. Id. at $692-93$.

114. Id. at 692 .

115. Id. at 709-10 (Brennan, J., dissenting).

116. 465 U.S. at 671.

117. The key problem in the cases involving financial assistance to religion is in deciding how much "advancement" is too much or under what circumstances "advancement" will be tolerated to serve some overriding secular purpose. The necessity of defining "advancement" arises where the benefit to rehigion is unquantifiable and must, therefore, be assessed by qualitative criteria. Of course, the Court may have believed that the amount of financial support was so low in this case as to be negligible and that it could therefore proceed to examine other ways in which religion might be helped impermissibly. However, the Court neglected to specify precisely what amount of financial support would be low enough to justify disregarding it.

118. Lynch, 465 U.S. at 682 . The Court found, though, that the display's effect " 'merely happens to coincide or harmonize with the tenets of some ... religions.'" Id. (emphasis added) (quoting McGowan v. Maryland, 366 U.S. 420, 442 (1961)). 
the key to Establishment Clause cases, however, it would undoubtedly be easier to defend the conclusion that a crèche impermissibly appears to advance religion by endorsing Christianity than the conclusion that it impermissibly advances Christianity in fact. If anything, then, the endorseinent test, if applied scrupulously, is potentially stricter than the effects prong of the Lemon test as it was apphed by the Court before Lynch was decided.

\section{b. Granting Unemployment Benefits to Accommodate Religious Beliefs}

In Sherbert $v$. Verner, ${ }^{119}$ the Court held that the Free Exercise Clause of the First Amendinent ${ }^{120}$ required the state to provide unemployment compensation to a woman who resigned froin a job that required her to work on her Sabbath day. The Court reasoned that Everson prohibited excluding individuals on the basis of their religion from receiving government benefits. ${ }^{121}$ However, the Court did not address the conflict between the provision of tax-funded benefits to the plaintiff in Sherbert and Everson's prohibition of using tax dollars to benefit religion.

The Court's analysis was similarly unsatisfying in Thomas $v$. Review Board ${ }^{122}$ and Hobbie v. Unemployment Appeals Commission. ${ }^{123}$ In both cases, the Court upheld the payment of unemployment coinpensation to einployees who could not work for religious reasons. In Thomas, the Court supported its holding simply by citing Sherbert. ${ }^{124}$ The Hobbie Court employed the saine citation and added only a single sentence asserting that its holding did not foster excessive entanglement of the state with religion. ${ }^{125}$

Because these cases focused primarily on the Free Exercise Clause, the Court largely disregarded the Establishment Clause implications of the government assistance at issue in the cases. These fact patterns, however, raise the saine Establishment Clause concerns that any governinent economic assistance to rehigion raises. Thus, the Court's failure to analyze these situations under tlie Establishment Clause hightights its inability to apply a unified set of principles to the religion cases both in classifying the cases by legal question and in deciding them consistently.

119. 374 U.S. 398 (1963).

120. "Congress shall make no law ... prohibiting the free exercise [of religion] . . ." U.S. CONST. amend. I.

121. Sherbert, 374 U.S. at 410.

122. 450 U.S. 707 (1981) (holding that the Free Exercise Clause required unemployment compensation for a man who was required by his former employer to inanufacture weapons, an activity that violated his religious beliefs).

123. 480 U.S. 136 (1987) (holding that the Free Exercise Clause required unemployment compensation for a woman who resigned from her job on religious grounds, even though her conversion occurred after her employment began).

124. Thomas, 450 U.S. at $719-20$.

125. Hobbie, 480 U.S. at 145. 


\section{c. Tax Exemptions for Various Religious Institutions and Activities}

The decisions considering the constitutionality of tax exemptions for rehioious institutions are equally puzzling. In Walz v. Tax Commission, ${ }^{126}$ the Court approved a tax exemption for religious organizations' properties that were used only for religious purposes. The Court found that the purpose of the exemption was legitimately secnlar and that the entanglement of government with religion was not excessive. ${ }^{127}$ It reasoned that the entanglement would have been greater if the government did not provide the exemption because the government would then liave to value church properties for tax purposes. ${ }^{128}$

The Walz Court seemed to dismiss the possibility of any impermissible advancement of religion. Instead, it employed the familiar, but artificial, distinction between direct and indirect assistance ${ }^{129}$ and assumed that because a tax exemption does not imvolve direct money grants, it is less offensive to the Establishment Clause. ${ }^{130}$ The Court also noted that because the tax exemptions do not transform churches into "arms of the state," there is "no genuine nexus between tax exemption and establishment of religion." 131 The Walz decision, then, not only defied Everson's sweeping prohibition, but it also avoided applying the advancement prong of what eventually became the Lemon test.

In contrast, the Court in Texas Monthly, Inc. v. Bullock ${ }^{132}$ struck down a sales tax exemption for periodicals published or distributed by religious institutions and consisting entirely of writings that either teach or are sacred to a rehigious faith. ${ }^{133}$ The plurality used the fact that the exemption affected only religious activities as evidence of an improper purpose to advance retigion and as conclusive proof of the impermissible effect of advancing religion. ${ }^{134}$

The Bullock plurality distinguished Walz by noting that in Walz, unlike Bullock, a truly secular purpose was the basis for similar benefits for religious and nonreligious organizations. ${ }^{135}$ A distinction based on this criterion, however, iguores the sweeping Everson prohibition against financial assistance to religion. Further, Walz was not based on the fact that nonrehgious and religious groups alike were exempted; rather, it was

\footnotetext{
126. 397 U.S. 664 (1970).

127. Id, at $672-73$.

128. Id, at 674.

129. See supra text accompanying notes $48-49$, $92-94$ (discussing the Court's attempts to distinguish direct and indirect assistance).

130. Waln, 397 U.S. at 675.

131. Id.

132. 489 U.S. 1 (1989) (plurality opinion).

133. Id. at 5 .

134. Id. at 15-17. The Court's primary focus in this discussion was that the exemption benefited only religious organizations. This narrowness was apparently sufficient to find the scheme uncoustitutional.
}

135. Id. at 12-13. 
based largely on the long history of giving tax exemptions to churches and the perceived inconvenience of ending this tradition. ${ }^{136}$

Because states have long granted tax exemptions to rehious organizations in general and churches in particular, the Court has avoided striking these exemptions down. Where such exemptions are at issue, the Court sidesteps Estabhshment Clause precedent that would appear to prohibit the exemptions and rehes instead on questionable distinctions such as whether the inoney is provided to individual participants in religious activities or to the rehgious institutions theinselves, and whether nonreligious institutions are benefitted as much as religious institutions. Although these distinctions might make sense intuitively, it is not clear why they should justify the Court's disregard of prior Establishment Clause cases that forbid this kind of economic assistance altogether.

\section{B. Noneconomic Assistance to Religion}

Although the cases involving noneconomic benefits to religion are more consistent than those involving economic benefits, these decisions are still far from coherent.

\section{Educational Setting: Religion in the Public Schools \\ a. Released Time Programs}

The first major case involving noneconomic benefits to religion was McCollum v. Board of Education. ${ }^{137}$ In McCollum, the Court invalidated a state program in which privately employed religious teachers were allowed to offer religious instruction to interested students in public school buildimgs during normal school hours. ${ }^{138}$ The Court found that the close cooperation between religious and public school authorities and the fact that the religious instruction occurred on tax-supported property and was facilitated by tax-supported administrators created an impermissible benefit to religion. ${ }^{139}$

Only four years after McCollum, however, the Court deviated from this separationist stance. In Zorach $v$. Clauson, ${ }^{140}$ the Court considered the constitutionality of a New York "released time" program that allowed public schools to release students during the school day so that they could attend rehgious activities off school grounds. ${ }^{141}$ Although only the location of the religious instruction distinguished this program from the one considered in McCollum, the Court held that the Zorach program was constitutional.

136. Walz v. Tax Comm'n, 397 U.S. 664, $677-78$ (1970).

137. 333 U.S. 203 (1948).

138. Id. at 205.

139. Id. at 209-12.

140. 343 U.S. 306 (1952).

141. Id. at 308 . 
The Court gave only two reasons for its decision in Zorach. First, there was no evidence that the students were coerced in any way to attend the rehigious classes. ${ }^{142}$ Second, the Court believed that if this program were illegal, then Thanksgiving Day proclamations, prayers in the legislature, and provision of basic fire or police protection to religious institutions would be invalid. ${ }^{143}$ The Court did not explam why these other practices do not violate the Establishment Clause. It seened simply to assuine that they were valid.

This reasoning, however, is flawed. As Justice Black noted in his dissent, the McCollum liolding rested not only on the fact that school facilities were used for religious instruction, but also on the fact that public school einployees facilitated religious indoctrination by stopping classes at the appropriate time to release sonie students and inonitoring the students' 1noveinent to and fron rehgious activities. ${ }^{144}$ The holdings of McCollum and Zorach are consistent only if constitutionality in this context depends solely on the degree of involvenient between church and state. However, the Court inade no attempt to specify low inuch involvement is constitutionally impermissible. These cases deinonstrate that altliough the Court acknowledges precedent in its decisions, it disregards that precedent in order to uphold traditional American educational practices whose abolition would be inconvenient.

\section{b. Religious Activities Led by Public School Teachers}

In Engel v. Vitale, ${ }^{145}$ the Court invalidated the practice of reciting daily a short prayer in public scloool classroonis. ${ }^{146}$ The Court quickly concluded that the purpose of the activity was solely religious. ${ }^{147}$ It also noted the unmistakably religious character of the activity. ${ }^{148}$ The Court did not, however, comment on whether the activity liad an impermissible effect. Apparently, the Court deeined it obvious that an activity with a solely religious purpose and an unmistakably religious cliaracter would liave the effect of advancing religion.

In School District v. Schempp, ${ }^{149}$ the Court reached a similar resnlt, though with greater difficulty. Schempp involved progranis that inan-

142. Id. at 311.

143. Id. at $312-13$.

144. Id. at 316 (Black, J., dissenting).

145. 370 U.S. 421 (1962).

146. The prayer read as follows: "Almighty God, we acknowledge our dependence upon Thee, and we beg Thy blessings upon us, our parents, our teachers and onr Country." Id. at 422.

147. Id. at 425 ("[P]etitioners contend ... that ... [the] prayer was composed by governmental officials as a part of a governmental program to further religious beliefs. ... We agree with that contention ....").

148. Id. at 424-25 ("There can . . be no doubt that [a] program of daily classroom invocation of God's blessings ... is a religious activity. It is a solemn avowal of divine faith and supplication for the blessings of the Almighty. The nature of such a prayer has always been religious .....").

149. 374 U.S. 203 (1963). 
dated the reading, without comment, of several Bible verses at the opening of each public school day. ${ }^{150}$ The programs allowed students to be excused from the readimg upon request from their parents. ${ }^{151}$ Although the school boards advanced plausible secular justifications for the programs, ${ }^{152}$ the Court rejected those justifications and focused instead on the rehigious character of the imstrument used-the Bible-to support its conclusion that the purpose of the activity could not possibly have been secular. ${ }^{153}$ Accordimgly, it did not articulate what undoubtedly would have been its conclusion about the effect of the activity: that it impermissibly benefitted rehigion. ${ }^{154}$

The major inconsistency between the Court's approaches in Schempp and Zorach appears not in the results reached, but rather in the rationales einployed. In Schempp, the school boards argued that the religious practice should be upheld because it resulted ouly in "relatively minor encroachments on the First Amendment." 155 The Court rejected that argument with the following metaphor: "The breach of neutrality that is today a trickling stream may all too soon become a raging torrent ...."156 This language is striking in view of the fact that the Zorach Court imphicitly based its holding on the degree of harm, or infringement, caused by the released time program. ${ }^{157}$ Unless Zorach is viewed as an aberration in the Supreme Court's treatment of rehigion in the pubhic schools, there appears to be no common thread that unifies the Court's decisions im this area.

The Court just as readily struck down an Alabama law requiring moments of silence in pubhic schools for voluntary prayer and/or meditation in Wallace $v$. Jaffree. ${ }^{158}$ Although moments of silence are arguably less rehgious in character than Bible readings or prayer recitations, the Court determined that the statute was motivated by a solely religious purpose. ${ }^{159}$ Accordingly, the law failed the purpose prong of the Lemon test. Again, the Court did not comment on why other activities-such as the released time program at issue im Zorach-reinained valid even

150. Id. at $205,211$.

151. Id. at 205, 211-12.

152. Id. at 223 (noting that the justifications included "the promotion of moral values, the contradiction to the materialistic trends of our times, the perpetuation of our institutions and the teaching of literature").

153. Id. at 224 .

154. The Court did note that "[s]urely the place of the Bible as an instrument of religion cannot be gainsaid, and the State's recognition of the pervading religious character of the ceremony is evident . . . " Id. (emphasis added). This language suggests that the inquiry into purpose was unnecessary because the activity would have clearly been invalidated on effects grounds.

155. Id. at 225 .

156. Id.

157. See supra text accompanying note 144.

158. 472 U.S. 38 (1985).

159. Id. at 56-61 (reviewing the statute's legislative history). 
though they are clearly motivated by rehgious purposes and potentially advance rehigion more than do moments of silence.

The Court has thus been unable to decide whether rehioious purpose alone imvalidates religious activities led by public school teachers or officials. Further, it has been unable to decide whether such activities are invalid if they create any religious effect at all or only if they create some unspecified intolerable degree of rehigious effect. These deficiencies render this small group of cases imternally inconsistent and inconsistent with the broader body of Establishment Clause decisions.

\section{c. Religious Objects in the Classroom}

Stone v. Graham ${ }^{160}$ involved a Kentucky statute requiring that a copy of the Ten Commandments, purchased with private funds, be posted in every public school classroom. ${ }^{161}$ Not surprisingly, the Court invalidated the statute. Its reasoning, however, consisted simply of the conclusion that the purpose of the statute was "plainly rehgious."162

In dissent, Justice Rehnquist criticized the majority for its refusal to accept the Legislature's articulated secular purpose. ${ }^{163}$ If Rehnquist is correct and the Legislature did articulate a plausible secular purpose, then the Court's rejection of that asserted purpose is at odds with its approach im previous cases, where legislatures' express motivations were crucial to purpose determinations. ${ }^{164}$ Unfortunately, though, it is unclear whether Rehnquist was correct because he did not describe that asserted purpose. Further, even if the purpose had been secular, the law probably would have been invalidated anyway because it impermissibly benefitted rehgion. ${ }^{165}$

This case, then, suggests that the Court cannot decide whether to accept a legislature's articulated justification for a challenged practice. More broadly, the Court seems to find a religious purpose when it wants to strike down a state practice and to find none when it does not. There is no apparent distimction between legislative intent in the cases where practices have been upheld and intent im those where practices have been struck down.

160. 449 U.S. 39 (1980) (per curiam).

161. Id. at 39.

162. Id. at 41 .

163. Id. at 43-45 (Rehnquist, J., dissenting).

164. See, e.g., Board of Educ. v. Allen, 392 U.S. 236, 243 (1968) (observing that the Legislature's "express purpose" was the "furtherance of . . . educational opportunities").

165. As the Court observed, "If the posted copies of the Ten Commandinents are to have any effect at all, it will be to induce the schoolchildren to read, meditate upon, perhaps to venerate and obey, the Cominandinents." Stone, 449 U.S. at 42. 


\section{d. Religious vs. Secular Content of the Public School Curriculum}

A series of cases dealing with the content of the public school curriculum offers additional evidence of the inconsistencies in the Court's Establishment Clause jurisprudence. Typically, the laws at issue in these cases either forbid public schools from teaching evolution or require that they teach the theories of creationism and evolution simultaneously. Although these laws do not mandate overtly rehigious activities or displays in public school classrooms, the Court seems particularly willing to strike them down. The likely reason for the Court's attitude is that these laws are invariably motivated by a rehigious purpose.

In Epperson v. Arkansas, ${ }^{166}$ for example, the Court invalidated an Arkansas statute forbidding public schools from teaching the theory that "man evolved from other species of life."167 Citmg Schempp, the Court noted that a law with the purpose or effect of advancing religion must be imvalidated. ${ }^{168}$ According to the Epperson Court, there was "no doubt that Arkansas has sought to prevent its teachers from discussing the theory of evolution because it is contrary to the belief of some that the Book of Genesis must be the exclusive source of doctrine as to the origin of man."169

By focusing exclusively on purpose, the Epperson Court deviated from earher Supreme Court decisions deahing with rehigion in the public schools. For example, the Zorach Court focused only on the effect of the released time program. ${ }^{170}$ It is unclear whether the Epperson Court viewed Zorach as consistent with its own holding. If the Court did in fact view the two decisions as inconsistent, it declined to state directly that a program like the one in Zorach would be invalid under the new purpose/effect test announced in Schempp.

Similarly, in Edwards v. Aguillard, ${ }^{171}$ the Court invalidated a Louisiana law that barred public schools from teaching the theory of evolution unless they also taught "creation science."172 Although the Legislature argued that the law served a legitimate secular purpose-the advancement of academic freedom-the Court found that the law's purpose was to advance religion and concluded that the statute was there-

166. 393 U.S. 97 (1968).

167. Id. at 98 .

168. Id. at 107 (" "[W] hat are the purpose and the primary effect of the enactment? If either is the advancement or inhibition of rehigion then the enactment exceeds the scope of legislative power as circumscribed by the Constitution." " (quoting School Dist. v. Schempp, 374 U.S. 203, 222 (1963))).

169. Id.

170. Zorach v. Clauson, 343 U.S. 306, 311-14 (1952). The Zorach Court focused on the extent to which the challenged practice coerced children to participate in religious activities. Coercive effect in this context means the same thing as religious effect. See supra text aceompanying notes 140-42.

171. 482 U.S. 578 (1987).

172. Id. at 581 (citing LA. ReV. Stat. ANN. $\$ 17: 286.4$ A (West 1982)). 
fore unconstitutional. ${ }^{173}$ Accordingly, the Court noted that it was unnecessary to decide whether the effect of the law was to advance religion. ${ }^{174}$ This reasoning is similar to that in Epperson. Also, the Aguillard Court's failure to consider the effect of the challenged law appears to be inconsistent with the approach in Zorach.

\section{e. Equal Access for Religious Organizations to Public School Facilities}

The Court's preoccupation with purpose continued in two cases involving the right of religious organizations to ineet on public school grounds. Although the results are defensible, the Court's reasoning is problematic.

In Widmar v. Vincent, ${ }^{175}$ the Court held that public universities that make their facilities available to student groups generally must also make those facilities available to religious organizations for religious purposes. Although the Court based its decision primarily on free speech grounds, ${ }^{176}$ it also indicated that the policy did not violate the Establishment Clause. ${ }^{177}$

The Court offered three reasons for its Establishment Clause holding. First, the availability of facilities to religious groups serves the legitimate secular purposes of providing a forum where students can exchange ideas, and of not discriminatimg against particular groups on the basis of the content of their speech. ${ }^{178}$ Second, the open-forum policy contemplated by the Court would not advance religion by conferring "any imprimatur of state approval on religious sects or practices."179 Finally, the Court believed that the open-forum policy would not impermissibly advance religion in any sense because "the forum [would be] available to a broad class of nonreligious as well as religious speakers." 180

The Court cited Wolman and Nyquist as support for this last propo-

173. Id. at 581, 596-97. Justice Brennan, writing for the majority, was unwilling to defer to the Legislature's statement of purpose because he suspected that it was a "sham." Id. at 587. He reached this conclusion by analyzing the extent to which the statute actually achieved the stated objective of increasing academic freedom. Id. at 587-89. He concluded that it actually decreased freedom by restricting the range of topics that teachers could discuss in class. Id. at 588-89. Brennan either assumed or determined from a source not identifiable in the opinion that "academic freedom" means freedom for the teacher. Had he viewed "academic freedom" in terms of the range of topics to which the public school students were exposed, he might have reached a different conclusion.

174. Id. at 585 ("If the law was enacted for the purpose of endorsing religion, "no consideration of the second or third criteria [of Lemon] is necessary." ") (alteration in original) (quoting Wallace v. Jaffree, 472 U.S. 38,56 (1985)).

175. 454 U.S. 263 (1981).

176. Id. at 273 ("The question is not whether the creation of a religious foruin would violate the Establishment Clause. The Uinversity has opened its facilities for use by student groups, and the question is whether it can now exclude groups because of the content of their speech.").

177. Id. at 271-75.

178. Id. at 271-72 \& n.10.

179. Id. at 274.

180. Id. 
sition. ${ }^{181}$ The Court failed, however, to cite the one financial aid case where benefits were inade available to all institutions: Aguilar $v$. Felton. ${ }^{182}$ It also failed to explain why, if the broad availability of a benefit is such an essential criterion for identifying secular effect, that availability did not save the Aguilar scheme. If the determination of whether advancement is the "primary effect" turns on the proportion of the benefit that goes to rehgion, the Aguilar program should have survived the effects analysis. ${ }^{183}$

\section{Noneducational Setting \\ a. Official Acknowledgment of Religion}

The Court has been reluctant to mvalidate any practice that it classifies as a mere acknowledgment of religion even when the purpose or effect of the activity at issue may be to advance rehigion substantially. In these cases, the Court appears to be motivated more by an awareness of the historical and cultural significance of these activities than by any logical distmction between these actions and the actions at issue in the cases already discussed here.

In McGowan v. Maryland, ${ }^{184}$ for example, the Court upheld laws proscribing all commercial activity on Sundays. It found that the purpose of such laws was not to "facilitate and encourage church attendance."185 Although it conceded that these laws may, at one time, have been motivated by rehigious concerns, the Court pointed out that the laws liave been justified on secular grounds such as the liealth and safety of workers ${ }^{186}$ and that the current versions of the Sunday closing laws were probably motivated by these secular concerns. ${ }^{187}$ While the Court con-

181. Id. (citing Wolman v. Walter, 433 U.S. 229, 240-41 (1977); Committee for Pub. Educ. \& Religious Liberty v. Nyquist, 413 U.S. 756, 781-82 \& n.38 (1973)).

182. 473 U.S. 402 (1985). Recall that in Aguilar, the government made funds available to local educational institutions to meet the needs of low-income clildren. See supra text accompanying notes 73-74.

183. See also Board of Educ. v. Mergens, 496 U.S. 226 (1990) (requiring secondary scliools to provide the type of equal access required in Widmar and employing reasoning similar to Widmar's). In Mergens, a group of high school students was denied permission by the school board to conduct religious meetings on public school facilities after school hours. They sued the school district for a violation of the Free Exercise Clause. The Court lield that a federal statute required the school board to grant "equal access" to the religious group if it allowed nonreligious groups to use these facilities for meetings. Id. at 247. The Court also held that a policy of equal access would not violate the Establishment Clause. Id. at 248. Although allowing religious groups to meet on school property would assist religion, students were not likely to perceive a "symbolic link between [tlie scliool] and religion." "Id. at 250 (quoting School Dist. v. Ball, 473 U.S. 373, 385 (1985), overruled by Bowen v. Kendrick, 487 U.S. 589 (1988)).

184. 366 U.S. 420 (1961).

185. Id. at 431 .

186. Id. at $434-35$.

187. Id. at 435 ("Throughout the years, state legislatures have modified, deleted from and added to their Sunday statutes. . . . Thus have Sunday laws evolved from the wholly religious sanctions that originally were enacted."). 
ceded that these secular purposes could be fulfilled by providing for rest on any day of the week, ${ }^{188}$ it noted that another purpose of the laws was to facilitate family and community interaction, which can only occur if people are free from work commitments at the same time. ${ }^{189}$ It went on to note that because people are accustorned to resting on Sunday, it would be "detrimental to the general welfare" to demand that the day be changed. 190

While the McGowan Court convincingly argued that there was a secular purpose for the Sunday closing laws, it failed to address the question of impermissible effect. The Court may have beheved that the historical significance of the tradition and the extreme inconvenience of changing the day of rest to another day of the week rendered the laws valid. If so, then the Court was directly at odds with its declaration im a subsequent case that, "[s]tanding alone, historical patterns carmot justify contemporary violations of constitutional guarantees."191 Further, the McGowan decision defies the holdings of cases striking down religious activities in public schools-activities that were also practiced for many decades before being challenged. If the Court's decision was not based on historical tradition, it is unclear why the Court determined that the benefit conferred on Christianity by the Sunday closing laws was permissible in liglit of its precedents. ${ }^{192}$

Similarly, in Marsh v. Chambers ${ }^{193}$ the Court allowed a substantial advancement of rehion in deference to historical practice. Marsh upheld Nebraska's practice of beginning state legislative sessions with prayers offered by chaplains chosen by the Legislature and paid with public funds. The Court did not attempt to characterize the purpose of the activity as secular; such an attempt would have mevitably failed. ${ }^{194}$

188. Id. at 450 ("It is true that if the State's interest were simply to provide for its citizens a periodic respite from work, a regulation demanding that everyone rest one day in seven, leaving the choice of the day to the individual, would suffice.").

189. Id. at $450-51$.

190. Id. at 452 .

191. Marsh v. Chambers, 463 U.S. 783, 790 (1983) (holding legislative prayer constitutional).

192. True, the secular effect could be realized whether or not religion was benefitted. See McGowan, 366 U.S. at 435-37. However, the precedents at the time of the McGowan decision did not offer this as a basis for distinguishing permissible and impermissible state action. The definitive statement of the law at that time was Everson's sweeping pronouncement. See supra text accompanying note 18 .

193. 463 U.S. 783 (1983).

194. As Justice Brennan noted in his dissent:

That the "purpose" of legislative prayer is pre-eminently religious rather than seeular seems to me to be self-evident. "To invoke Divine guidance on a public body entrusted with making the laws" is nothing but a religious act. Moreover, whatever secular functions legislative prayer might play-formaliy opeining the legislative session, getting the members of the body to quiet down, and imbuing them with a sense of seriousness and high purpose-could so plainly be performed in a purely nonreligious fashion that to claim a secular purpose for the prayer is an insult to the perfeetly honorable individuals who instituted and continue the practice.

Id. at 797-98 (Brennan, J., dissenting) (citation oinitted) (quoting 463 U.S. at 792). 
Nor did the Marsh Court attempt to deny that the practice might advance the interests of religion generally. It said merely that it could not "perceive any suggestion that choosing a clergyinan of one denomination advances the beliefs of a particular church."195 As Justice Brennan correctly noted in dissent, the Court made "no pretense of subjecting Nebraska's practice of legislative prayer to any of the formal 'tests' that have traditionally structured our inquiry under the Establishment Clause." 196

Of the cases involving official acknowledgment of religion, perhaps County of Allegheny v. $A C L U^{197}$ inost clearly shows the Court's inability to agree on a single standard or to reconcile earlier and more recent Establishment Clause decisions. In Allegheny, the county allowed two privately sponsored Christmas displays on county property. One display consisted of a crèclie located on the steps of the county courthouse; the second display consisted of a Hanukkah menorall, a Christmas tree, and a sign saluting liberty in front of the City-County Building. ${ }^{198}$

The Allegheny majority exphicitly adopted and applied Justice O'Connor's endorsement test, as formulated in Lynch. ${ }^{199}$ In finding the display of the crèclie unconstitutional, the Court focused exclusively on the effect of the display. It concluded that the character of the display was unmistakably Christian ${ }^{200}$ and that "no viewer could reasonably think that it occupies this location without the support and approval of the government."201

In responding to Justice Kennedy's criticisms of this holding, the Allegheny majority made some questionable assertions. It clained that Marsh did not rest merely on the historical significance of legislative prayer. ${ }^{202}$ Unfortunately, the Court pointed to no other reason for the Marsh decision, but noted simply that the Marsh prayer was nondenominational. ${ }^{203}$ If, however, this reference implies that favoring all religions equally is permissible, the Allegheny majority broke witl Everson's prohibition on any aid to religion ${ }^{204}$ and with the effects prong of the Lemon test, which apparently prohibits even the equal advancement of all

195. 463 U.S. at 793 (emphasis added). The Marsh Court admitted, however, that by permitting the practice of legislative prayers it was acknowledging "beliefs widely held among the people of this country." Id. at 792.

196. Id. at 796 (Brennan, J., dissentimg).

197. 492 U.S. 573 (1989).

198. Id. at 578 (plurality opinion).

199. See supra text accompanying notes 110-11.

200. Allegheny, 492 U.S. at 598.

201. Id. at 599-600.

202. Id. at 603 .

203. Id. The Marsh Court described the challenged legislative prayers as "in the JudeoChristian tradition." Marsh v. Chambers, 463 U.S. 783, 793 (1983). Explicit Christian references were removed in response to a Jewish legislator's complaint. Id. at 793 n.14.

204. See supra text accompanying note 18. 
religions. ${ }^{205}$

Unable to reconcile Marsh with its invalidation of the crèche, the Justices then considered the validity of the second display. Justice Blackmun concluded that this display was constitutional, suggesting that the tree and the menorali represented merely the secular aspects of two separate holidays. ${ }^{206}$ Although Blackmun admitted that the menorall is a religious syinbol, ${ }^{207}$ he focused on the tree, which was the largest item in the display. Because the tree is a secular syinbol, Blackmun felt that it was plausible to view the entire display as secular and not as an endorsement of either the Jewish faith alone or the Jewish and Christian faiths together. ${ }^{208}$

Although Justice O'Connor concurred with the majority's judginent, her apphication of the endorsement test was slightly different. Instead of viewing the menorah and Christmas tree display as entirely secular, she described the display as a permissible depiction of "plurahism and freedom of behef during the holiday season." 209 She accepted that the menorall retained its religious significance even when placed next to a secular symbol like the Christmas tree but argued that because it was next to other, non-Jewish symbols, the menorah did not endorse Judaism. ${ }^{210}$ For O'Comior, the acknowledgment of more than one behef system was crucial to the characterization of the display as an endorsement of rehigious pluralism. She did not explain, however, why juxtaposed Jewish and secular symbols can convey an acceptable message of "freedom to choose one's own beliefs"211 while Jewish and Christian symbols together presumably would not. ${ }^{212}$

Justice Kennedy rejected the endorsement test entirely and proposed that a violation of the Establishment Clause should depend on a showing of some kind of coercion. ${ }^{213} \mathrm{He}$ indicated that under a coer-

205. See Lemon v. Kurtzman, 403 U.S. 602, 612 (1971) (declaring that the Establishment Clause prohibits active state involvement in religious activity).

206. Allegheny, 492 U.S. at 617-18 (plurality opinion).

207. Id. at 613 .

208. Id. at 616-18.

209. Id. at 635 (O'Connor, J., concurring in part and concurring in the judgment).

210. Id.

211. Id. at 634.

212. In dissent, Justice Brennan noted:

[T] he pluralism that Justice O'Connor perceives . . . arises from the recognition that there are many ways to celebrate the "winter holiday season." But winter is "the holiday season" to Christians, not to Jews, and the imphicit message that it, rather than autumn, is the time for pluralism sends an impermissible signal that only holidays stemming from Christianity, not those arising from other religions, favorably dispose the government towards "pluralism."

Id. at $640 \mathrm{n.*}$ (Brennan, J., concurring in part and dissenting in part) (citation omitted). Although it is questionable whether the average observer of the display would engage in Brennan's depth of analysis, these remarks highlight some of the theoretical shortcomings of Justice O'Connor's use of the notion of pluralism to justify her conclusions.

213. Id. at $659-60$ (Kennedy, J., concurring in the judgment in part and dissenting in part). 
cion-based standard, both displays were valid. ${ }^{214}$ Remarkably, Kennedy asserted that this test was consistent with precedent $t^{215}$ even though prior decisions explicitly refused to make violations contingent on coercion. ${ }^{216}$

The Allegheny opinions reflect the Court's general inability to agree on a single standard or to inject any consistency into its Establishment Clause jurisprudence. The Justices use radically different tests to decide the legal issues and disregard precedent to the extent that it conflicts with what the Court finds acceptable in the case before it.

\section{b. Regulatory Laws or Exemptions Favoring Religion}

Although regulatory laws or exemptions favoring religion confer benefits on religion, the Court has been reluctant to analyze this type of state action the same way as it does state aid to rehigion in other contexts. For example, in Larson v. Valente, ${ }^{217}$ the Court invalidated a statute inposimg registration requirements only on religious institutions that obtained inore than fifty percent of their funds from nonmembers. ${ }^{218}$ First, the Court engaged in an unprecedented equal protection analysis of the statute and concluded that the statute failed under that analysis. ${ }^{219}$ The Court then concluded that the statute's preferential nature had the effect of advancing some rehigious organizations, but not others, ${ }^{220}$ and that the statute's administration posed too great a risk of entanglement between church and state. ${ }^{221}$

214. See id. at 667.

215. Id. at 660 .

216. Although Justice Kennedy was correct in asserting that Engel v. Vitale, 370 U.S. 421, 430 (1962), meant only that direct coercion need not be shown for the Establishment Clause to be violated, the Court's opinions in School District v. Schempp, 374 U.S. 203, 223 (1963), and Committec for Public Education \& Religious Liberty v. Nyquist, 413 U.S. 756, 786 (1973), stated explicitly that coercion in general need not be shown to prove an Establishment Clause violation. Indeed, the Nyquist Court said that coercion was "irrelevant" to an Establishment Clause inquiry. Id. at 786.

217. 456 U.S. 228 (1982).

218. Id. at 231-32.

219. Id. at 247. The Larson Court cited Widmar v. Vincent, 454 U.S. 263, 269-70 (1981), aud Murdock v. Pennsylvania, 319 U.S. 105, 116-17 (1943), to support its assertion that the Establishment Clause invalidates a rule that discriminates amoug religions unless the rulc is justified by a compelling state interest and is narrowly tailored to achieve that interest. Larson, 456 U.S. at 247. The "compelliug interest" analysis in Widmar involved the Free Speech Clause rather than the Establishment Clause. In that case, the university invoked the Establishment Clause to support its argument that its asserted imterest in the separation of church and state justified the challenged abridgment of speech. See Widmar, 454 U.S. at 269-70; see also supra text accompanying notes 175 . 80. The analysis in Murdock involved both the Free Speech and Free Exercise Clauses. 319 U.S. at 108.

220. Larson, 456 U.S. at 253.

221. Id. at 255. Writing for the majority, Justice Brenuan noted that the statute was designed to target certain kinds of religious solicitors-primarily individuals who roamed public facilities trying to raise funds. Accordingly, the drafters did their best to exempt religious organizations who solicited not from individuals on the street, but rather from established private organizations willing to contribute to the religious cause. Brennan concluded that this distinction, "with [its] view 
The Court returned to a more mechanical application of Lemon's three prongs in Estate of Thornton v. Caldor, Inc., ${ }^{222}$ which involved a statute that affirmatively granted employees the right not to work on their chosen Sabbath. ${ }^{223}$ After noting the absence of a secular purpose for the statute, the Court pointed out the statute's impermissible effect of advancing retigion. ${ }^{224}$ However, it based this conclusion simply on the statute's lack of flexibility and absence of exemptions for einployers for whoin the law would cause an undue burden, ${ }^{25}$ both of which are only inarginally relevant to the degree of benefit conferred on rehgion. Like preceding Courts that based their Establishment Clause decisions on the degree of benefit conferred on religion without defining a maximum permissible degree, ${ }^{226}$ the Thornton Court did not specify how much more flexibility would render the statute valid.

Perhaps the most difficnlt situation confronting the Court in this area arose in Corporation of the Presiding Bishop of the Church of Jesus Christ of Latter-Day Saints v. Amos. ${ }^{227}$ Amos imvolved a challenge to an exeinption for religious organizations from Title VII anti-discrimination provisions. The complaining party worked for sixteen years in a gymnasium that had been owned and operated by the Mormon Church. He was discharged when it was discovered that he was no longer a Mormon in good standing. ${ }^{228}$ The Court conceded that the exemption's purpose was rehigious but noted that certain government actions for rehgious purposes are permitted under the Free Exercise Clause. 229

In assessing the effect of the exeinption, the Court characterized the exeinption not as a government action that advances rehgion, but rather as an accommodation of the church's fulfillment of its rehigious purposes. ${ }^{230}$ Accordingly, the Court analogized this situation to the provision of textbooks in Allen and the tax exemption in Walz. ${ }^{231}$ However,

towards 'religious gerrymandering," " would create impermissible entanglement. Id. at 253-55 (quoting Gillette v. United States, 401 U.S. 437, 452 (1971)).

222. 472 U.S. 703 (1985).

223. The statute at issue read: "'No person who states that a particular day of the week is observed as his Sabbath may be required by his employer to work on such day. An employee's refusal to work on his Sabbath shall not constitute grounds for his dismissal.' "Id. at 706 (quoting CONN. Gen. Stat. § 53-303e(b) (1985)).

224. Id. at 710 .

225. Id. at 709-10.

226. See, e.g., supra text accompanying notes $32,79-85$ (discussing the Court's rationales in Board of Education v. Allen, 392 U.S. 236 (1968), and Witters v. Washington Department of Services for the Blind, 474 U.S. 48 (1986)).

227. 483 U.S. 327 (1987).

228. Id. at 330 .

229. Id. at 334-35. The Court's dehineation of the point at which government action on behalf of religion becomes required under the Free Exercise Clause was, not surprisingly, incomplete. Drawing that line is a difficult task that is worthy of more discussion. That task, however, is beyond the scope of this Comment.

230. Id. at 336-37.

231. Id. 
the Court seemed to ignore the fact that the Mormon Church could not have fired the employee absent the government's decision to create an exemption to Title VII in order to allow this particular form of discrimination.

Thus, the Court has had difficulty dealing with challenges to government regulations or exemptions favoring religious groups. The Court has kept its holdings in this area as narrow as possible to avoid the force of prior cases that are at odds with its recent decisions. Where some religious groups are helped more than others, the Court strikes the government action down due to the perceived unfairness of the disparity and never reaches the broader question of whether such laws or exemptions are permissible if they aid all religions equally. Where religious individuals are granted special privileges, the Court focuses on the degree of benefit conferred on religion and the corresponding degree of burden imposed on others without reaching the broader question of whether any benefit to religion in this context is permissible. Where religious organizations discriminate in employment decisions, the Court totally avoids the Establishinent Clause implications of exemptions from anti-discrinination laws by declaring that, im this context, there is no governnient action that affirmatively advances religion. The Court simply assunies that a principled distimction exists between affirmative legislation and an exemption therefrom. Indeed, the Court's attempts to avoid furtler inconsistency $m$ this area liave resulted in decisions that liave little or no reasoning to support them; any reasoning, after all, would be irreconcilable witl some prior opimion.

\section{Conclusion: The Need for Unifying Principles}

This review of cases portrays an Estabhishment Clause jurisprudence that lacks any unifying principles. The Court's decisions do not make clear whether any aid to religion is permissible at all. To the extent that some aid may be permissible, it is not clear how nucli is constitutionally valid. Although the Court lias suggested that it is pernissible for government funds to reacli religious organizations as long as the government does not liand money directly to those organizations, it lias not explained why one approach advances religion while the otler does not.

Moreover, the role of purpose in the Court's jurisprudence is unclear. Many opinions suggest that either a religious purpose or a religious effect can invalidate state action. But the Court lias uplield state action that lias clearly religious motivations either because the action facilitates practices that are embedded in American culture or because the Court feels that the religious effect of the practice is constitutionally tolerable. To the extent that religious purpose alone can invalidate state action, the Court has been unable to decide exactly low to determine 
purpose and how much evidence of a rehigious purpose to require before deeming the purpose "religious."

Running through these decisions is a series of fundamentally different and competing ideologies. Some of the Justices apparently want absolute separation between church and state. Others are content to allow extensive interaction between the two institutions as long as no one rehigion is favored over another. No single ideology has achieved clear hegemony in the last fifty years.

A single set of principles is precisely what the Court needs to unify its treatment of the Estabhishment Clause. To some extent, it can draw these principles from the concerns expressed by the Justices in the decisions outlined above. However, the principles must also come from the political and social theory on which American democratic institutions stand and from shared notions of wliat the First Amendment should protect. The resulting theory of Establishment Clause jurisprudence should yield decisions that are logically consistent and that conform to clearly articulated values. The next Part begins the task of developing this kind of theory.

\section{III}

THEORETICAL UNDERPINNINGS OF THE RELIGION

Clauses: INDIVIDUALISM, SOCIAL CONTRACT, AND THE PRIMACY of Religious

LIBERTY

\section{A. The Dimensions of Liberal Individualism}

The path to consistency in Establishment Clause jurisprudence begins with the articulation of a theory underlying the Religion Clauses of the First Amendment. ${ }^{232}$ That theory begins with three basic features of hiberal individualism, which informs American First Amendment jurisprudence. First, and most fundamentally, hiberal individualism proceeds from the assumption that reality is accessible to all people and that its cliaracteristics are discoverable through a coinbination of einpirical observation and application of the formal, deductive rules of logic. ${ }^{233}$ Because the logic of reality parallels that of the individual, it is possible for individuals to gain knowledge about reality and then to transcend

232. The Establishment Clause and the Free Exercise Clause comprise the Religion Clauses of the First Amendment.

233. See, e.g., John Locke, AN Essay Concerning Human Understanding 646 (Peter H. Nidditch ed., 1975) ("[O]ur [f]aculties are ... enough to lead us into a full and clear discovery of our Duty, and great Concernment ...."). While Locke was certainly skeptical of humans' ability to discover truth with certainty, he seemed to believe that humans were capable of discovering, at a minimum, an objective truth, and that they could arrive at probable judgments about that truth. See id. at 646-47; see also Rogers M. SMITH, LIBERALISM AND AMERICAN CONSTITUTIONAL LAW 24-26 (1985) (discussing the role of reasoning in Locke's vision of individual liberty). 


\section{that knowledge by conceiving a more ideal reality. ${ }^{234}$}

From this fundamental epistemological premise follows the second characteristic: hberal individuahsm views people as rational and autonomous. It assumes that people are essentially rational thinkers who possess equal capacities to understand the world, to formulate their own objectives, and to develop and carry out plans to change their circumstances. ${ }^{235}$ These capacities make each person inherently deserving of equal respect ${ }^{236}$ and give equal merit to each person's conception of the good. ${ }^{237}$ Accordingly, it is morally improper to interfere with an individual's realization of any objective unless that realization interferes with others' equal opportunities to attain their objectives. ${ }^{238}$

A logical extension of individuals' inherently equal abilities to gather knowledge is the possibility of combining their abilities to increase their collective understanding and well-being. ${ }^{239}$ Herein lies the third characteristic: liberal individualism views groups as mere aggregations of individual thinkers-aggregations that are formed primarily to advance and balance the interests of the individual members. ${ }^{240}$ Further,

234. Locke "defines the end of 'practical philosophy' or 'Ethicks' [sic] as 'the Attainment of Things good and useful.'" SMITH, supra note 233, at 25 (quoting LOCKE, supra note 233, at 720). Rogers Sinith also notes that "[t]he new scientific method is concerned to acquire a knowledge of the properties of things that can allow us to inanipulate them for our purposes." Id. at 24.

235. For a general discussion of personal autonomy, see Harry G. Frankfurt, Freedom of the Will and the Concept of a Person, 68 J. PHIL. 5, 7 (1971) ("No animal other than man ... appears to have the capacity for reflective self-evaluation ...."). For a more extended discussion of this capacity for rational action, see David A.J. Richards, Toleration AND tHE Constitution 7277 (1986). For a discussion of individuals' abilities to identify their own objeetives according to their own desires or conceptions of some objective good, see JOHN RAWLS, A THEORY OF JUSTICE 127 (1971).

236. See RICHARDS, supra note 235 , at 71 . Note that this description characterizes a rightsbased conception of individualism, such as that advanced by Immanuel Kant and John Rawls. See id. at 79 ("Correspondingly, the ethical imperative, treating persons as equals, expresses for Kant a constructivist moral ideal of the principles persons would reasonably impose on thenselves as the expression of mutual respect for the like rational capacity of all to motivate themselves by practical conceptions of their ends."); see also John Rawls, Kantian Constructivism in Moral Theory, $77 \mathrm{~J}$. PHIL. 515 (1980). There are, of course, competing conceptions, such as utilitarian individualism. For a synopsis of this approach and an argument that it is an unsuitable basis on which to rest a theory of the First Amendment, see RuchaRDS, supra note 235, at 69-71.

237. Perhaps more accurately, we assuine equal merit because individuals' conceptions of the good do not lend themselves to comparison by any objective criteria.

238. See RAwLS, supra note 235 , at 60 ("[E] ach person is to have an equal right to the most extensive basic liberty compatible with a similar liberty for others.").

239. See infra text accompanying notes 263-72 (discussing the Lockean conception of society).

240. See PhILIP PeTtit, Judging Justice: AN InTRoduction to Contemporary Polmical PhILOSOPHY 45-64 (1980). This Comment deflnes society as an aggregation of individuals, not as a precxisting construct from which individuals' identities emerge. This argunnent allows for the possibility that individuals may belong to any number of groups independently of their connection to civil society. It also recognizes that those group ties, to soine extent, actually shape the qualities that liberalism identifies as unique to liuman beings-qualities like rationality and deliberation. It embraces the view, however, that civil society does not shape liumans' identity in the same way that other groups do. Accordingly, society is an aggregation of individuals whose identities are shaped in part by their uniquely human characteristics and in part by their preexisting 
groups should protect individuals' interests equally. ${ }^{241}$ Failure to do so compromises the group's legitimacy and renoves the incentive for individuals to aggregate themselves in the first place. ${ }^{242}$

This individualistic vision pervades current constitutional interpretation in general ${ }^{243}$ and First Amendment jurisprudence in particular. ${ }^{244}$ Because thought and belief are objectives in themselves and prerequisites for the attainment of many other objectives, and because merely thinking about or beheving in certain ideas alone cannot interfere with others' objectives, individualisin envisions that people should always remain free to think and believe as they choose. ${ }^{245}$ Indeed, under the liberal conception, freedoin of thought is necessary for "intellectual progress." 246 This progress is botls an end in itself and, more importantly, a means to greater personal freedoin, because enhanced knowledge and powers of thouglit facilitate the attainment of individual objectives. ${ }^{247}$ The Religion Clauses of the First Amendment reflect this concern for freedoin of thought. ${ }^{248}$

The intellectual freedoin envisioned by liberal theory extends beyond mere thouglit and belief, lrowever. It reaclies into the realm of discourse between rational thinkers. ${ }^{249}$ Accordingly, the Free Speech Clause of the First Amendment guarantees individuals' freedom to express their thoughts verbally. Througlı free discourse, liberal individualism posits, individuals will achieve two goals: faster and more certain discovery of trutl1 ${ }^{250}$ and development of each individual's powers of reason. ${ }^{251}$ These goals, in turn, help the individual and the group realize

cultural, religious, and racial associations. This conception of the state and society informs the remaining discussion in this Comment.

241. Our society is committed to tle principle tlat, as long as they do not violate the rights of others, individuals may pursue their own conceptions of the good. We are also committed to the idea that the legal order should remain neutral among these conceptions, not favoring some or disfavoring others on the grounds of their intrinsic merit.

Anthouy T. Kronman, Paternalism and the Law of Contracts, 92 YALE L.J. 763, 794-95 (1983).

242. See Michel Rosenfeld, Contract and Justice: The Relation Between Classical Contract Law and Social Contract Theory, 70 IowA L. Rev. 769, 779 (1983) ("Individualism is thus bound to reject as illegitimate any social orgarization that seeks to impose a particular vision of the good above all others.").

243. SMITH, supra note 233 , at 35 .

244. Id. at 92-99.

245. Id. at 92 (uoting Locke's "fundamental concern for freedom of spiritual and intelleetual conscience").

246. Id.

247. Id. at 101.

248. Id. at 94 ("[T]he American founders gave freedom of religious conscience pride of place among rights and argued that it aided the triumph of truth and social stability.").

249. Id.

250. This is the famous "marketplace of ideas" concept, which posits that where ideas compete in a sphere of discourse outside any particular individual, those with the greatest intrinsic merit will triumph. See id. at 100 .

251. Id. at 96. 
their chosen objectives. ${ }^{252}$

\section{B. Individualism in the Social Context: Social Contract Theory}

From this mdividualist conception stems a particular view of the proper purpose and form of civil society. Although individuals possess their intrinsic rationality and autonomy prior to the formation of society and are subject, in theory, to all of hiberal individualism's principles and prescriptions, Lockean theory concedes that not every person is naturally mclined to obey individualism's prohibition against interfering with others' objectives. ${ }^{253}$ Accordingly, individuals who pursue their chosen objectives are vulnerable to others' interference.

The Lockean "state of nature" metaphor, in which people can be killed or have their possessions taken forcibly by those who are stronger, depicts the insecurity that people would feel absent soine institution to enforce hiberal individualism's moral requirements. ${ }^{254}$ To avoid this insecurity, people form a society to preserve their inutual security from this interference. $^{255}$ They create an institution-the state-to enforce the tenets of individualisin. ${ }^{256}$ The state is designed to be stronger than any aggregation of individuals within the society but is supposed to act only in the interests of all individuals.

Because the interests of one individual may not always coincide with the interests of others, society must find a way to choose among conflicting interests without violating individuahist principles. Accordingly, Lockean theory allows society's members to choose a majoritarian form of government, which carries the potential to override or to ignore individual interests im specific cases. ${ }^{257}$ But the inajority's will alone does not justify the infringement of fundamental individual rights. ${ }^{258}$

Although Lockean society is constructed primarily to safeguard

252. See id. at 97. Societal goals in particular, according to John Stuart Mill, include competent citizenry and preventing excessive centralization of power. See id. These goals fit logically into the individualist framework. A population composed of people whose powers of reason are well developed can effectively inquire into government activities and, in so doing, hold the government accountable for its actions. Further, to the extent that some objective truth exists, the knowledge of this truth allows people to make informed choices among potential leaders and various public policies.

253. See Jofn Locke, Second Treatise of Government 6-7 (Thomas P. Peardon ed., 1952).

254. Id. at 13-14.

255. Id. at 54 (arguing that society is formed by individuals who agree "with other men to join and unite into a community, for their comfortable, safe, and peaceable living one amongst another, in a secure enjoyment of their properties and a greater security against any that are not of it"). Note that one need not embrace Locke's state-of-nature metaphor in order to embrace his conception of the proper purpose and form of society.

256. Id. at $70-73$.

257. Id. at 73-74.

258. Id. at 79. Note that the term "property" appears to encompass an mdividual's life, liberty, and estate. Id. at 48, 79; see also Jeffrey S. Kochlinger, Substantive Due Process Analysis and the Lockean Liberal Tradition: Rethinking the Modern Privacy Cases, 65 IND. L.J. 723, 730 (1990) 
individual interests, individuals' rights are not absolute. They can be infringed by an individual's express consent, or to ensure that all members of society enjoy a similar degree of hiberty. ${ }^{259}$ Locke posited that since individuals understand that some societal enforcement mechanism is necessary to protect each person's physical security, they agree to surrender soine of their fundaniental rights in order to allow equal distribution of those rights. ${ }^{260}$ Remaining within a society, therefore, constitutes an individual's tacit agreement to be bound by that society's individuahistic prescriptions and to be subject to the state's enforcement power. ${ }^{261}$ It follows that one becomes a member of society only by consent. ${ }^{262}$ This vision of imdividuals agreemg to surrender some hiberty in exchange for society's collective agreement to protect certain core freedoms is at the heart of the contractarian vision for society.

What are the core freedoms, according to Locke, that society protects? At the very least, they mclude life, liberty, and property. ${ }^{263}$ While it is possible to define the terms "life" and "property" in a relatively concrete manner, the meaning of "liberty" is less clear. At a minimum, though, "hberty" must include the freedom of thought and expression that individuahsm demands. ${ }^{264}$

To ensure that these individual freedoms are protected, Lockean society distinguishes the public and the private spheres. ${ }^{265}$ The boundaries of the private sphere correspond to the extent to which the govern-

(noting that, in Lockean society, "the majority . . . would never take action arbitrarily or unnecessarily to limit these [individual] rights").

259. LOCKE, supra note 253, at 79; see also RAwLS, supra note 235, at 60 (1971) (arguing that "each person is to have an equal right to the most extensive basic hberty compatible with a similar liberty for others"). Since the preservation of the state's enforcement power is necessary for the preservation of the society, infringement of fundamental rights is also allowed where necessary for the survival of the state.

260. LOCKE, supra note 253 , at $48-49$.

261. Id. at $68-70$.

262. Id. at 54; see also SMITH, supra note 233, at 44 (noting that the formation of a Lockean government requires first that "everyone ... consent to membership in a political society"). Since membership in a society entails the surrender of fundamental liberties, forcing an individual to become a member of a society amounts to forcing that person to give up fundamental rights without sufficient justification. Although Locke posits that it is rational to join civil society, he dernies that one is morally required to do so. LocKE, supra note 253 , at 66-68.

263. Locke, supra note 253 , at 48 . For Locke,

liberty is essential to human happiness as both an end and a means. It is essential in itself, because without it we feel so uneasy that life becomes miserable, and it is a means, since with it we progress toward all our goods. It is also a defining characteristic of our humanity, an exercise of the capacity that sets us above animals, and the part of our human nature that enables us to act in accordance with the determinations of our reason.

SMITH, supra note 233, at 29. Society may also be expected to protect a degree of "happiness" for its members. Koehlinger, supra note 258, at 732. Although this term is even more ambiguous than "liberty," the Lockean inodel secms to contemplate that one should be free to pursue one's preferences to the extent that the pursuit does not interfere with others' rcalization of their preferences.

264. See supra text accompanying notes $245-52$.

265. See LOCKE, supra note 253 , at 47 (distinguishing "[t]he society betwixt parents and 
ment must uphold these fundamental rights. This sphere consists of "freely-willed interpersonal interactions," 266 which necessarily encompass thought, belief, and a degree of verbal expression. The private sphere also includes consensual economic and social interactions between individuals. ${ }^{267}$

The public splere, in contrast, is "designed to preserve and protect sucl interactions."268 The government is autliorized to act in the public sphere in at least two ways. First, it inay protect private interactions from interference by third parties. ${ }^{269}$ Second, it may curtail such interactions if they harm people who have not freely chosen to participate in the interactions. ${ }^{270}$ It is only in the private sphere-not the public spherethat the government is completely forbidden to interfere with fundamental rights.

This conception of the nature and extent of individual liberty is a negative one. It emphasizes the individual's isolation in the private sphere from potentially intrusive acts of other individuals. More inportantly, it highlights how limited the state's authority to infringe on these riglits really is.

This Lockean vision contrasts sharply with a positive conception of freedoin, which empliasizes affirmative riglits not only to formal equality, but also to economic and social equality. ${ }^{271}$ Under the Lockean conception, there is no mention of any affirmative entitleinents to tangible resources such as lousing, food, or medical care from the government. Altlough the government is not precluded from giving this kind of assistance, its mandate is simply to protect individuals' exercise of fundamental riglits such as preserving life, acquiring resources, freely associating with other individuals, and developing their faculties as they would in an ideal state of nature where everyone adhered to individualisin's prescriptions and restrictions. Government's prinary task, therefore, is to protect people from harming each other pliysically or economically. ${ }^{272}$

All of the elements described liere comprise the contractarian model of society. Like individualism, this model underlies the U.S.

children" from the "politic society"). For a more extensive discussion of this distinction, see Morton J. Horwitz, The History of the Public/Private Distinction, 130 U. PA. L. REV. 1423 (1982).

266. Nancy S. Ehrenreich, Pluralist Myths and Powerless Men: The Ideology of Reasonableness in Sexual Harassment Law, 99 YALE L.J. 1177, 1180 (1990).

267. See Horwitz, supra note 265, at 1424 (noting that according to 19th-century liberal thought, the laws of torts, of contracts, of property, and of commercial transactions govern conduct in the private sphere).

268. Ehrenreich, supra note 266, at 1181.

269. See id. at 1180-81.

270. See id. at 1181.

271. For a discussion of the distinction between positive and negative rights, see Michel Rosenfeld, Between Rights and Consequences: A Philosophical Inquiry into the Foundations of Legal Ethics in the Changing World of Securitics Regulation, 49 GEO. WASH. L. REV. 462, 481-83 (1981).

272. See Ehrenreich, supra note 266, at 1181. 
Constitution. In fact, Locke's ideas pervade the text of the Constitution itself. ${ }^{273}$ Less obvious, but equally significant, is his influence on the drafters of the Bill of Rights. They viewed most of the rights mentioned in that document as fundamental. ${ }^{274}$

\section{Freedom of Conscience as a Fundamental Individual Liberty Under Contractarian Theory}

This contractarian expression of individualism posits that one of the essential rights that society must protect in order to rennain legitimate is freedom of conscience. ${ }^{275}$ For example, Locke said exphicitly that the state's violation of basic human rights, such as the right to conscience, justifies disobedience or rebellion. ${ }^{276}$ Although Locke adınitted that one's ideas or beliefs may be erroneous, ${ }^{277}$ he demed that such error justifies government interference with an individual's choices, because such interference would constitute an unwarranted assumption by the government of infallibility. ${ }^{278}$

Significantly, Locke supported freedom of conscience only for those who are tolerant of others' behefs and, more importantly, only for those who behieve in God. ${ }^{279}$ However, as Professor David Richards notes, both of these restrictions can be rejected without discarding Locke's broader mandate for the protection of conscience. ${ }^{280}$ First, if Locke equated intolerance with lack of respect, then freedoin of conscience inust be allowed for the "intolerant" as well as the tolerant. If humans are viewed as equal because of their capacities for rational thought, respect for rationality deinands that society allow different substantive beliefs-even prejudices-einbraced by different, but presumably equally rational, minds. Of course, if Locke equated intolerance of others' behiefs with interference with those betiefs, then his conception of society does

273. The Due Process Clause of the Fifth Amendment, for example, prohibits the government from depriving individuals of "hife, hiberty, or property" without due process of law. U.S. CoNST. amend. V; see also Koehlinger, supra note 258, at 733 (noting that "Locke's influence is pervasive in the Constitution").

274. Koehlinger, supra note 258, at 731-32. "These rights are not, in other words, fundamental because they find mention in the written instrument; they find mention there because fundamental." Edward S. Corwin, The Basic Doctrine of American Constitutional Law, 12 MiCH. L. REv. 247, 24748 (1914).

275. See supra text accompanying notes 245-47. Professor David Richards argues that "the central case, both historically and philosophically, to be made on behalf of human rights is the argument for conscience, and many other claims of rights may be regarded as generalizations or elaborations of this focal argument." RICHARDS, supra note 235, at 85 . This argument is consistent with Locke's emphasis on humans' inherent capacity for rational thought and the need to protect their freedom to exercise that rationality. SMITH, supra note 233, at 29.

276. RICHARDS, supra note 235 , at 91 .

277. See id. This admission is consistent with Locke's belief in the existence of an objective, discoverable truth.

278. See id. at 91-92.

279. Id. at 95 (citing JoHN LOCKE, 6 Works of JoHN LOCKE, $45-47$ (1824)).

280. Id. 
require society to intervene to stop that interference. ${ }^{281}$ Absent such an act, however, society must protect all individuals' rights of conscience by allowing disrespect for opposing views.

Second, it is possible to extend protection under Locke's analysis to atheists. As Professor Richards argues, Locke's exclusion of atheists froin protection probably steins from his theory of why individuals' consciences inerit protection in the first place: individuals inust be allowed to make inoral decisions on the basis of what they, and they alone, perceive to be God's deinands on thein. ${ }^{282}$ Upon conceding that there are non-theistic ethical guides, ${ }^{283}$ it is a logically simple inatter to protect the freedoin of conscience of atheists and people of all beliefs. The argument presented in this Comment, therefore, assumes that atheistic religious behiefs should enjoy the same protections and incur the same burdens under the Religion Clauses as do traditional religious behefs.

\section{First Amendment Protection of Freedom of Conscience: Religious Liberty as the Core Value Underlying the Establishment Clause and the Primary Guide to Establishment Clause Interpretation}

Given the importance of freedom of conscience under the contractarian model, this Section develops the significance of freedom of conscience under the Establishment Clause. First, it hightights how important freedom of conscience was to the drafters of the First Amendment. Second, it establishes that individual religious liberty is in fact the primary value underlying the Religion Clauses. Finally, it concludes that this basic substantive value-rather than original intentshould be the primary guide to Establishment Clause interpretation.

\section{Consistent Concern for Individual Religious Liberty in the Drafting}

of the First Amendment and in the Supreme Court's

Establishment Clause Jurisprudence

Although Locke's social contract metaphor has been criticized, ${ }^{284}$ a strong argument can be made that his conceptions of individualisin and of the goals of society lie at the heart of the First Amendment's Religion Clauses. Locke's notion of freedoin of conscience reemerges both in the writings of those who inspired and drafted the First Ainendment and in the opinions of the Supreme Court Justices who have interpreted the

281. See id.

282. Id. at $96-97$.

283. Much has been written on the subject of non-theistic ethical guides. See, e.g., ANTHONY A. COOPER, AN INQUiRy CONCERNING VIRTUE, OR MERIT 15-22 (1977); FRANCIS Hutcheson, An Inquiry Concerning the Original of Our Ideas of Virtue or Moral Good, in AN INQUIRY INTO THE ORIGINAL OF OUR IDEAS OF BEAUTY AND ViRTUE 121, 162-95 (1726).

284. For a concise, informative discussion of some of these criticisms, see SMrTH, supra note 233 , at $36-59$. 
Religion Clauses. These writings einphasize repeatedly the essential value of religious liberty. ${ }^{285}$

References to freedom of conscience in general and religious liberty in particular appeared most prominently in James Madison's Memorial and Remonstrance Against Religious Assessments. ${ }^{286}$ Because his language so closely parallels that of Locke, ${ }^{287}$ it is wortl quoting liere:

The Religion then of every man must be left to the conviction and conscience of every inan; and it is the right of every man to exercise it as these nnay dictate. This right is in its nature an unalienable riglit. It is unalienable; because the opinions of men, depending only on the evidence conteinplated by their own minds, cannot follow the dictates of other men: It is unalienable also; because what is here a riglit towards inen, is a duty towards the Creator. ${ }^{288}$

Madison's statement is especially significant because the Supreme Court has frequently cited it to highlight the underlying theory of the Establishment Clause. ${ }^{289}$

Thoinas Jefferson's articulation of the famous "wall of separation" metaphor was also based primarily, if not exclusively, on the same notion of freedoin of conscience:

Believing with you that religion is a matter which lies solely between man and his God, that he owes account to none other for his faith or his worship, that the legislative powers of government reach actions only, and not opinions, I contemplate with sovereigu reverence that act of the whole American people which

285. For purposes of this discussion, I define religious liberty as freedom from government interference with mdividual choice to believe or disbelieve religious ideas and to participate or not participate in religious activities.

286. James Madison, Memorial and Remonstrance Against Religious Assessments (1785), reprinted in The Complete Madison 299-306 (Saul K. Padover ed., 1953).

287. See RICHARDS, supra note 235, at 113. Professor David Ricliards notes that Madison's words contain the same notion of equal respect for rational individuals that Locke empliasizes. Id. at 113.

Other statements by Madison, thougl less famous, express substantially the same idea. For example, at a Virginia Convention that met in Williamsbnrg on May 6, 1776, to draft a declaration of independence froin Great Britain, Madison proposed a version that read:

That religion, or the dnty which we owe to our CREATOR, and the manner of discharging

it, can be directed only by reason and conviction, not by force or violence; and therefore, that all men are equally entitled to enjoy the free exercise of religion, according to the dictates of conscience, unpunished and unrestrained by the magistrate, Unless the preservation of equal liberty and the existence of the State are manifestly endangered ....

Daniel L. Dreisbach, Real Threat and Mere Shadow 138 (1987) (quoting 1 The Papers OF JAMES MADISON (William M.E. Rachal et al. eds., 1962)).

288. MADison, supra note 286, at 299-300. Madison further remarked: "Whilst we assert for ourselves a freedom to embrace, to profess and to observe the Religion which we believe to be of divine origin, we cannot deny an equal freedom to tliose whose minds have not yielded to the evidence which las convinced us." Id. at 301.

289. See, e.g., Wallace v. Jaffree, 472 U.S. 38,53 n.38 (1985); Walz v. Tax Comm'n, 397 U.S. 664, 719-20 (1970) (Douglas, J., dissenting); Everson v. Board of Educ., 330 U.S. 1, 64 (1947). 
declared that their legislature should "Inake no law respecting an establishment of religion, or prohibiting the free exercise thereof," thus building a wall of separation between Church and State. ${ }^{290}$

The Supreine Court's Establishment Clause decisions, though far from consistent, share a common theme: concern for rehious liberty. For example, in support of its holding in Everson v. Board of Education, ${ }^{291}$ the Court einphasized that according to Madison, the "best interest of a society required that the minds of inen always be wholly free."292 This characterization echoes Madison's words in Memorial and Remonstrance Against Religious Assessments. ${ }^{293}$ Similarly, in Wallace v. Jaffree, ${ }^{294}$ Justice Stevens renarked that "freedom of conscience [is] the central liberty that unifies the various Clauses in the First Amendinent."295 $\mathrm{He}$ cited an earlier case, Cantwell v. Connecticut, ${ }^{296}$ to support his claim:

The constitutional inhibition of legislation on the subject of rehigion has a double aspect. On the one hand, it forestalls coinpulsion by law of the acceptance of any creed or the practice of any form of worship. Freedom of conscience and freedom to adhere to such rehigious organization or form of worship as the individual may choose cannot be restricted by law. On the other hand, it safeguards the free exercise of the chosen form of rehigion. ${ }^{297}$

Even when Justices disagreed about holdings or particular applications of legal tests, they often expressed their overriding concern with freedom of conscience. In School District v. Schempp, ${ }^{298}$ Justice Brennan reflected the Court's consistent concern for individual religious liberty: " 'Man's relation to his God was made no concern of the state. He was granted the right to worship as he pleased and to answer to no man for the verity of his rehigious views." "299 In the same case, Justice Goldberg noted that the "smgle end" of the Rehion Clauses is "to proinote and assure the fullest possible scope of rehigious hberty and tolerance for all

290. DREISBACH, supra note 287 , at 125 (emphasis added) (quoting Letter from Thomas Jefferson to Nehemiah Dodge, Ephraim Robbins, and Stephen S. Nelson, A Committee of the Danbury Baptist Association, in the State of Connecticut (Jan. 1, 1802), in THE L1FE AND Selected Writings of Thomas Jefferson 332 (Adrienne Kock \& William Peden eds., 1944)).

291. 330 U.S. 1 (1947).

292. Id. at 12.

293. See supra text accompanying note 288 .

294. 472 U.S. 38 (1985).

295. Id. at 50.

296. 310 U.S. 296 (1940).

297. Jaffree, 472 U.S. at 50 (quoting Cantwell, 310 U.S. at 303); see also McGowan v. Maryland, 366 U.S. 420, 440 (1961) (quoting one of Madison's proposed versions of the First Amendment-a version that emphasized freedom of conscience).

298. 374 U.S. 203 (1963).

299. Id. at 244 (Brennan, J., concurring) (quoting United States v. Ballard, 322 U.S. 78, 87 (1944)). 
and to nurture the conditions which secure the best hope of attainment of that end."300 Similarly, in Marsh v. Chambers ${ }^{301}$ Justice Brennan noted two closely related purposes of the First Amendment: protecting the "individual right to conscience" and preventing state interference in the "essential autonoiny of rehgious life."302

\section{Primacy of Religious Liberty over Other Possible Values Underlying the Establishment Clause}

Although it has been suggested that values otlier than religious liberty are central to the Rehigion Clauses, a close analysis suggests that any such values are, at most, secondary. ${ }^{303}$ Thus, when two different values conflict, rehigious hiberty should take precedence.

One suggested alternative value is "strict separation" between church and state. Professor Leo Pfeffer contends that "separation guarantees freedoin and freedom requires separation. The draftsmen of the [First A]mendment regarded freedoin of religion and establishment as incompatible. American constitutional history and tradition do not justify an apportionment of values between disestablishment and freedoin."304 However, Pfeffer's own words reveal-though he inay fail to recognize-that separation is merely a policy designed to protect the underlying value: freedoin.

Further, it cannot plausibly be clanned that strict separation is sufficient or necessary to guarantee religious liberty. It is not sufficient because, as Arlin Adams and Cliarles Emmerich point out, the twentieth-century governments that have distanced theinselves most froin traditional religion lave allowed the least freedom for their citizens. ${ }^{305}$

300. Id. at 305 (Goldberg, J., concurring).

301. 463 U.S. 783 (1983).

302. Id. at 803 (Brennan, J., dissenting).

303. Many commentators have argued persuasively that religious liberty is the core animating value of the Religion Clauses. See, e.g., Arlin M. Adams \& Charles J. Emmerich, A Heritage of Religious Liberty, 137 U. PA. L. REv. 1559, 1595-645 (1989) (discussing possible values underlying the Religion Clauses and concluding that religious liberty is paramount); Jesse H. Choper, Religion in the Public Schools: A Proposed Constitutional Standard, 47 MinN. L. REV. 329, 333 \& nn.19-20 (1963) (arguing that a coercion-based Establishment Clause standard best protects the primary value underlying the Clause-religious hiberty); Wilber G. Katz, The Case for Religious Liberty, in RELIGION IN AMERICA 95, 97 (John Cogley ed., 1958) (trying to give content to the phrase "separation of church and state" and arguing that such content must be given with reference to the core value of rehigious hiberty); Wilber G. Katz, Freedom of Religion and State Neutrality, 20 U. CHI. L. REv. 426, 428 (1953) (arguing that neutrality may not always protect the core value of the Religion Clauses-religious hiberty).

304. Leo Pfeffer, Freedom and/or Separation: The Constitutional Dilemma of the First Amendment, 64 MiNN. L. REV. 561, 564 (1980) (footnote omitted).

305. Adams \& Emmerich, supra note 303 , at 1599 n.173. Of course, it might be argued that such governments failed to honor the disestablishment principle because they actually "established" atheism, or at least anti-religion. However, the strict separation principle as articulated by Professor Pfeffer does not describe the point at which separation between church and state constitutes establishment of anti-religion. He may believe either that only the establishment of a theistic religion 
In addition, an argument that strict separation is still necessary for religious freedom assumes that the government can avoid benefitting or favoring a belief system when it acts. ${ }^{306}$ Favoring beliefs not rooted in religion seems, under the conscience-centered conception of religion and religious liberty advanced in this Comment, ${ }^{307}$ logically indistinguishable from favoring behefs rooted in religion. ${ }^{308}$ The Court has been unable to articulate principled boundaries for the strict separation principle to prevent the kind of "hostility" that "would be at war with our national tradition as embodied in the First Amendment's guaranty of the free exercise of rehigion."309

Another value that some consider central to the Establishment Clause is the preservation of states' riglits. Commentators have relied on this value to argue that the First Amendment forbids the establishment of a church only by the national government. ${ }^{310}$ However, as Professor Jesse Clioper points out, the Supreme Court has unambiguously rejected this argument. ${ }^{311}$ In view of the individualistic underpinnings of the First Amendinent, this rejection seems proper. Otherwise, state governments could violate citizens' rights to individual freedom of conscience and the First Amendment would lose much of its power to perforin its primary function.

A third possible primary value underlying the Establishment Clause is the prevention of government entanglement with religion-a value expressed in the third prong of the Lemon test. ${ }^{312}$ The anti-entangleinent

is objectionable or that the kind of hostility toward religion observed in these societies does not amount to an establishment of nonreligion.

306. For a discussion of the inherent problems with government neutrality toward religion, see infra text accompanying notes 333-54.

307. See supra Sections III.C-D.1.

308. The Supreme Court agrees. In Epperson v. Arkansas, 393 U.S. 97 (1968), the Court declared:

Government in our democracy, state and national, must be neutral in matters of religious theory, doctrine, and practice. It may not be hostile to any religion or to the advocacy of no-religion; and it may not aid, foster, or promote one religion or religious theory against another or even against the militant opposite. The First Amendment mandates government neutrality between religion and religion, and between religion and nonreligion.

Id. at 103-04. The possible existence of a third category that is neither religious nor nonreligious is addressed and dismissed infra text accompanying notes 343-47.

309. McCollum v. Board of Educ., 333 U.S. 203, 211-12 (1948).

310. See, e.g., DREISBACH, supra note 287 , at 89-96.

311. Choper, supra note 303, at 331 \& n.7; see, e.g., Engel v. Vitale, 370 U.S. 421, 430 (1962) (The Establishment Clause applies to "government in this country, be it state or federal"); Torcaso v. Watkins, 367 U.S. 488, 495 (1961) ("neither a State nor the Federal Government" may violate the Establishment Clause); Zorach v. Clauson, 343 U.S. 306, 309 (1952) ("[T]he First Amendment . . . prohibits the states from establishing religion or prohibiting its free exercise."); Everson v. Board of Educ., 330 U.S. 1, 15 (1947) ("Neither a state nor the federal government can set up a church."); Cantwell v. Connecticut, 310 U.S. 296, 303 (1940) ("The Fourteenth Amendment has rendered the legislatures of the states as incompetent as Congress to enact [laws that violate the Religion Clauses].").

312. See Lemon v. Kurtzman, 403 U.S. 602, 613 (1971); supra text accompanying note 36. 
value has two subsets. The first subset is avoiding administrative entanglement. The second subset is preventing pohtical division along religious lines.

Unfortunately, the Court has never made clear why administrative entanglement is inherently unacceptable. The closest it has come is its statement in McCollum v. Board of Education ${ }^{313}$ that "religion and government can best work to achieve their lofty aims if each is left free from the other within its respective spliere."314 But as Professor Choper notes, no real dangers arise from administrative imteraction between religious and governmental authorities. ${ }^{315}$ First, there is no evidence that the religious and governmental interests will tend to merge merely because churches and governments work together. ${ }^{316}$ If such a threat actually existed, any successful government regulation of rehgious institutions might be unconstitutional because the government and the institution might be found to be "working together" siniply to make the regulatory scheme successful. ${ }^{317}$ Second, there is no evidence that extensive administrative collaboration between governmental and religious authorities has ever substantially threatened the free exercise of religion. ${ }^{318}$ Despite this lack of evidence, members of the Supreme Court have repeatedly condemned close administrative interaction between cliurcli and state. ${ }^{319}$

The second subset-preventing political division along religious lines-is also commonly invoked by the Court when it discusses entanglement. ${ }^{320}$ In Committee for Public Education \& Religious Liberty $v$.

313. 333 U.S. 203 (1948).

314. Id. at 212. In Aguilar v. Felton, 473 U.S. 402 (1985), the Court specified what it feared would be the consequence of entanglement: limitations on the freedom of adherents and nonadherents. It did not, however, specify exactly how entanglement necessarily reduces freedom. At any rate, the Court's fear of administrative entanglement appears to rest ultimately on a concern about religious liberty.

315. Jesse H. Choper, The Religion Clauses of the First Amendment: Reconciling the Conflict, 41 U. PrTT. L. REV. 673, 681-83 (1980).

316. Id. at 682 .

317. Id.

318. Id.

319. See, e.g., Texas Monthly, Inc. v. Bullock, 489 U.S. 1, 20 (1989) (plurality opinion) ("Not only does the exenption seem a blatant endorsement of religion, but it appears, on its face, to produce greater state entanglement with religion tlian the denial of an exemption."); Bowen v. Kendrick, 487 U.S. 589, 649 (1988) (Blackmun, J., dissenting) ("[T]he unconstitutionality of the statute beconies even more apparent when we consider the unprecedented degree of entanglement between Church and State required to prevent subsidizing the advancement of religion . . . ."); Aguilar v. Felton, 473 U.S. 402, 409 (1985) ("[T]lie supervisory system established . . . inevitably results in the excessive entanglement of cliurch and state, an Establishment Clause concern distinct from that addressed by the effects doctrine."); Lemon v. Kurtzman, 403 U.S. 602, 620 (1971) ("This kind of state inspection and evaluation of the religious content of a religious organization is frauglit witl the sort of entanglenıent that the Constitution forbids."); Walz v. Tax Conım'n, 397 U.S. 664, 668 (1970) (" $[F]$ or the men who wrote the Rehigion Clauses of the First Amendnient the 'establishment' of a religion connoted sponsorship, financial support, and active involvement of tle sovereign in religious activity.").

320. See, e.g., Lynch v. Donnelly, 465 U.S. 668, 689 (1984) (O'Connor, J., concurring) 
Nyquist, ${ }^{321}$ the Court based its decision in part on its belief that "competition among religious sects for pohtical and religious supremacy has occasioned considerable civil strife."

In higlt of the history of the Religion Clauses, this concern is puzzling. As Professor Daniel Dreisbach notes, ${ }^{323}$ and as the Court admitted in Larson v. Valente, ${ }^{324}$ Madison actually envisioned competition between religious sects. Only through this competition, Madison beheved, could rehigious pluralism and, in turn, individual religious liberty, be preserved..$^{325}$

Certainly, Madison did oppose the kind of political divisiveness engendered by the government's alignment with a particular sect. He felt that the strife caused by sects coinpeting for the privilege of that alliance would constitute the kind of liarmful "faction" that lie wrote about in The Federalist No. $10 .{ }^{326}$ But it does not follow that just because divisiveness results from establishment of rehigion, the risk of divisiveness necessarily indicates an establishment. ${ }^{327}$ Justice O'Connor must be cor-

("Pohtical divisiveness is admittedly an evil addressed by the Establishment Clause."); Marsh v. Chambers, 463 U.S. 783, 805 (1983) (Brennan, J., dissenting) ("Finally, the principles of separation and neutrality help assure that essentially religious issues, precisely because of their importance and sensitivity, not become the occasion for battle in the political arena."); Larson v. Valente, 456 U.S. 228, 253 (1982) (noting that the tax programs at issue carried a risk of fragmontation along religious lines); Committee for Pub. Educ. \& Religious Liberty v. Nyquist, 413 U.S. 756, 796 (1973); Lemon, 403 U.S. at 622 ("Ordinarily political debate and division, however vigorous or even partisan, are normal and lealtly manifestations of our deinocratic system of government, but political division along religious lines was one of the principal evils agamst which the First Amendunent was intended to protect."); Walz, 397 U.S. at 695 (Harlan, J., concurring) ("[G]overnment involvennent, while neutral, unay be so direct or in such degree as to engender a risk of politicizing religion."); School Dist, v. Scliempp, 374 U.S. 203, 307 (1963) (Goldberg, J., concurring) (Government activity may be "so significantly and direetly in the rcalm of the sectarian as to give rise to ... divisive influences and inhibitions of freedom."); Engel v. Vitale, 370 U.S. 421, 429 (1962) (noting the "anguisl, liardship and bitter strife that $c[a n]$ come when zealous religious groups struggle[ ] with one another to obtain the Government's stamp of approval.").

321. 413 U.S. 756 (1973).

322. Id. at 796.

323. See DREISBaCH, supra note 287 , at 147.

324. See 456 U.S. at 245.

325. James Madison, Statement in Virginia Convention (June 12, 1788), reprinted in THE COMPLETE MAdison, supra note 286, at 306. Note that Thomas Jefferson lad a similar view of religious coinpetition:

[A]nd finally, that trutl is great and will prevail if left to herself; that she is the proper and sufficient antagonist to error, and has nothing to fear from the confict unless by luman interposition disarmed of her natural weapons, free argument and debate; errors ceasing to be dangerous when it is permitted freely to contradict them.

ThOMAS JEFFERSON, A BILI FOR ESTABLISHING RELIGIOUS FREEDOM (1777), reprinted in 2 ThE Papers of Thomas JefFerson 546 (Julian P. Boyd ed., 1950) (emphasis added). For an overview of Jefferson's position, see WILLIAM R. EsTEP, REVOLUTION WITHIN THE REVOLUTION 150-55 (1990).

326. See DREISBACH, supra note 287 , at 147.

327. As Professor Choper notes, if divisiveness indicated establislunent, then the mere fact that religious groups strongly supported or opposed certain legislation miglit automatically invalidate that legislation. Choper, supra note 315 , at 684 . 
rect, then, when she posits that divisive potential is, at most, evidence of a governmental endorsement of rehigion. ${ }^{328}$

Even the use of divisiveness as evidence of impermissible endorsement is problematic because it rests on three questionable assumptions. The first assumption is that the Court has the constitutional authority to intervene to reduce rehigiously motivated political conflict. ${ }^{329}$ The second is that conflicts involving rehgious views should be prevented because they are more damaging than those involving purely secular views. ${ }^{330}$ The third is that it is possible to alleviate these kinds of divisions by judicial decision. ${ }^{331}$

The final value to be considered is neutrality. However, since neutrahty seems to be rooted in a deeper concern that the government treat all belief systems equally, neutrality-like strict separation-is merely a pohicy designed to further a deeper value. Because some commentators argue that this equality is one of the core values underlying the Rehion Clauses, ${ }^{332}$ the pohicy of neutrality deserves a inore extended discussion here.

One way, in theory, to carry out this pohicy and further the deeper value is to keep the state totally uninvolved with religion and nonreligion $^{333}$ or to make sure that the state's involvement benefits all behief systems-rehigious and nonrehious-equally. ${ }^{334}$ Although historical writings support the proposition that government should not discriminate among rehigious sects, ${ }^{335}$ they do not clearly support the idea that

328. Lynch v. Donnelly, 465 U.S. 668,689 (1984) (O'Connor, J., concurring).

329. See Choper, supra note 315 , at 684 .

330. See Phillip E. Johnson, Concepts and Compromise in First Amendment Religious Doctrine, 72 CALIF. L. REv. 817, 830 (1984) (questioning whether, in modern American society, issues surrounding school prayer or public religious displays are inore likely to cause intense conflicts than are secular issues).

331. Professor Johnson notes that decisions like Roe v. Wade, 410 U.S. 113 (1973) (establishing a linrited constitutional right to abortion), have increased, not decreased, political divisions. Johnson, supra note 330, at 830. Further, refusing to grant aid to parochial schools is just as likely to engender political conflict as is granting such aid. See Choper, supra note 315, at 684. For a nore extended criticism of the political divisiveness component of the entanglement inquiry, see Edward M. Gaffney, Jr., Political Divisiveness Along Religious Lines: The Entanglement of the Court in Sloppy History and Bad Public Policy, 24 ST. Louts U. L.J. 205 (1980).

332. See Philip B. Kurland, Of Church and State and the Supreme Court, 29 U. CHr. L. Rev. 1, 6 (1961) (arguing that no classification based on religion is permissible).

333. See Michael D. Lieder, Religious Pluralism and Education in Historical Perspective: $A$ Critique of the Supreme Court's Establishment Clause Jurisprudence, 22 WAKE FOREST L. REV. 813, 867-73 (1987) (classifying strict separation as a subset of the broader concept of neutrality). I address strict separation separately because commentators like Professor Leo Pfeffer have inade the remarkable claim that strict separation is an independent value that the Establishment Clause seeks to protect rather than an approach designed to fulfill the goal of neutrality. Pfeffer, supra note 304, at $564-70$.

334. See Lieder, supra note 333, at 873 (introducing what the author considers to be the second subset of neutrality: equal treatment of religion and nonreligion).

335. See, e.g., MADISON, supra note 286, at 299-306. Madison states:

Above all are they to be considered as retaining an "equal title to the free exercise of 
the state may not discriminate between religion and nonreligion. ${ }^{336} \mathrm{Nev}$ ertheless, the Court has often stressed that state action must be neutral between what it labels "rehgion" and "nonreligion."337 The Court seems correct in recognizing that historical records manifesting the intentions of the framers should not bind the courts to the extent that those intentions ignore "values now cherished in our society and . . . produce decidedly farfetched or unacceptable results."338

Notwithstanding these admonitions and the Court's statements, if neutrahty implies the equal treatment of all beliefs, whether rooted in religion or not, it provides an inadequate foundation on which to base Estabhshment Clause jurisprudence. The concept of neutrality requires judicial definition both of equal standing and of equal treatment. But the search for these definitions is futile.

The first problem is defining equal standing. ${ }^{339}$ Borrowing from equal protection doctrine, the Court has concluded that people of different behiefs are "similarly situated" for Establishment Clause purposes, and are therefore entitled to similar treatment. ${ }^{340}$ However, determining when institutions, as opposed to people, are similarly situated is more difficult. $^{341}$ The criteria employed to compare institutions could simply parallel those employed to compare individuals. Thus, institutions embodying different behiefs could be deemed "similarly situated" for Estabhshment Clause purposes. This approach is faulty, lowever, because institutions probably have certain characteristics that individuals do not have-characteristics that should affect the determination of what is "similarly situated." The task of articulating what constitutes institu-

\footnotetext{
Religion according to the dictates of conscience." Whilst we assert for ourselves a freedom to embrace, to profess and to observe the Religion which we believe to be of divine origin, we cannot deny an equal freedom to those whose minds have not yet yielded to the evidence which las convinced us.
}

Id. at 301 (footnote omitted).

336. See Adams \& Emmericl, supra note 303, at 1639-40 (arguing that a proper reading of listorical evidence suggests that "the central feature of an establishment was governmental coercion of conscience").

337. See, e.g., Gillette v. United States, 401 U.S. 437, 449 (1971) ("An attack founded on disparate treatnient of 'religious' claims invokes what is perliaps the central purpose of the Establishment Clause-the purpose of ensuring governmental neutrality in matters of religion."); School Dist. v. Scliempp, 374 U.S. 203, 225 (1963) ("[T] he government [niust] maintain strict neutrality, neither aiding nor opposing religion."); see also Steve Gey, Note, Rebuilding the Wall: The Case for a Return to the Strict Interpretation of the Establishment Clause, 81 CoLUM. L. REv. 1463, 1484-85 (1981) (arguing for strict neutrality in interpreting the Establisliment Clause). But see Walz v. Tax Comm'n, 397 U.S. 664, 669 (1970) (Neutrality "cannot be an absolutely straiglit line; rigidity could well defeat the basic purpose of [the Religion Clauses], which is to insure tlat no religion be sponsored or favored, none commanded, and none inlibited").

338. Choper, supra note 303, at 333 (footnote omitted).

339. For an insightful discussion of this problem, see Lieder, supra note 333, at 873-77.

340. Id. at 873 .

341. Id. at 874 . 
tional similarity, though not impossible, would clearly require more than current, individual-focused equal protection theory provides.

A second, and more fundamental, problem is deciding what constitutes similar treatment of people or institutions that are deemed similarly situated. One possible conception of equal treatment is giving no aid to religion that is not given to nonreligion, and vice versa. Under this approach, the government's safest course is to avoid all contact with both religion and nonreligion because such contact miglit risk aiding one side or the other. By avoiding any effect on either religion or nonreligion, the government would act only in what miglit be called the exclusively "secular" sphere.

This approach is unsatisfactory in two respects. First, it requires a court to define religion in order to delineate the spheres of "religion" and "nonreligion." Unfortunately, there is widespread disagreement about how "religion" should be defined. ${ }^{342}$ Adopting a definition advocated by any one person or one group risks subjecting some arguably religious beliefs, but not others, to the burdens of the Establishment Clause. This disparity would violate the notion that similarly situated groups or beliefs should be similarly treated.

Second, and more fundamentally, the equal protection analysis assumes that some beliefs are neither religious nor nonreligious. ${ }^{343}$ This assumption is untrue. While it is true that not all nonreligious beliefs are

342. There is an extensive body of literature on the problem of defining religion. See Jesse H. Choper, Defining "Religion" in the First Amendment, 1982 U. ILL. L. REV. 579 (attempting to formulate a definition of religion under the Free Exercise Clause); Kent Greenawalt, Religion as a Concept in Constitutional Law, 72 CALIF. L. REv. 753, 815 (1984) (suggesting that courts should determine what is "religious" by analogizing witl what can be defined as "undeniably religious"); Johnson, supra note 330, at 831-39 (discussing the impossibility of adequately defining religion); Timothy L. Hall, Note, The Sacred and the Profane: A First Amendment Definition of Religion, 61 TEX. L. REV. 139 (1982) (defining religion as a way of perceiving reality that contains elements that are both sacred and profane); Note, Toward a Constitutional Definition of Religion, 91 HARv. L. REv. 1056 (1978) [hereinafter Toward a Constitutional Definition] (proposing a bifurcated definition of religion with reference to the two Religion Clauses in the First Amendment).

A major debate among these scholars focuses on whether religion should be defined functionally-in terms of the "ultimate" or "overriding" character of one's beliefs-or based on content, such as a belief in a deity. My own view is that a functional definition best reflects the conception that the framers had in mind when drafting an amendment to protect conscientiously held beliefs. A comprehensive definition of religion, however, is beyond the scope of this Comment and is not necessary for the argument advanced here.

343. See Grove v. Mead Sch. Dist. No. 354, 753 F.2d 1528, 1536 (9th Cir.) (Canby, J., concurring) (cliallenge by rehigious family to a book in the public high school curriculum), cert. denied, 474 U.S. 826 (1985). Judge Canby asserts that "secular" does not mean anti-religious, and therefore that the Establishment Clause does not forbid the public schools from promoting secular values over religious ones. Id. at 1541 . This contention is part of his argument that courts should not treat "secular liumanism" as a religion in the same way that, for example, they do Christianity. Id. at 1537. One can note, however, the differences between secular lumanism and other religions witlout assuming that what is "secular" is "neutral" in the sense of being neither religious nor nonreligious. 
anti-religious, all beliefs are either consistent with the tenets of a religion or they are not.

How religion is defined will affect the types and the number of people and activities that are "religious" for constitutional purposes. If religion is defined functionally-as a belief system rooted in "ultimate concerns" or "values" or some guiding principle or set of principles that are deemed umversal ${ }^{344}$-then anyone lolding such beliefs is "religious" and anyone not lolding such beliefs is "not religious." Similarly, if religion is defined operationally, according to the cliaracteristics of the institutions surrounding beliefs and the formalization of beliefs through ritual and symbolism, ${ }^{345}$ then only those whose beliefs are formalized according to the operational criteria are religious. If the defimition is content-based so that, for example, only theistic beliefs are "religious,"346 then only those believing in God might be called religious. The possible criteria suggested liere are less important than the fact that it makes little sense to describe a belief as neither religious nor nonreligious. ${ }^{347}$ If the government acts consistently with either a religious or nonreligious belief, then it necessarily benefits one belief system relative to another.

The conception of equal treatment miglit be modified in one of several ways. One approach would be to require equalization of benefits and burdens for people of all beliefs, whether grounded in religion or not. However, this possibility cannot be correct. No one seriously contends, for example, that if the government spends money on agriculture or national defense, then it must also give equal money to a religious organization. ${ }^{348}$ This is true even though agriculture and national defense further certain goals that are consistent witl some belief systems and inconsistent with others. An absolute regime of equal treatment, then, would require the government to aid all institutions and all individuals-

344. See, e.g., Toward a Constitutional Definition, supra note 342, at 1066-67.

345. See, e.g., id. at 1086-87.

346. See, e.g., United States v. MacIntosh, 283 U.S. 605, $633-34$ (1931) (Hughes, C.J., dissenting) ("The essence of religion is belief in a relation to God involving duties superior to those arising from any luman relation.").

347. See Grove, 753 F.2d at 1536 (Canby, J., concurring). Writers have also posited the existence of a "nonreligious" category that is not necessarily anti-religious. See Developments in the Law-Religion and the State, 100 HARv. L. REv. 1607, 1670-74 (1987) [hereinafter Developments]. This suggestion supports the argument that fundamentalist religious sects should not be allowed to object under the Establishinent Clause when schools inculcate values such as equality and tolerance, because these democratic values are bound to be antithetical to religious, "absolutist noralities ... [which] by definition do not tolerate dissent on moral questions." Id. at 1671 n.159. However, the extent to which religious ideology tolerates dissent is irrelevant to the question of whether government action is neutral with respect to values. Even if one agrees that the government should be allowed to instill values that are considered sacred to deinocracy, it is unreasonable to pretend that the process of instilling those values does not amount to identification with any belief.

348. See Steven D. Smith, Symbols, Perceptions, and Doctrinal Illusions: Establishment Neutrality and the "No Endorsement" Test, 86 MiCH. L. REv. 266, 330 (1987). 
religious and nonreligious-whenever it chooses to aid any one institution or individual.

A second inodified conception of equal treatment focuses on motivation. Equal treatment of religion and nonreligion would be action that is not motivated by differences in behefs. This definition comports well with individualism because it views people independently of their membership in a rehigious group. ${ }^{349}$ However, even if ideology could be excised from the legislative process altogether, the effect of a government action cannot be called "neutral" if some groups benefit more than otliers or if the action is contrary to certain individuals' behefs. ${ }^{350}$

It might be argued that a conception that focuses entirely on motivation deems effects irrelevant. Under such a conception, it would not matter that some behef systems benefit more than others as long as the government's intention is not to prefer one behef over another. However, because any government action may be traced to some moral objective, and because no moral objective is consistent with all behefs, ${ }^{351}$ preferring one or inore behefs over others is inevitable.

A final possible conception of equal treatment focuses on the preservation of equal religious freedom. Professor Ira Lupu argues that this kind of equality is one of the core values that the Religion Clauses are desigued to protect. ${ }^{352}$ Although this notion, in the abstract, is accurate, Lupu appears to include tangible benefits and burdens under the heading "liberty." 353 Under this conception, whatever kind and degree of liberty

349. This definition is analogous to Justice O'Connor's view that equal protection principles command that government action not take race into account at all. See Metro Broadcasting, Inc. v. FCC, 497 U.S. 547, 619-23 (1990) (O'Connor, J., dissenting).

350. See Lieder, supra note 333, at 876-77. Although the Supreme Court has rejected explicitly the proposition that a government action violates either the Equal Protection Clause or the Due Process Clause "solely because it has a racially disproportionate impact," Washington v. Davis, 426 U.S. 229, 239 (1976), the Court has never contended-in Washington or in any other case-that government actions having such disproportionate impacts are necessarily "neutral." It has concluded inerely that the kind of non-neutrality manifested through disproportionate inpact is acceptable nnder the Fourteenth Amendment.

351. It may be true that a government based on notions of individualisin assumes that those notions are consistent with the beliefs of all who choose to remain nembers of the society. Government conduct based on this assumption, however, cannot be justified with reference to any notion of ideological neutrality. It must instead be justified with reference to some independent goal such as maintaining the legitimacy of the government by making good on the state's pronise to use its power to protect individual rights. This goal may or may not be consistent with a particular rehigious or nonreligious belief; that consistency matters only if neutrality is the Establishment Clause's touchstone for government conduct.

352. Ira C. Lupu, Reconstructing the Establishment Clause: The Case Against Discretionary Accommodation of Religion, 140 U. PA. L. REV. 555, 567-70 (1991).

353. See id. at 558 ("If, however, accommodation represents a set of ideas driven by zeal for religious liberty and is consequently insensitive to concerns for equal respect in the actual distribution of such hiberty, the concept bears within it the seeds of great harm.") (emphasis added). Professor Lupu's emphasis on distribution suggests a concern that the government do more than merely refrain from interfering with individuals' voluntary religious choices. Indeed, it suggests that when the government acts, it must act in such a way that rehigion and nonreligion are actually 
that is granted to one belief system must be granted to all. Unfortunately, this positive conception of hiberty carries with it the same analytical difficulties as the conception of equality that posits equal distribution of benefits and burdens: $:^{354}$ there is no way to ensure equal distribution of benefits and burdens across all belief systems.

In contrast, the conception of hiberty envisioned in this Comment is negative: the state must act in ways that protect, and refrain from acting in ways that threaten, the rehigious liberty of eacli individual. Although the right to be free from religious discrimination is part of that liberty under the contractarian model, the equalization of benefits and burdens is not. Equality merely describes low the underlying value-religious liberty-should be realized.

Individual religious liberty, then, appears to be the primary value underlying the Establishment Clause. Accordingly, it should play a prominent role in guiding interpretation of the Clause. Further, when rehigious liberty conflicts witl other proposed values underlying the Clause, rehigious liberty slould take precedence.

\section{The Principle of Religious Liberty as the Sole Guide to Constitutional Interpretation: The Inadequacy of Original Intent}

Even if individual rehgious liberty should help guide the interpretation of the Establishment Clause, does it necessarily follow that it should be the sole, or even the primary, guide to such interpretation? It might be argued that the framers' intent provides a inore desirable basis for such interpretation than any substantive value that the Clause seeks to protect. Original intent, lowever, does not provide adequate guidance for Establishment Clause interpretation because the nation's political and cultural landscape has changed so drastically over the last two hundred years. Govenmient actions that were perfectly acceptable at the time the First Amendment was written are simply unacceptable in today's religiously heterogeneous society. Given the insufficient guidance from original intent, the theoretical guidance provided by the goal of religious liberty is particularly important for understanding the Establishment Clause.

Original intent's first shortcoming lies in the definition of "establishment." There is little controversy over the proposition that the

affected equally. If Lupu means merely that rights must be granted equally, then we are in agreement. For example, I would deem invidious discrimination along religious lines impermissible. Although it does not necessarily interfere with physical freedom to worship or compel individuals to attend a state-established church, it does violate the right of the disadvantaged individuals not to be respected any less or be treated any worse by the state because of their religion than they otherwise would be. Thus, the state would have to choose between conferring the benefit or imposing the burden according to soine acceptable criterion and not acting at all.

354. See supra text accompanying note 348 . 
term means more than merely setting up a national church and forcing citizens to attend. At a minimum, "establishment" encompasses government discrimination in favor of particular rehgious sects and against otlier sects. ${ }^{355}$ The paradigmatic example of this kind of discrimination is the collection of taxes on behalf of a particular sect. There is significant evidence that the framers in general and Madison in particular feared this kind of discrimination. ${ }^{356}$

However, the framers were not universally suspicious of the kinds of official acknowledgment of religion that liave been cliallenged in the past twenty years. For example, neither Jefferson nor Madison objected to the official proclannations of days of thanksgiving and prayer to God that were common in the states two centuries ago. ${ }^{357}$ Similarly, prayer by government-sponsored chaplains in state and federal legislative sessions was commonly accepted. ${ }^{358}$

History suggests that these practices were never challenged because American society was previously inore religiously lomogeneous than it is today. Furtlier, some forms of religious acknowledgment, such as elaborate Christmas displays on the steps of imposing state-funded structures, may not even liave existed 200 years ago. Uplolding certain acknowledgment practices merely because they used to be accepted and then atteinpting to analogize tliose practices to contemporary practices that were never conteinplated two centuries ago leads to the kinds of glaring inconsistencies that cliaracterize current Establishment Clause law. Legal pragmatisnı requires a jurisprudence that botlı flows from the framers' concerns and applies to situations that the framers did not conteinplate. ${ }^{359}$

The second slortcoming is the lack of guidance about who may and who may not establish a religion. There is persuasive evidence that the framers souglit only to prevent the federal governinent froin "establisl1mg" a cliurch against the will of the individual states. ${ }^{360}$ Indeed, the Clause's wording arguably reflects this intent. For example, the word "respecting" ineant "for or against," ratler than "tending to."361 The framers wanted to prevent the federal government not only fronı establishing a national cliurch, but also from interfering witl existing estab-

355. See DreisBach, supra note 287 , at 54 (noting that "nonpreferentialists" read the Establishınent Clause as forbidding only the preference of one religious sect over another).

356. See id. at 139-58.

357. Id. at 108-11.

358. See Marsh v. Chambers, 463 U.S. 783, 787-90 (1983) (recounting the strong historical tradition of prayers in state legislatures and Congress).

359. Under this approach a court, recognizing that individual religious liberty was parainount among the framers' conccrns, see supra text accompanying notes 286-90, inay proceed to invalidate some practices in today's social context that the framers allowed in theirs.

360. See DREISBACH, supra note 287 , at 69-82.

361. Id. at 79-80. This interpretation is contrary to Chief Justice Burger's assertion in Lemon v. Kurtzman that "respecting" ineans a "step in the direction of." 403 U.S. 602, 612 (1971). 
lished churches in the states. ${ }^{362}$

The Court, however, has rejected the idea that the states may establish official churches. ${ }^{363}$ State establishments of religion today, unlike state estabhishments 200 years ago, pose as great a risk to religious hiberty as does federal establishment. State governments now regulate an increasing number of private activities. ${ }^{364}$ Since state substantive policies are likely to be expressed through these new regulations, a state estabhishment of religion potentially affects individuals' hives in direct, concrete ways.

The final shortcoming focuses on the Establishment Clause's conception of "rehigion." 365 There is a great deal of historical evidence that the frainers sought inerely to prevent preference of one rehigious sect over another-not preference for religion in general over nonreligion. ${ }^{366}$ The wording of the Estabhshment Clause arguably reflects this intention also. The word "an" preceding "establishment" may reflect an intention to forbid inerely preference of one religious sect. If the intent were to forbid preference for religion over nonreligion, the drafters should have chosen the word "the" or inserted no article at all before the word "religion."367 The Supreine Court, however, has rejected this interpretation, which would allow discrimination against nonreligion. ${ }^{368}$ This rejection seens proper in hight of the First Amendinent's premiun on freedoin of conscience. Just as Locke's principles can include atheists without sacrificing the internal logic of his argument, ${ }^{369}$ the Establishment Clause can and should protect rehigious hiberty in a society where inany people exercise that liberty by choosing not to be rehigious.

362. DREISBACH, supra note 287 , at $79-80$.

363. See supra notes 310-11 and accompanying text.

364. Cf. Michael W. McConnell, Neutrality Under the Religion Clauses, 81 Nw. U. L. REV. 146, 161 (1986) (arguing that neutrality with respect to rehgion is improper where government presence $\mathrm{m}$ a sphere of private activity is pervasive).

365. For literature on the problem of defining rehgion, see sources cited supra note 342 .

366. See DREISBACH, supra note 287 , at 74-75.

367. Id. at 65; see also Rodney K. Smith, Getting off on the Wrong Foot and Back On Again: $A$ Reexamination of the History of the Framing of the Religion Clauses of the First Amendment and a Critigue of the Reynolds and Everson Decisions, 20 WAKE FOREST L. REV. 569, 608-13 (1984) (recounting the debates in the House of Representatives in 1789 regarding the phrasing of the Establishment Clause and indicating that these alternative phrasings werc considered).

368. See Everson v. Board of Educ., 330 U.S. 1, 15-16 (1947); see also Torcaso v. Watkins, 367 U.S. 488, 492-93 (1961) (citing Everson and reaffirming the Everson Court's interpretation of the Estabhishment Clause); McCollum v. Board of Educ., 333 U.S. 203, 210 (1948) (same).

369. See supra text accompanying notes $282-83$. 


\section{IV}

\section{DISJUNCTURE BETWEEN THEORY AND LAW: INABILITY OF EXISTING Establishment Clause Tests to ENSURE RELIGIOUS LIBERTY}

If religious liberty is central to the Establishment Clause, then the desirability of current Establishment Clause tests sliould be measured according to how well the tests ensure this liberty. This Part will demonstrate that the two most popular tests embraced by the Court-the Lemon test and the endorsement test-do not protect religious liberty. These tests are problematic because they assess government threats to equality - a value totally different from and, in some cases, at odds witll-liberty.

\section{A. The Lemon Test: The Impossibility of Strict Neutrality}

Despite its theoretical and practical shortcomings, the principle of neutrality lias driven many of tlie Court's Establishment Clause decisions. The Lemon test ${ }^{370}$ in particular strives to approximate equalization of bnrdens and benefits between religion and nonreligion. Simce the Court in fact cannot achieve this equalization, it lias instead made caseby-case judgments about what benefits to religion are unacceptable. While it miglit be argued that this attempt at complete neutrality is better than no atternpt at all, an examination of the Lemon test's effects prong suggests that the test actually threatens religious liberty instead of ensuring it. ${ }^{371}$

\section{The Effect Prong of the Leinon Test}

The second prong of the Lemon test requires that the "primary effect" of the government action "be one that neither advances nor inhibits religion." 372 This requirement supposedly falls short of prohibiting any government action tliat confers some benefit or imposes some burden on religion. ${ }^{373}$ However, a precise definition of "primary effect" lias remained elusive.

The Court could assess the "primary effect" quantitatively. Sucl an approach imight prohibit government action that "substantially aid[s]" religion. ${ }^{374}$ Altlrough the Court has based several decisions on the objec-

370. Lemon v. Kurtzman, 403 U.S. 602, 612-13 (1971); see supra text accompanying notes 1-6.

371. This discussion focuses on the effect prong because that is where the primary shortcomings appear. Although there may be additional problems with Lemon's purpose test, it is not necessary to consider them here because Lemon's test is conjunctive, and therefore the deficiencies of one prong infect the entire test.

372. Lemon, 403 U.S. at 612.

373. See, e.g., Mueller v. Allen, 463 U.S. 388, 393 (1983) (noting that the Court has consistently rejected the argument that " 'any program which im some manner aids an imstitution with a religious affiliation' violates the Establishment Clause" (quoting Hunt v. McNair, 413 U.S. 734, 742 (1973)).

374. See Lynch v. Donnelly, 465 U.S. $668,682-83$ (1984). 
tive degree of a government action's effect on religion, it lias rejected a quantitative approach in inost cases. ${ }^{375}$ The fundainental problein with this objective approach is that it deprives the word "primary" of its relativity coinponent. ${ }^{376}$ The word "primary" suggests tliat tlie courts must determine whetler a government action's benefit to religion is more substantial than the action's benefit to secular objectives.

Anotlier possible approach to the "primary effect" prong is a requirement that the government action's advancement or inlibition of rehgion be less pronounced than some other effect. This approach would require an assessment of the relative magnitude of benefits and burdens. That assessment, im turn, would require a basis for comparing magnitudes of benefit. ${ }^{377}$ The Court lias never undertaken this formidable task and, as Professor Steven Smitli points out, it sliould not be expected to do so. ${ }^{378}$

A tliird possible formulation of "primary effect"-implicitly adopted by the Court-is that the challenged government action must not inake the benefit to or the burden on religion a necessary condition for the realization of the legitimate secular purpose. ${ }^{379}$ If the government action does not mclude such a condition, the Court cliaracterizes the aid to religion as merely "incidental." 380

Unfortunately, the Court's decision about whether the government in fact lias created this necessary condition has consisted of ad lioc determinations that reveal the Court's desire to use Lemon to approximate a coinplete equalization of benefits and burdens. For example, in the inajor cases involving aid to parochial scliools, the Court's effects analy-

375. See supra Section II.A (discussing the Supreme Court's decisions in cases involving economic assistance to religion); see also Mueller, 463 U.S. at 401 ("We would be loath to adopt a rule grounding the constitutionality of a facially neutral law on annual reports reciting the extent to which various classes of private citizens claimed benefits under the law.").

376. This relativity component is built into any accepted definition of the word. It implies that something is first or most important among several possibilities.

377. Possible bases include the total amount of money at issue, the ratio of money to the number of people in each category, the ratio of money to the aggregate need of people in all categories, or the incrcase in the welfare of the people in each category (here, the term "welfare" would require a workable definition). See Smith, supra note 348 , at 330 .

378. Id. The Court could also assess effect with reference to the purposes of the government action. Under this formulation, if the Court determines that the "primary" purpose is religious, then the effect is impermissible. However, this meaning would render Lemon's effect prong superfluous.

379. See, e.g., Witters v. Washington Dep't of Servs. for the Blind, 474 U.S. 481,486 (1986) (stating that "the Establishment Clause is not violated every time money previously in the possession of a State is conveyed to a religious institution"); see also McGowan v. Maryland, 366 U.S. 420, 442 (1961) ("[T]he 'Establishment' Clause does not ban federal or state regulation of conduct whose reason or effect merely happens to eoincide or harmonize with the tenets of some or all religions.").

The word "make" in the text of my argument is particularly important. If the government sets out to accomplish a secular purpose, and aid to religion happens to be necessary to accomplish that purpose, then the government cannot be said to have created the dependency. Therefore, the government cannot be accused of using religion as a vehicle of public policy.

380. Committee for Pub. Educ. \& Religious Liberty v. Nyquist, 413 U.S. 756, 771 (1973). 
sis consists primarily of attempts to separate the schools" "secular" and "religious" activities in order to ensure that state funds are not used to fund anything explicitly religious. ${ }^{381}$ This analysis ignores the financial reality that whetler tlie state funds are used for explicitly religious activities or not, the money mevitably "benefits rehgion" by relieving parochial scliools of expenses that they otherwise would have to bear. ${ }^{382}$

The Court may be more concerned in these cases about the "symbohic" alliance between church and state when the state funds exphicitly religious activities. ${ }^{383}$ The language and the logic of the Lemon test, however, make no distinctions about wliat kind of "advancement" of religion is impermissible. The lines that the Court lias tried to draw between permissible and impermissible benefits to religion under the Lemon test do not seem to be rooted directly in any self-evident definition of the words of the Lemon test or in any general principles that the Lemon test purports to uphold.

\section{The Lemon Test as a Threat to Religious Liberty}

Given these parameters, the first way that the Lemon test comproimses religious liberty is by denying the kinds of religious accommodation that the Free Exercise Clause appears to require. Indeed, if the Lemon criteria are applied strictly, the Free Exercise Clause itself might be said to violate the Establishment Clause, smce any government action or omission based on the Free Exercise Clause is necessarily rooted in a religious purpose. Further, because the Free Exercise Clause seeks specifically to protect rehgious activities, regulatory exemptions motivated by Free Exercise concerns inevitably benefit rehgion by exempting members of a religious group from an otherwise generally applicable law that somehow inpedes their religious activity.

One possible solution to this problein is to create an exception to the Lemon test in cases where tlie Free Exercise Clause compels a different

381. See, e.g., Aguilar v. Felton, 473 U.S. 402,409 (1985); School Dist. v. Ball, 473 U.S. 373, 386-89 (1985), overruled by Bowen v. Kendrick, 487 U.S. 589 (1988); Wolman v. Walter, 433 U.S. 229, 236-55 (1977); Nyquist, 413 U.S. at 774-94; Lemon v. Kurtzman, 403 U.S. 602, 615-22 (1971).

382. Although the Court in these cases is arguably trying to ensure that state money is not used for explicitly religious activities instead of the secular activities for which the funding is provided, the Lemon test seems to reveal a more general fear of excessively benefitting religious institntions, whether that benefit uses up money designated for secular activities or not.

Economists would agree that any grant of useful goods or services expands the recipient's budget for other goods. Thus, when a parochial school receives useful "secular" goods or services from the government, it will increase its spending on other items, including "religious" activities. Cf. Lee S. Friedman, Microeconomic Policy ANalysis 99-101 (1984) (demonstrating that even if a federal grant to a community is earmarked for the local government, the commurity's response will be to spend more on private, non-government "goods").

383. See Ball, 473 U.S. at 390 ("[A]n important concern of the effects test is whether the symbolic union of church and state effected by the challenged governmental action is suffiently hikely to be perceived by adherents of the controlling denominations as an endorsement, and by the nonadherents as a disapproval, of their individual religious choices."). 
result. Simply creating this exception, however, would not provide any criteria to determine when the Estabhishment Clause should be suspended in favor of the Free Exercise Clause. In addition, determining the scope of the Free Exercise Clause in this context would become a matter of characterization. ${ }^{384}$ Further, soine might choose to subordinate the Free Exercise Clause to the Establishment Clause when the two conflict.

Although the Court has not extended Lemon to the point of eviscerating the Free Exercise Clause, the Lemon criteria still create an intolerable threat to religious liberty. For example, a strict application of the Lemon test would prohibit the government from granting an exeinption froin Sunday closing laws for a person whose Sabbatls falls on a day other than Sunday. The purpose of such an exeinption would be predominantly, if not exclusively, religious. This fact alone would render the exemption invalid under Lemon's purpose prong. ${ }^{385}$

Similarly, a strict application of the Lemon test would bar the government from granting a religious exeinption from laws forbidding the use of certain drugs. This application of the Lemon test would yield the same result that Justice Scalia reached in Employment Division, Oregon Department of Human Resources v. Smith ${ }^{386}$ - that the Free Exercise Clause does not require a cereinomial-use exeinption from laws banning the use of peyote. In addition, such an exeinption would presuinably violate the Establishment Clause because it is given for purely religious purposes.

Even minor exemptions would be forbidden under a strict application of Lemon. As Professor Jesse Choper suggests, an exeinption for rehigious reasons from a public school regulation requiring pliysical education students to wear short pants would fail a test, like Lemon, that is grounded in strict neutrahity. ${ }^{387}$ Choper correctly notes that simply broadening the exemption to mclude nonreligious reasons is problematic because the more the exemption is broadened, the less effectively the rule accomphishes the purpose for which it was designed. ${ }^{388}$

Of course, the Court lias not always apphed Lemon so strictly. In cases such as Marsh v. Chambers, ${ }^{389}$ in which the constitutionality of legislative prayer was cliallenged, the Court simply could not accept the results that a strict application of Lemon would have required. ${ }^{390}$ The

384. See Johnson, supra note 330, at 821-22 (arguing that "many significant problems can be categorized so as to fall under the rule of either the establishment clause or the free exercise clause").

385. See supra text accompanying notes 1-3.

386. 494 U.S. 872 (1989).

387. Choper, supra note 315 , at $688-89$.

388. Id.

389. 463 U.S. 783 (1983).

390. See id. at 796-97 (Brennan, J., dissenting) (noting the majority's outright refusal to apply the Lemon test to the practice of legislative prayer). 
Court's exercise of discretion, however, is not a forceful argument in favor of the Lemon test. A test that is simply ignored when it produces unacceptable results is not very useful.

A second, more fundamental way that the Lemon test threatens rehgious liberty is by preferring nonrehgion over rehion. Under the Lemon approach to the Establishment Clause, "religion" seems to mclude only traditionally recognized religions, many of whiclı are theistic. Althouglı tlie Supreme Court has recognized explicitly that "rehion" includes non-tlieistic beliefs, ${ }^{391}$ most Establishment Clause clrallenges have focused on practices of theistic religions ${ }^{392}$ and cliallenges to the "establishment" of non-theistic beliefs liave been rejected by lower federal courts. ${ }^{393}$ The Lemon test, therefore, does not appear to concern itself witl belief systems, such as humamism, that can be incompatible witli or antithetical to traditional religious beliefs.

Some commentators argue tliat this narrow, content-based definition is desirable in the Establishment Clause context while a broader, functional definition is desirable in the Free Exercise Clause context. ${ }^{394}$ For example, Professor Laurence Tribe has observed that if rehigion were defined functionally under the Establishment Clause, government action designed to advance democratic values like "'luman dignity, equality, national destiny, freedom, enlighteument, and morality" "might be invalid. $^{395}$ Tribe once argued that a dual definition was desirable to avoid striking down these kinds of government actions. ${ }^{396}$

Accordingly, one writer lias suggested that while religion under the Free Exercise Clause sliould be defined broadly, religion under the Establishment Clause should be defined by three "operational criteria": orgamization, theology, and attitudimal conformity. ${ }^{397}$ Organization

391. See Torcaso v. Watkins, 367 U.S. 488, 495 n.11 (1961) ("Among religions in this country which do not teach what would generally be considered a behef in the existence of God are Buddhism, Taoism, Ethical Culture, Secular Humanism and others."). But see Grove v. Mead Scli. Dist. No. 354, 753 F.2d 1528, 1537 (9th Cir.) (Canby, J., concurring) (arguing that the reference to "secular humanism" refers ouly to a group of people who engage in ceremonial belavior similar to that of theistic religions, but who are not really religious), cert. denied, 474 U.S. 826 (1985).

392. See, e.g., Edwards v. Aguillard, 482 U.S. 578 (1987) (finding Louisiana's "Creationism Act" unconstitutional); Epperson v. Arkansas, 393 U.S. 97 (1968) (finding Arkansas' "antievolution" statute unconstitutional).

393. See, e.g., Grove, 753 F.2d at 1534 (rejecting an Establishment Clause challenge to public school use of a book that promoted "secular humanism").

394. A "functional definition" is one that focuses on the ultimate or overriding quality of values or concerns rather than the specific content of those concerns. See, e.g., Toward a Constitutional Definition, supra note 342, at 1066-67.

395. Laurence H. Trube, american Constitutional Law 831 (1st ed. 1978) (quoting Marc Galanter, Religious Freedom in the United States: A Turning Point?, 1966 Wis. L. REV. 217, 266).

396. Id. Professor Tribe las since changed his position on this point, arguing that a dual definition may not be desirable after all. Laurence H. Tribe, American Constiturional Law 1186 (2d ed. 1988).

397. See Toward a Constitutional Definition, supra note 342, at 1087. 
refers to institutional characteristics, such as the number of adherents, the stability of the association, and the presence of channels of authority. ${ }^{398}$ Theology refers to the "comprehensiveness" of the belief system and ceremonial behaviors designed to formalize those beliefs. ${ }^{399}$ Conformity refers to homogeneity of the group and the prominence of those shared beliefs in individuals' lives. ${ }^{400}$

These operational criteria, however, are more likely to describe traditional religious sects than many non-tlieistic, nontraditional, minority belief systems, even though the latter group might be considered religious under a broader definition. As Professor Phillip Johnson notes, under this dual-definition approach to the Rehgion Clauses, people fitting into this non-theistic category might obtain the protection of the Free Exercise Clause without mcurring the burdens of the Estabhshment Clause. ${ }^{401}$

Because the Religion Clauses were motivated in part by a desire to protect religious minorities and dissenters from persecution and coercion by the majority, it miglit be argued that this disproportionate distribution of benefits is justified in liglit of the listory of discrimination against religious minorities. This distribution, lowever, violates the fundamental individualist values underlying the First Amendment. The Religion Clauses were designed to ensure the equal religious freedoin of every individual, not just the religious freedom of minority religious groups. ${ }^{402}$ Restricting the application of a standard as strict as the Lemon test to only a select group of belief systems is a paradigmatic violation of freedom of conscience.

\section{B. The Endorsement Test: The Unfulfilled Promise of Symbolic Neutrality}

In Lynch v. Donnelly, ${ }^{403}$ Justice O'Connor proposed a "clarification" of the Lemon test. ${ }^{404}$ Her resultimg "endorsement" test focuses on symbolic neutrality rather than equalization of tangible benefits and burdens. ${ }^{405}$ This new test, however, is no more desirable than the Lemon test because it camiot be administered effectively and because it does not gnard individual religious liberty.

398. Id.

399. Id. It is interesting that "comprehensiveness" sounds inuch like a functional criterion; however, this discussion accepts that the commentator does not wish to einploy a functional definition and therefore focuses inore on the formalization and institutionalization of beliefs than on the characteristics of those beliefs.

400. Id.

401. Johnson, supra note 330 , at 835 ; see also Greenawalt, supra note 342 , at 814 .

402. Johnson, supra note 330 , at $\mathbf{8 3 5}$.

403. 465 U.S. 668 (1984).

404. Id. at 687 (O'Connor, J., concurring).

405. See id. at 692 . 


\section{Dimensions of the Endorsement Test: Lynch v. Donnelly}

Although Justice O'Connor's endorsement test parallels the structure of the Lemon test and claims merely to give content to the terms "advance" and "inhibit," it actually deviates substantially from Lemon. The test is similar to Lemon only in that it seeks to identify the purpose and primary effect of a government action. Indeed, O'Connor's original formulation was circumscribed by the language of Lemon's first two prongs:

The purpose prong of the Lemon test asks whether government's actual purpose is to endorse or disapprove of rehigion. The effect prong asks whether, irrespective of government's actual purpose, the practice under review in fact conveys a message of endorsement or disapproval. An affirmative answer to either question should render the challenged practice invalid. ${ }^{406}$

The similarities between O'Connor's test and the Lemon test end here. First, the endorsement test strives not for a government that equally distributes benefits and burdens, but rather for a government that does not appear to approve of one behef over another. Although governinent need not aid all behef systeins equally, it inust convey equal approval of all religious and nonrehigious behiefs. ${ }^{407}$

Second, unlike the Lemon test, the endorsement test measures the relevant neutrality of the government's action through the eyes of someone other than the judge. In Justice O'Counor's original formulation of the endorsement test, symbolic neutrality is measured through the eyes of the actual observer. ${ }^{408}$ In a more recent formulation, it is ineasured through the eyes of the "objective observer." 409

The objective observer is fictitious rather than empirical. This observer is a construct whose characteristics are predetermined by the judge. Accordingly, some of the observer's further characteristics can be extrapolated froin Justice O'Connor's general sketch. First, the objective

406. Id. at 690 .

407. Justice O'Connor is not entirely clear on this point. It is possible that she would favor endorsement of nonreligious beliefs but forbid endorsement of religious beliefs. Of course, this onesided formulation would be inconsistent with her stated rationale-that endorsement of one belief system over another sends a message to those whose behiefs are not endorsed that they are somehow "outsiders." See id. at 688 . This rationale logically applies with equal force to all beliefs-religious and nonreligious.

408. According to Justice O'Connor:

The meaning of a statement to its audience depends both on the intention of the speaker and on the "objective" ineaning of the statement in the commumity. . . . If the audience is large, as it always is when government "speaks" by word or deed, soine portion of the audience will inevitably receive a message determined by the "objective" content of the statement, and some portion will inevitably receive the intended message.

Id. at 690 .

409. Wallace v. Jaffree, 472 U.S. 38, 76 (1985) (O'Connor, J., concurring in the judgment) ("The relevant issue is whether an objective observer ... would perceive it as a state endorsement ...."). 
observer should not necessarily act like most people in the community; otherwise, the observer would embody nothing more than the values of the majority and the observer's judgments might not be sensitive to government disapproval of minority rehigions.

Second, the objective observer probably possesses the knowledge and experience of the judge. According to Justice O'Connor, the objective observer knows the "text, legislative history, and implementation of the statute." 410 Presumably, these characteristics enable the objective observer to arrive at a more defensible conclusion-one that can be verified by looking at the context in which the law was made and apphed.

Finally, the objective observer should embody the concern for rehgious hiberty that underlies the Estabhishment Clause. Accordingly, the objective observer should be sensitive to the concerns of rehigious minorities even though the observer's point of view cannot necessarily be equated with theirs. ${ }^{411}$

\section{Deficiencies in the Endorsement Test}

Unfortunately, the endorseinent test is no inore suited than the Lemon test to protecting religious hiberty. It is hard to define Justice O'Connor's terms in a way that will effectively identify government threats to actual rehigious hiberty. Moreover, because the endorsement test-like the Lemon test-strives for equality rather than liberty, it inay actually threaten rehigious hiberty in some cases.

\section{a. Terminology Without Content: The Insurmountable Barrier to Implementation}

The endorseinent test employs concepts that are so ambiguous that the test cannot be administered. The first troubling concept is "endorsement" itself. None of the opinions employing the concept provide an adequate definition of endorsement. The term is difficult to define because it rests fundamentally on the empty concept of neutrality.

As Professor Steven Sinith points out, the endorsement test attempts to avoid the problem of articulating a coherent conception of neutrality by striving merely for the appearance of neutrality. ${ }^{412}$ According to this argument, a statement of fact about the external world inay be wrong

410. Id.

411. Justice O'Connor notes:

Direct government action endorsing religion or a particular religious practice is invalid under [the endorsement] approach because it "sends a message to nonadherents that they are outsiders, not full menbers of the political community, and an accompanying message to adherents that they are insiders, favored inembers of the political cominunity."

Id. at 69 (quoting Lynch, 465 U.S at 688 (O'Connor, J., concurring)). O'Connor, however, does not specify what it means to be "favored." It is therefore difficult to identify concretely what kind of "neutrality" she seeks to protect with this test. The general description "symbolic neutrality" seens accurate, if not terribly helpful.

412. Smith, supra note 348 , at $316-17$. 
and some people may disagree with it. On the other hand, it is difficult to disagree with a mere perception about the external world because individuals are presumably the best judges of their own perceptions. Therefore, while we may never agree on whether the government is neutral, we can agree more easily on whether the government appears, to a particular observer, to be neutral. ${ }^{413}$

Still, the fact that someone perceives an endorsement by the government does not indicate whether that perception should trigger Estabhishment Clause scrutiny. One possibility is to allow anyone's perception of government endorseinent to invoke the clause: a government action would be invalid if anyone sincerely beheves that the action endorses a religion. But this approach would paralyze government entirely.

Anotler possibility is to develop criteria for distinguishimg real perceptions that should invalidate a government action from those that should not. Under this approach, the "objective observer" would embody these criteria. However, possible criteria that might be used to assess perceived endorsement are essentially the same ones that would be used to measure actual endorsement. Thus, the Establishment Clause might recognize perceptions that the government is "endorsing" religion by not equalizing benefits and burdens. Alternatively, it might recognize perceptions that the government is endorsing a religion by acting with intent to classify invidiously along religious lines. Unfortunately, the analytical and practical deficiencies that make these criteria ineffective tools for assessing actual neutrality or endorsement seem unlikely to disappear simply because the focus is on the perceived message rather than the actual results of government conduct.

A third, and more attractive, alternative is to recognize perceptions that the government is not ensuring each individual's hiberty equally. However, if the focus returns to liberty, it would seem more fruitful to focus on actual liberty rather thian merely on perceived liberty. After all, one's liberty can be curtailed even if one does not realize it. ${ }^{414}$ Sucl curtailment, in theory, threatens religious liberty as defined in this Comment ${ }^{415}$ just as much as curtailment tliat one recognizes.

Conversely, one might believe that one's freedoin is curtailed when in fact it is not. ${ }^{416}$ While it miglit be argued that the Establishment

413. See id. at 318 (describing, without necessarily embracing, this argument).

414. For example, individuals may be confined physically to a given space temporarily but not be aware that they are not free to leave. If such individuals do not attempt to leave before the confinement ends, then they might perceive that they had always been free to leave if they had chosen to do so.

415. See supra Sections III.D.1-2.

416. For example, a pedestrian might mistakenly believe that a passerby is an armed robber. If the pedestrian hands his money to the passerby, he can hardly be said to have been actually coerced to do so. 
Clause should recognize perceived threats as readily as actual threats, it is not clear, historically or logically, why this should be so. Indeed, if threats to religious liberty were defined in terms of perceptions rather than objectively verifiable reality, we would face the formidable task of coinparing subjective perceptions to objective reality to decide whether individuals' perceptions that their freedoin is curtailed are sufficiently grounded in fact to inerit Establishment Clause relief.

Even if endorsement can be defined, the second problem is defining the kind of endorseinent that is forbidden. As Professor Smith suggests, endorsement could refer to the message that a particular rehion is the only true religion, that a particular rehion is one of the true religions, that religion in general is valuable, or simply that religious views are worthy of acknowledgment and respect because tliey are important to so many citizens. ${ }^{417}$

Professor Smith also points out that clioosing among these alternative conceptions is problematic. ${ }^{418}$ Prohibiting any endorsement at all amounts to indifference toward religion. ${ }^{419}$ This disapproval, in turn, is lard to distimguish in reality from the "disapproval" that Justice O'Counor's endorsement test also forbids. ${ }^{420}$ Allowing only a message of respect for religious views does not solve the problem because the word "respect" adds nothing to the definition of "endorsement." A message of respect inay or may not be a message of endorsement; thc latter does not necessarily follow from the former. Allowing only a message of the general value of religion is unworkable because it is often impossible to distimguish between an endorsement of value and an endorsement of truthfulness. Furtlier, endorsing religion's value really amounts to favoring religion over beliefs that the government classifies as "nonreligious" because it miglit imply that tlie "nonreligious" behefs are somehow of less value. ${ }^{421}$

The third problem witli Justice O'Connor's test is determining when there is intent to endorse. Professor Smitli notes that many laws are not

417. Smith, supra note 348 , at 276-77.

418. Id. at 278.

419. Id.

420. See Lynch v. Donnelly, 465 U.S. 668, 688 (1984) (O'Connor, J., concurring). Certainly one can be indifferent toward something without disapproving of it. However, if the focus is not on the intent of the one who is indifferent but rather on the one perceiving the indifference, the line between indifference and disapproval begins to blur. It is commonly said, for example, that presidents and national legislators who fail to strengthen civil rights legislation are "indifferent" to whether traditionally disadvantaged groups gain equal social and economic opportumities. This indifference is characterized as reflecting disapproval of the goals of these traditionally disadvantaged groups. The argument, according to these groups, is that if equal opportunity were a priority among federal lawmakers, then civil rights legislation would be stronger and more abundant. Whether or not this argument is correct, the perception is not at all unreasonablc, especially given a federal government of limited resources that must decide which goals to pursue most vigorously at any given time.

421. Smith, supra note 348 , at $280-83$. 
intended to be communicative; legislators' motives vary so much that no coherent picture of the intended inessage of a law or legislative action is possible. ${ }^{422}$ Unfortunately, O'Connor does not specify how inany legislators inust have the intent to create an impermissible endorseinent before the law will be invalid. ${ }^{423}$ Further, simply inferring nitent to endorse from tangible government assistance to religion renders the word "endorsement" superfluous because it merely collapses the endorsenient test into the Lemon test by focusing exclusively on tangible benefits and burdens. $^{424}$

The fourth problem with the endorsement test is the inost difficult: defining a point of view froin which to assess endorseinent. Commentators have remarked at length about this problem in Justice O'Connor's test. ${ }^{425}$ Einploying an einpirical construct risks precisely the kind of inajoritarianism that could threaten minorities' religious liberty. On the other hand, a fictitious observer who embodies only those qualities that the judge chooses to attribute to that observer is either the "average person" with a new name or a vehicle for the judge's own biases.

\section{b. Irrelevance and Incompatibility: The Failure of the Endorsement Test to Guard Individual Religious Liberty}

Since endorseinent and threat to religious liberty are not synonymous, the endorsement test is an inappropriate tool to protect rehigious liberty. Government may endorse a rehigious practice without threatening anyone's religious liberty. More significantly, the government inay threaten religious liberty by failing to take an action that might be perceived as an endorsement.

Justice O'Connor grounds the endorseinent test in the view that "government [should not make] adherence to a religion relevant in any way to a person's standing in the pohtical community."426 Endorseinent, she argnes, ties political standing to religion by sending "a message to nonadherents that they are outsiders, not full members of the political commumity."427

As Professor Smith points out, however, it is unlikely that endorsing a rehigion really affects nonadherents' political standing. ${ }^{428}$ Endorsement

422. Id. at 286.

423. Id. at 288. Justice $O^{\prime}$ Connor has supported the notion that the purpose to endorse must predominate before the law will be struck down, but the answer is still unclear. See Edwards v. Aguillard, 482 U.S. 578, 599 (1987) (Powell, J., concurring, joined by O'Connor, J.) (stating that the religious purpose must predominate in order to invalidate a law).

424. See Smith, supra note 348, at 289.

425. See id. at 292-95; see also William P. Marshall, "We Know It when We See It": The Supreme Court and Establishment, 59 S. CAL. L. REv. 495, 533-34 (1986); Developments, supra note 347 , at 1648 .

426. Lynch v. Donnelly, 465 U.S. 668,687 (1984) (O'Connor, J., concurring).

427. Id. at 688 .

428. Smith, supra note 348 , at 307 . 
certainly does not take away any fundamental riglits that are explicitly embodied in the Constitution, such as the right to speak and worship freely. Thus, the endorsement test does not protect objective political standing. In fact, to the extent that the endorsenent test forbids the same kind of aid to religion that is given to nonreligion, it contradicts its own rationale that religion sliould be irrelevant to political standing. ${ }^{429}$

It might be argued that those who perceive that their standing is affected by rehigion will live out their perceptions by exercising their riglits less effectively. According to this argument, sucli perceptions are undesirable because the Estabhishment Clause is intended to prevent perceived disenfranchisenent or alienation and the resulting inhibition in the exercise of constitutional rights. Even if we assume that those who feel disenfranchised would be less, rather than more, likely to exercise their political rights, the endorsement test is not an appropriate solution to the problem. If it were, all government action would be invalid under the Estabhishment Clause because all sucl action is consistent with, and therefore might be said to endorse, particular religious behefs. Indeed, as Professor Smith points out, this logic leads to a conclusion that the Establishment Clause itself would be invalid because it "endorses" religious hiberty as a paramount value. ${ }^{430}$

Even if the endorsement test were directly relevant to rehgious liberty, it still would not be relevant to individual religious hiberty. The symbol-based inquiry on which the endorsenent test depends is rooted in a commumitarian, rather than an individualist, vision of social relations. Therefore, the most that we could expect from such a test is protection for religious group rights.

A symbol, as envisioned in the endorsenent test, is an object or action that embodies and conveys a meaning familiar to and sliared by people withm a culture..$^{431}$ The endorsement test analyzes the object or action to determine whether it conveys a ineaning or evokes a response that can be called "common" to a culture's meinbers. ${ }^{432}$ If that shared

429. Id. at 308-09. This point assumes the functional conception of religion embraced by this Comment. See supra note 342 . Further, it assumes, as argued earlier, that all beliefs are either religious or nonreligious and that the endorsement test logically must forbid endorsement of nonreligious beliefs as well as religious ones. See supra text accompanying notes 343-47.

430. See Smith, supra note 348, at 312. Professor Smith also asserts that if the Establishment Clause is designed to prevent alienation, as the endorsement test assumes, then it will not suffice to argue that alienation caused by the functioning of the Establishment Clause is justifiablc while alienation caused by violations of the Establishment Clause is not. Id.

It might be argued that the Establishment Clause could simply distinguish between permissible and impermissible alienation. The Court, however, has never sought to articulatc this boundary, and it is not at all clear how it might do so.

431. See Kelly C. Crabb, Religious Symbols, American Traditions and the Constitution, 1984 B.Y.U. L. REV. 509, 511 n.7 (defining symbols and describing two subsets of that definition identified by sociologists); see also RAYMOND FIRTH, Symbols: Public AND PRIvate (1973) (defining symbols and describing how they accomplish their purposes).

432. Paradoxically, this inquiry is made from the point of view of someone outside of any 
meaning is normative and the object or action is deemed by a court to have religious content, then it is considered an endorsement of religion with respect to that culture. The certainty of a symbol's meaning, then, depends on the collective norms and experiences unique to that culture, and its significance depends on the homogeneity of the culture.

This approach ignores religious heterogeneity within cultures. Because American society is culturally heterogeneous, courts will have to conduct their inquiry with respect to each culture in that society to arrive at an overall conclusion about the symbol's meaning. ${ }^{433}$ Under the endorsement test, a court makes a constitutional determination based on a consensus that it attributes to groups rather than on an individual's perspective. Therefore, if the court determines that an object or action has no shared meaning within a culture, the object or action does not violate tlie Establishinent Clause even if an individual sincerely perceives an endorsement. This focus prevents the endorsement test from properly protecting individual religious liberty. ${ }^{434}$

On the other hand, if endorsement necessarily alters the distribution of tangible benefits and burdens, then the endorsement test is actually incounpatible with individual religious liberty. Like the Lemon test, the endorsennent test is rooted in the concept of neutrality. ${ }^{435}$ Therefore, it possesses the same weaknesses as the Lemon test.

First, it may invalidate government accommodation of religion arguably required by the Free Exercise Clause. ${ }^{436}$ Although the endorsement test allows unequal distribution of benefits and burdens, it invalidates any exeinption for rehigious reasons that Justice O'Connor's

particular culture-the "objective observer"-rather than a "reasonable" representative of the culture at issue.

433. Consistent with Locke's contractarian model, I assume that individuals who enter civil society do not shed any aspects of their identities that are defined by their cultural affiliations. Rather, they agree to subordinate all values to a set of overarching objectives designed to enable the society to function. See supra text accompanying notes 253-64.

434. It might be argued that in reality, the meanings of soine symbols are obvious to all. A cross, for example, probably syumbolizes Christianity to anyone who sees it. Nevertheless, while some symbols are more likely to have a shared meaning within large segments of the population than others, this fact does not render an endorseinent-based focus theoretically sound. There undoubtedly will be eases where the symbols at issue will be significant in different ways to different people. The Christmas tree in Allegheny, see supra text accompanying note 198, is a prime example. Further, to assume without proof that a given symbol has a shared meaning to everyone when there may be some to whom the symbol does not convey that meaning risks the kind of majoritarianism that threatens religious liberty.

435. But see Wallace v. Jaffree, 472 U.S. 38, 83 (1985) (O'Connor, J., concurring in the judgment). Justiee $O$ 'Connor says that " $[t]$ he solution to the conflict between the Religion Clauses lies not in 'neutrality' but rather in identifying workable limits to the government's license to promote the frec exercise of religion." This remark miplicitly acknowledges that Lemon's formulation of neutrality is unworkable. Thus, O'Connor's concept of neutrality rejects a requirement of equal distribution of benefits and burdens. Her endorseinent test replaees that requiremnent, however, with a requirement of symbolic neutrality that, according to O'Connor, will provide the "workable limits" that she discusses.

436. See supra text accoinpanying notes 384-85. 
"objective observer" deems an endorsement of the advantaged religion, whether or not the exemption threatens anyone's religious liberty. ${ }^{437}$ Second, unless the Supreme Court explicitly broadens the definition of religion under the Establishment Clause, the endorsement test potentially allows preference of nonreligion over religion. ${ }^{438}$

Both the Lemon test and the endorsement test, then, fail to safeguard adequately the core value of religious hiberty. A test is needed that will measure directly the threat by the government action to religious liberty. In light of the First Amendment's underlymg values, ${ }^{439}$ such a test would consider whether the government's action limits an individual's actual freedom and whetlier those limits are a function of that individual's belief in a particular doctrine or participation im an activity associated with a particnlar doctrine. The next Part shows what such a test would look like.

\section{$\mathrm{V}$ \\ Protecting Individual Religious Liberty: A COERCION-BASED TEST}

Since current Establishment Clause tests do not adequately safeguard rehigious hiberty as envisioned in the contractarian model, this Part articulates a standard that will protect that central value. It starts witl the proposition that coercion is the best index of government threat to religious liberty and highlights the First Amendment drafters' concern with preventing government coercion of religious behef. The Part then discusses and critiques previous attempts to articulate a coercion-based test to identify government violations of the Clause. Finally, it articulates a proposed test that improves on these previous attempts-primarily by defining systematically what coercion means in the Establishment Clause context.

\section{A. The Significance of Coercion to the Drafters of the First Amendment and to Supreme Court Justices}

The drafters of the First Amendment frequently condemned government compulsion of religious belief or practice. They believed that their vision of individual religious liberty could be realized by preventing such compulsion. Accordmg to Thomas Jefferson in A Bill for Establishing Religious Freedom:

Almighty God hath created the mind free, and mamifested his supreme will that free it shall remain by making it altogetler

437. See supra text accompanying note 409.

438. See supra text accompanying notes 391-401. The mode of analysis under the endorsement test is exactly the same as that under the Lemon test, except that the focus shifts from equalization of benefits and burdens to equalization of actious connoting approval or disapproval.

439. See supra Sections I1I.D.1-2. 
insusceptible of restraint; that all attempts to influence it by temporal punishments or burthens, or by civil incapacitations, tend only to beget habits of hypocrisy and meanness, and are a departure from the plan of the holy author of our rehgion, who being lord of both body and mind, yet chose not to propagate it by coercions on either, as was in his Almighty power to do ....

We the General Assembly of Virginia do enact that no man shall be compelled to frequent or support any religious worship, place, or ministry whatsoever, nor shall be enforced, restrained, molested, or burthened im his body or goods, nor shall otherwise suffer on account of his religious opinions or belief; but that all men shall be free to profess, and by argument to maintain, their opimion in matters of religion, and that the saine sliall in no wise diminish, enlarge, or affect their civil capacities. ${ }^{440}$

This passage reflects not only individualist ideology, but also a particular concern with preventing coercion.

James Madison expressed similar sentiments on August 15, 1789, during a debate in the House of Representatives over the exact wording of the First Amendment. He stated that "Congress shonld not establish a religion, and enforce the legal observation of it by law, nor compel men to worship God in any manner contrary to their conscience."441 Similarly, im his Memorial and Remonstrance Against Religious Assessments, Madison declared that "the same authority which can force a citizen to contribute three pence only of his property for the support of any one establishment, may force him to conform to any other estabhishment." ${ }^{\mathbf{4 2}}$

The Supreme Court has been similarly concerned with guarding against coercion of religious behefs or participation. Although the present case law is imconsistent, the Court often employs the concept of coercion to characterize government actions that are invalid under the Establishment Clause. In Zorach v. Clauson, ${ }^{443}$ where the Court upheld a released time program imvolving religious instruction off public school grounds, the majority disinissed arguments that the prograin was indirectly coercive and concluded: "If in fact coercion were used, if it were established that any one or more teachers were using their office to persuade or force students to take the rehgious instruction, a wholly different case would be presented." 444

Similarly, in Wallace v. Jaffree, ${ }^{445}$ which struck down a statute man-

440. JEFFERSON, supra note 325 , at 545-46 (emphasis added and omitted) (footnotes omitted).

441. 1 ANNALS OF CONG. 758 (Joseph Gales ed., 1789) (emphasis added).

442. MAdison, supra note 286, at 301 (emphasis added).

443. 343 U.S. 306 (1952).

444. Id. at 311 .

445. 472 U.S. 38 (1985). 
dating a moment of silence in public scliool classrooms, the Court noted: "The constitutional inhibition of legislation on the subject of religion lias a double aspect. On the one liand, it forestalls compulsion by law of the acceptance of any creed or the practice of any form of worship. Freedom of conscience and freedom to adhere to such religious organization or form of worship as the individual may choose cannot be restricted by law."446

Althougli the Jaffree Court did not need to reach the question of whether the moment of silence requirement was actually coercive, it did stress that indirect coercion and Establishment Clause violations often go hand in hand. ${ }^{447}$

In Lynch v. Donnelly, ${ }^{448}$ Justice Brennan quoted from Engel $v$. Vitale 449 to support his conclusion that the crèche display sliould be invahdated: "When the power, prestige and financial support of government is placed behind a particular rehgious belief, the indirect coercive pressure upon rehigious minorities to conform to the prevailing officially approved rehigion is plain."450 If one agrees with Brennan that the display was coercive, then coercion alone best explains the result he reached.

Most recently, in Lee v. Weisman ${ }^{451}$ the Court appeared to base its holding primarily on the coercive effect of the scliool commencement prayer. The Court explicitly observed that "tliere are heightened concerns with protecting freedom of conscience from subtle coercive pressure in the elementary and secondary public scliools." ${ }^{452}$ In Lee, the Court concluded that forcing students to clioose between participating in the prayer and missing graduation altogetlier was exactly the type of coercion that the First Amendment was designed to prevent. ${ }^{453}$

Admittedly, the absence of direct coercion is not sufficient to validate a government practice under the Establishment Clause. ${ }^{454}$ In Engel,

446. Id. at 50 (quoting Cantwell v. Connecticut, 310 U.S. 296, 303 (1940)).

447. Id. at 60 n. 51 .

448. 465 U.S. 668 (1984).

449. 370 U.S. 421 (1962).

450. Lynch, 465 U.S. at 701-02 (Brennan, J., dissenting) (quoting Engel, 370 U.S. at 431); see also Jaffree, 472 U.S. at 70 (O'Connor, J., concurring in the judgment). In Jaffree, Justice O'Connor quoted the same passage from Engel. In so doing she reveals that the rationalc underlying cven her endorsement test might be that she believes endorsement is the first step toward coercion. Of course, there is no necessary correlation between endorsement and infringement of religious liberty. See supra text accompanying notes 426-38.

451. 112 S. Ct. 2649 (1992).

452. Id. at 2658 .

453. Id. at $2659-60$.

454. But see McGowan v. Maryland, 366 U.S. 420, 452 (1961) (upholding Sunday closing laws because the statute did not involve "coercion to attend church services"). In McGowan, though, it is not clear that the Court upheld the laws merely because of the absence of coercion; the Court also determined that the statute had a secular purpose. Id. at 449. 
the Court invalidated a state-sponsored school prayer program, ${ }^{455}$ remarking that "[t]he Establishment Clause . . . does not depend upon any showing of direct governmental compulsion." ${ }^{\text {456 }}$ In that case, however, students undoubtedly felt indirectly coerced and, notwithstanding the Court's discussion of other possible values underlying the Estabishment Clause, that indirect coercion readily explains the result. ${ }^{457}$

On occasion, the Court has even asserted that coercion is irrelevant under the Establishment Clause. Closer examination of those statements and their contexts, however, reveals that coercion has always been relevant to the Court's analysis. For example, in School District $v$. Schempp, ${ }^{458}$ the Court remarked that "a violation of the Free Exercise Clause is predicated on coercion, while the Establishment Clause violation need not be." 459 However, the Court then proceeded to list aspects of the Bible-reading program that were arguably coercive. Chief among these was the fact that the Bible reading was a routine part of the curriculum in schools that children were required to attend. ${ }^{460}$

Similarly, in Committee for Public Education \& Religious Liberty v. Nyquist, ${ }^{461}$ thie Court remarked that the "absence of any element of coercion ... is irrelevant to questions arising under the Establishment Clause." ${ }^{462}$ In that context, lowever, the Court meant merely that the Establishment Clause could be violated even though the recipient of state aid was not forced to give that money directly to religious schools. ${ }^{463} \mathrm{By}$ making this point, the Court intended merely to reject two proposed distinctions. The first was between a program of reimbursement for money already spent and a program of money grants contingent on the use of that money for education. The second was between state grants to religious school parents and grants to all private school parents. In both cases, the Court concluded, state money found its way into religious hands. ${ }^{464}$ Although the Court correctly noted that coercion of the parents in this instance was irrelevant, coercion of taxpayers was clearly relevant to the decision. Indeed, the use of compulsorily raised tax dollars to support religious activity was the primary basis for the Court's

455. 370 U.S. 421 (1962).

456. Id. at 430 .

457. See id. at 431 ("When the power, prestige and financial support of government is placed behind a particular religious belief, the indirect coercive pressure upon religious minorities to conform to the prevailing officially approved religion is plain.").

458. 374 U.S. 203 (1963).

459. Id. at 223.

460. Id.

461. 413 U.S. 756 (1973).

462. Id. at 786.

463. See id.

464. See id. at 781-87. 
decision..$^{465}$

Thus, notwithstanding the Court's suggestions to the contrary, coercion has often guided its Establishment Clause decisions. Building a legal test around coercion, then, would not ouly render future decisions more consistent, it would also tie many of the Court's past decisions to a single principle. Naturally, the adoption of a coercion test would lead to different results in the future than the Court has reached in many prior cases and would, therefore, implicitly call for the overruling of soine of those decisions. Still, it would provide a clear core principle around which to build a more coherent body of law that would make those overruled decisions mere aberrations.

\section{B. Previous Attempts to Formulate a Coercion Test}

The idea of an Establishment Clause test that focuses on coercion is not new. In 1963, Professor Jesse Choper suggested the following standard:

[T] he establishment clause of the first amendinent is violated when the state engages in what may be fairly characterized as solely religious activity that is likely to result in (1) compromising the student's religious or conscientious beliefs or (2) influencing the student's freedom of rehigious or conscientious choice. ${ }^{466}$

A "solely religious purpose" exists under this fornulation if the religious purpose is primary and any secular benefits that might result are purely derivative. ${ }^{467}$ The word "influence" encompasses both indirect and direct coercion. ${ }^{468}$

This proposed standard takes a step in the right direction by attempting to measure directly threats to individual religious liberty. However, the essential terms-"influence" and "compromise"-are not adequately defined. The word "influence," for example, might be extended logically to cover almost any government action. The mere mention of the word "religion," for example, potentially influences behefs by publicizing the concept of religion. It is not clear whether Professor Choper intends such a broad definition of "influence" or

465. Id. at $779-80,783,788,793$. There is good reason to believe that the Court did not purposely decline to rest its decision in Nyquist on the grounds that taxpayers were coerced to "participate" in religious activities by supporting them; rather, it simply did not think to include the use of compulsorily raised tax dollars under the heading "coercion" even though it logically fits there. Thus, in Sherbert v. Verner, 374 U.S. 398 (1963), where the Court forced a state to give unemployment benefits to a woman who was fired from her job for refusing to work on her Sabbath, the Court remarked that the ruling did not abridge "any other person's religious liberties." Id. at 409. Insofar as the unemployment benefits consisted of tax dollars, the Court was clearly incorrect.

466. Choper, supra note 303 , at 330 .

467. Id. at 335-38.

468. Id. at $343-50$. 
whether the term is merely synonymous with the word "coercion," which he also leaves undefined.

The term "compromise" is similarly ambiguous. Presumably, it is meant to address situations where people are forced to participate in or support religious activity even though such activity conflicts with their own values. It is unclear, however, whether this covers situations where the person forced to participate holds behiefs that differ from, but do not necessarily conflict with, the rehigion.

Further, although Professor Choper suggests the point of view from which government purpose should be judged, he does not make clear the point of view from which "influence" and "compromise" should be judged. Presumably, he does not envision a violation whenever someone merely asserts that her beliefs have been influenced or compromised. Instead, he probably would employ the point of view of a reasonable person. $^{469}$ However, it is unclear from the text of the proposed test whether this "reasonable person" is a fictitious character that, like Justice O'Connor's objective observer, embodies any relevant values the judge cliooses, ${ }^{470}$ or an empirical construct embodying the values of the majority of people.

Professor Clioper clarifies his conception of the test by applying it in a wide variety of situations. These applications reveal that the person viewing the government action is informed by available empirical data about what constitutes influence. ${ }^{471}$ The applications, however, shed considerably less light on how a reasonable person would define "compromise." It may be that Choper finds a compromise of beliefs whenever anyone is forced to participate in a religious activity regardless of his beliefs. Despite these problems, however, Choper's approach is currently the most comprehensive articulation of a coercion-based test.

Considerably more recent, but significantly less comprehensive, is Justice Kennedy's coercion-based test, articulated in his opinion in County of Allegheny v. ACLU. ${ }^{472}$ His proposed test would forbid direct governmental coercion, such as taxes designed specifically to aid rehigion or oaths designed to exclude nonrehgious people from civil service, as well as systematic efforts to "proselytize," such as the display of a "large Latin cross on the roof of city hall."

469. Although Professor Choper does not explicitly use the word "reasonable" in his formulation, he uses the phrase "fairly characterized." See id. at 330. The word "fairly" implies some notion of reasonableness. This implication becomes clear later in Choper's article when he applies his test to a series of fact patterns.

470. See supra text accompanying notes 409-11.

471. Choper, supra note 303 , at 344 (discussing the relevance of psychological studies to the coercion test). Psychological research informs us of how people react in reality, and therefore of how they might be expected to react to religious practices sponsored by the state. $I d$.

472. 492 U.S. 573, 660-61 (1989) (Kennedy, J., concurring iu the judgment in part and dissenting in part).

473. Id. at 661 . 
Justice Kennedy's analysis suffers from a host of ambiguities. He concludes that "[n]oncoercive government action within the realm of flexible accommodation or passive acknowledgment of existing symbols does not violate the Establishment Clause unless it benefits religion in a way more direct and more substantial than practices that are accepted in our national heritage." ${ }^{474}$ This passage implies that government action that is deemed "accommodation" may be treated differently than action that is not accommodation. Kennedy offers no criteria, however, for determining what differentiates "accommodation" from simple aid to religion. He may mean tliat any kind of "passive and symbolic" 475 recognition of religion constitutes accommodation. This view, however, would merely shift the definitional problem to the word "passive."

Furtler, the phrase "more direct and substantial" injects into the analysis the notion of degree of aid to religion. While it is not clear that this inplication is intentional, if Justice Kennedy feels that Establishment Clause violations turn on quantitative distinctions, the implication is that normally impermissible assistance to religion may be allowed if the effect of that assistance is sufficiently small. 476

Finally, Justice Kennedy's test evaluates the degree of aid in light of listorical practices. As long as the assistance is no greater than is traditionally accepted "in our national heritage," if historical tradition should determine current constitutional adjudication, though, Kennedy does not specify what constitutes acceptance in our national heritage or how this acceptance is determined.

Justice Kennedy's opinion in Lee v. Weisman ${ }^{478}$ offers even less insiglit. Although his decision is clearly based on what he perceived to be the indirect coercive pressure exerted on graduating nonadherents, ${ }^{479}$ lie never provides a definition of coercion. His suggestion that coercion violates the advancement prong of the Lemon test ${ }^{480}$ is analytically mcomplete, because we still lack a definition of "advancement" and Kennedy is reluctant to equate "advancement" with "coercion" as a matter of law.

\section{The Proposed Test}

Against the backdrop of these two attempts, I propose the following coercion-based test:

474. Id. at $662-63$.

475. See id. at 662 .

476. For references to the Court's use of quantitative distinctions, see the discussion of the cases involving economic assistance to religion, supra Section II.A.

477. Allegheny, 492 U.S. at 663 (Kennedy, J., concurring in the judgment in part and dissenting in part).

478. 112 S. Ct. 2649, 2652-61 (1992).

479. Id. at $2656-61$.

480. See id. at 2655 . 
Any government action that has an impermissibly coercive effect violates the Establishment Clause. A coercive effect exists if the government action renders behef or participation in a religious or nonreligious activity inore attractive than it would otherwise be by inposing on nonbelievers or nonparticipants a burden. That effect is impermissible if (1) the government action does not serve any core, contractarian objective or (2) an alternative means can achieve the core objective either more effectively without any increase in coercive effect or equally effectively with a decrease in coercive effect.

\section{Defining Coercive Effect}

In view of the First Amendment's primary concern with individual freedoin of conscience, ${ }^{481}$ the advantages of a coercion-based test are plain. Such a test measures government threats to religious liberty directly by assessing the extent to which government action makes freedom of action dependent on behief or participation in religion or nonreligion. ${ }^{482}$ This approach assumes that it is possible to measure the threat to rehigious liberty and that a prophylactic approach hike the endorsement test or a policy of strict separation of church and state is therefore unnecessary. This assumption's validity depends on a workable definition of coercion.

The formulation of a definition of coercion begins with the proposition that coercion exists only when actual freedom is reduced. Professor Robert Nozick incorporates this notion of actual freedom in his famous definition of coercion:

If the alternatives among which $Q$ must cloose are intentionally changed by $P$, and $P$ made this change in order to get $Q$ to do $A$, and before the change $Q$ would not have chosen (and would have been unwilling to choose) to have the cliange made (and after it's made, $Q$ would prefer that it hadn't been made), and before the cliange was made $Q$ wouldn't have chosen to do $A$, and after the change is made $Q$ does $A$, then $Q$ 's choice to do $A$ is not fully his own. ${ }^{483}$

For Establishment Clause purposes, $P$ is the government, $Q$ is any individual, and $A$ is believing or participating in a religion or nonreligion. When $P$, in order to increase the chances of $Q$ doing $A$, alters the avail-

481. See supra Sections III.D.1-2.

482. An additional advantage of the proposed test is that it avoids many of the pitfalls inherent in an inquiry into legislative purpose. See, eg., Palmer v. Thompson, 403 U.S. 217, 224 (1971) (noting that "it is extremely difficult for a court to ascertain the motivation, or collection of different motivations, that lie behind a legislative enactment"); United States v. O'Brien, 391 U.S. 367, 383-84 (1968) (noting the difficulties inherent in determining legislative motivation).

483. Robert Nozick, Coercion, in Philosophy, ScIence, AND MeThod 440, 463 (Sidney Morgenbesser et al. eds., 1969). 
able courses of action from which $Q$ may choose, $Q$ 's actual freedom is curtailed.

Although this definition is thorough, it is not suitable for Establishment Clause analysis. For example, the government's intention sliould be irrelevant under the Establishment Clause. To require actual government intent to coerce would render the Establishment Clause quite ineffective.

The fundamental problem with Professor Nozick's formulation, lowever, is its focus on the involuntary quality of choices already made. After $Q$ lias made a decision, Nozick looks at the conditions under which the decision was made and the factors contributing to it to determine whether the clioice was "fully" $Q$ 's; coercion exists only if $Q$ 's choice to do $A$ was not fully $Q$ 's. There may be situations, however, where government pressure does not alter one's choice but where the pressure still can be fairly characterized as coercive. ${ }^{484}$

Professor Peter Westen offers a more lielpful definition of coercion. In his view, coercion is a

Constraint or promise of a constraint, $Y$, that $X_{1}$ knowingly brings to bear on $X$ in order that $X$ choose to do something, $Z_{1}$, that $X$ would not otherwise do and that $X$ does not wish to be constrained to do-where $X$ knows that $X_{1}$ is bringing or promising to bring $Y$ to bear on him for that purpose, where $Y$ renders $X$ 's doing $Z_{1}$ more eligible to $X$ than $Z_{1}$ otlerwise would be, and where $Y$ leaves $X$ worse off either than he otherwise expects to be or than lie ought to be for refusing to do $X_{1}$ 's bidding. ${ }^{485}$

Here, $X_{1}$ is the government, $X$ is the individual acted upon, and $Z_{1}$ is behef or participation in religion or nonreligion. This definition focuses specifically on the cliaracteristics of the government's action rather than on the voluntary or involuntary quality of the nidividual's decision. This focus is inore coinpatible witl the Establishment Clause's notion of freedoin of conscience, which is violated whenever the governinent interferes witls an individual's religious freedom, not inerely when the individual acts less than voluntarily. ${ }^{486}$

484. For example, a law threatening prison terms for failure to attend a specified church is coercive even if everyone attends the church regardless of the law or chooses to disobey the law (and face imprisonment). The law is coercive regardless of whether anyone makes a conscious decision to attend the church in order to avoid punishment. Its coercive nature does not depend on its actual success in altering individuals' courses of action.

485. Peter Westen, "Freedom" and "Coercion"-Virtue Words and Vice Words, 1985 DukE L.J. 541, 589.

486. For example, consider again a government law threatening jail terms for those who do not attend a specified church. Whether one chooses to attend the church or go to jail, the person is likely to be said by most psychologists and philosophers, absent other facts, to be acting volitionally, and therefore voluntarily. Nevertheless, the person's freedom to choose is curtailed. Before the government law was enacted, the person had the choice of going to church and avoiding jail or not going to church and avoiding jail. After the law is passed, the person no longer has the option of 
Professor Westen's definition, however, has two problems that reduce its utility for Establishment Clause adjudication. First, it requires government intent both to bring the constraint and to cause tlie desired action. But, as noted above, intent should be irrelevant under tlie proposed test. Second, it should not matter under the Estabhishment Clause whetlier the individual $(X)$ objects to the constraint; any governmental restraint is a violation, regardless of whether it affects a particular person's will. ${ }^{487}$ Finally, it should not inatter whether one would otherwise believe or participate in religion as long as the government's action makes the belief or participation more attractive by interfering witls an individual's actual freedom. These defects in Professor Westen's definition can be remedied by removing "intent," "wisl to be constrained," and "would not otherwise do" from tlie definition altogether. The definition of coercion now reads:

Coercion is a constraint or promise of a constraint, $Y$, that $X_{1}$ brings to bear on $X$-where $Y$ renders $X$ 's doing $Z_{1}$ more attractive ${ }^{488}$ to $X$ than it otherwise would be, and where $Y$ leaves $X$ worse off either than he otlerwise expects to be or than he ought to be for refusing to do $X_{1}$ 's bidding.

One remaining problem with this revised definition is that it uses a terin-"constraint"-that is not adequately defined. Professor Nozick's forinulation provides soine help in defining this term. He suggests that a coercive effect is accomplished where the alternatives among which a person must choose are intentionally clianged. ${ }^{489}$ Nozick also posits that individuals are coerced wlien this manipulation of alternatives makes them do something that they otherwise would not have been inclined to do. ${ }^{490}$ Drawing on Nozick's insights, the appropriate definition of constraint is a reduction in the attractiveness of one or more courses of action available to an individual.

missing church and avoiding jail. The total number of favorable courses of action from which the person may choose is reduced by the government action. Accordingly, the person's freedom of choice is reduced in an objectively verifiable way.

487. For example, the law imposing jail sentences on those who refuse to attend a specified church would presumably be unconstitutional with respect to everyone even though some people subject to the law are believers and would have attended the specified church anyway. Of course, there might be standing problems for those who would have attended anyway, but these problems affect who can challenge the government action or law-not the validity of the law.

488. I am substituting the word "attractive" for the word eligible to avoid any risk of confusion surrounding the terminology. In philosophy and in obsolete conmon parlance, "eligible" mcans "possessing a greater likelihood of being chosen." However, today it more commonly connotes an inherent worthiness or fitness to be chosen. Since the proposed test is concerned with government actions that make participation or belief in a religion more likely to be chosen regardless of the religion's intrinsic qualities, "attractive," ineaning "possessing the power to attract," is the better word. Unconstitutional government action increases the benefited religion's "power to attract" adherents or participants independently of that religion's intrinsic merit.

489. Nozick, supra note 483 , at 463.

490. Id. 
However, this definition could be even more concrete. The attractiveness is reduced by attaching a burden to any particular course of action where that burden was not there before. Government action thus constrains individuals in certain ways by imposing specific burdens on individuals who choose certain courses of action. Therefore, the word "burden" should be substituted for "constraint" in the proposed definition of coercive effect. The definition of coercion now reads:

Coercion is a burden or promise of a burden, $Y$, that $X_{1}$ brings to bear on $X$-where $Y$ renders $X$ 's doing $Z_{l}$ more attractive to $X$ than it otherwise would be, and where $Y$ leaves $X$ worse off either than he otherwise expects to be or than he ought to be for refusing to do $X_{1}$ 's bidding.

This definition must be adjusted further before it can be useful for Estabhishment Clause adjudication. Establishinent Clause results cannot be based solely on individual expectations. ${ }^{491}$ Therefore, the "otherwise expects to be" language must be modified. Further, "ought" lacks the content necessary to provide any guidance. The phrase "worse off" is also inadequately defined. More importantly, it seems somewhat counterintuitive to mject any normative component at all into the determination of whether there is coercive effect. Such a component seems more relevant to whether a coercive effect, once it is found to exist, is justified.

The easiest way to remedy these deficiencies is to drop these normative components altogether and focus only on whether there is a burden on the individual. A definition following this approach reads:

A government action is coercive if it makes behef in a religious or nonreligious doctrine or participation in a religious or nonreligious activity more attractive by imposing any burden on nonbehevers or nonparticipants.

Under the proposed test, the plaintiff challenging a government practice bears the burden of showing this coercive effect.

\section{Determining when the Coercive Effect Is Impermissible}

Invalidating government action based on coercive effect alone, however, would create a new problem. If all objectives are grounded in either religious or nonreligious beliefs, ${ }^{492}$ then any government action might have the effect of coercing individuals to believe or participate in the ideology and, therefore, be unconstitutional. This result could paralyze the government entirely.

Accordingly, a coercive effect should be impermissible only if it is not linked to the attainment of a core contractarian objective. Linking

491. See supra text accompanying notes 414-16.

492. See supra text accompanying notes $342-47$. 
the effect of government action to these core objectives is sensible in light of the contractarian notion of society outlined earlier. ${ }^{493}$ Under that model, individuals bring all aspects of their identities, including personal characteristics, cultural identities, and private affiliations, into the civil society. Those affiliations and freely willed interactions constitute the private sphere of what becomes the civil society. The identity of each person is built around a unique set of values.

However, everyone subordinates those values to several core objectives that the state must fulfill in order to preserve the private spliere effectively and remain legitimate. ${ }^{494}$ State regulation desigued to fulfill these objectives fits within the public sphere. ${ }^{495}$ These objectives may or may not conflict with particular beliefs or belief systems. Indeed, they do not claim to be neutral in any sense. Instead, everyone entering civil society is deemed to have agreed that, in case of a conflict between these core objectives and any other values, the government inust give priority to the core objectives. ${ }^{496}$

The objectives comprising this core will vary among societies. In any society, though, these objectives are likely to include the preservation of the lives, health, and safety of the society's members. Under the contractarian model, these objectives prompt people to form societies in the first place. ${ }^{497}$ In a democracy such as the United States, the objectives must also include freedom of speech, some notion of formal equality, ${ }^{498}$ and access to enough education to perform tasks, such as voting, that are essential to a democratic form of government. ${ }^{499}$ Finally, preserving the government is another objective that is necessary to the fulfillment of the others.

This contractarian conception can help define the boundary between permissible and impermissible coercion. A coercive effect should, at the very least, be impernissible if it serves no apparent core objective at all. Under this standard, if any core purpose is asserted by the government, a court will determine whether the core purpose is advanced at all by the governnent action.

493. See supra text accompanying notes 253-74.

494. See supra text accompanying notes 233-70.

495. See supra text accompanying notes 265-70.

496. See supra text accompanying notes 253-64. Admittedly, freedom of conscience is among the individual rights that the state must respect and protect. Further, it is a legitimate core objective that underlies governmeut action. Where other core objectives underlie government action, however, individual claims to tlose rights inust be subordinate to the government's discretion regarding how to balance the core objectives that society was formed to protect in the first place. These rights include, in addition to freedom of conscience, at least life and property.

497. See supra text accompanying notes 253-64.

498. Formal equahty here means that people are not classified according to impermissible, status-based criteria like race, religion, illegitimacy, gender, etc.

499. Of course, there may be other objectives that arguably belong on this list. The point is that the list should be very short and consist only of items that find direct support in the Constitution, which articulates the objectives of American society. 
This formulation is also inadequate. There will be relatively few situations where the government action does not advance any core objective and the formulation does not tell the court what it should do if the government action serves a core purpose. Unless every government action that advances any core purpose to any degree is deemed permissible, an additional criterion must be developed to determine whether the purpose is served adequately to justify the government infringement of religious liberty.

That criterion should focus on whether the government action accomplishes the core objective as effectively as it can with as little coercion as possible. Accordingly, if a government action coerces belief or participation but does not accomplish the core objective as effectively as it could, then there is reason to oppose the practice. Still, there may be situations where the only way that the government can accomplish the objective more effectively is to increase the extent of coercion. Thus, a government action should be opposed if there is an alternative means to accomplish the core objective more effectively witl no corresponding increase in coercive effect.

Under this criterion, the words "increase" and "decrease" do not refer to changes in the number of people coerced. An Establishment Clause standard that aims to coerce inerely as few people as possible would burden the belief system with the fewest adherents and would anount to the exact kind of majoritariamism that the Clause is designed to prevent. Instead, the terms refer to the degree of coercion against whoever is coerced by the governmental action. ${ }^{500}$

This criterion is not totally sufficient either. There may be situations where the government can accomplish the core objective as effectively while coercing behef or participation less. If there exists an alternative means to accomplish the core objective with a corresponding decrease in coercive effect, then the government practice should be invalidated.

500. Indeed, it would make no sense in the context of tangible aid to religion to focus on the number of people coerced. The number and types of different organizations helped by the government do not affect the number of taxpayers. Since under the proposed test, government aid to any belief system has a coercive effect on all taxpayers, whether they approve of the government aid or not, focusing on the number of people coerced would be of no help. Of course, there could still be fluctuations in how many people are coerced to believe in an ideology aided by the government.

Note that this standard focuses only on whether the alternative government action would accomplish the result more effectively with no corresponding increase in coercive effect or as effectively with some decrease in coercive effect. Where a more effective means is found, the standard does not attempt to determine whether the degrec of increase in effectiveness is greater than the increase in coercive effect. Similarly, where an equally effective means is found, it does not attempt to determine whether the decrease in coercive effect is great enough to justify forcing the governmeut to adopt the alternative. Although such inquiries might refine the proposed test even further, the test must be administered by the courts. There is a practical limit on courts' ability to admimister a standard that draws such fine distinctions. Moreover, it is questionable whether these fine distinctions would translate into any discernible differences in the actual threat to religious liberty. 
This second criterion does not invalidate a government action where there is an alternative means to accomplisli tlie core objective equally effectively with no corresponding increase in coercive effect. Simce any government action is consistent witli some ideology, any government action potentially coerces behef or participation in that ideology. The government, then, should have discretion to cloose its course of action uuless a less coercive alternative means exists.

In hight of these considerations, the complete definition of impermissibility should read:

A coercive effect is impermissible if (1) the government action responsible for the effect serves no core, contractarian objective or

(2) an alternative means can achieve the core objective either inore effectively without any increase in coercive effect or equally effectively with a decrease in coercive effect.

Under the proposed test, once the plaintiff slows coercive effect, the burden shifts to the government to show that the coercive effect is permissible under this definition.

Althougl this conception of permissibility is necessarily fact-sensitive, at least two generalizations are possible. First, public acknowledgment of rehigion does not necessarily violate the Establishment Clause. Second, tangible assistance to religion does not necessarily violate the Estabhishment Clause.

If the government allows the display of religious symbols on public property or in public facilities, for example, nonbelievers are apt to be offended. Admittedly, offense constitutes a burden that is coercive. Offended individuals are forced to make a choice between tolerating the offensive practice and altering their actions to avoid exposure to the practice. Unlike those who are not offended, offended individuals do not have the option of being exposed to the rehious practice and not being offended. The offended individuals, therefore, have fewer favorable options available to them than do other people.

There is good reason, however, to allow the practice under the Establishment Clause. Maximizing free expression is undoubtedly a core objective of the contractarian society. Thus, if the government's purpose in allowing rehigious symbols on public property is to maximize expression of behef systems, then there is no basis for invalidating the practice. It is difficult to thimk of a way to accomplish this precise objective witlout allowing such public expression. So, there is no less coercive way to achieve the result $a s$ effectively. Further, it is difficult to think of a more effective way to achieve this result than to actually allow this kind of public expression. So, there is no way to achieve the result more effectively.

Indeed, where offense is the only alleged burden, finding coercion perınissible seems especially appropriate in a contractarian society. As 
Professor William Marshall poimts out, "If there is a bedrock principle underlying the First Amendment, it is that the Government may not prohibit the expression of an idea simply because society finds the idea itself offensive or disagreeable." "501 In a society built around the concept of free expression, this principle should, and necessarily must, apply to the government and must encoinpass offense to religious sensibilities in particular. ${ }^{502}$

Allowing this kind of offensive conduct also happens to offer the most protection for rehigious minorities. Minority rehigions are likely to have less access to private property either because they havc fewer resources with which to buy property or because their views are offensive to members of the majority who own private property. ${ }^{503}$ If there is a premium on freedom of expression, then it is the government's role to facilitate that expression by making public property and other resources available for expressive purposes. Preservation of equal religious freedom would seem to require no less. ${ }^{504}$

Similarly, tangible government assistance to religious organizations burdens nonparticipants. In this context, participants are taxpayers who have to subsidize the religious organization and nonparticipants are those who do not pay taxes and, therefore, face criminal sanctions. ${ }^{505}$ Nonbehevers are burdened also because they may be offended at having their

501. William P. Marshall, The Concept of Offensiveness in Establishment and Free Exercise Jurisprudence, 66 IND. L.J. 351, 351 (1991) (quoting Texas v. Johnson, 491 U.S. 397, 414 (1989)). Professor Marshall provides soine insightful comments about the role of offense in Religion Clause adjudication and concludes that offense should not render laws invalid under the Establishment Clause.

502. Id. at 358-63.

503. Of course, to the extent that the government acts or speaks directly in favor of a majority rehigious faith (for example, officials publicly endorse a faith or governinent agencies hold worship services), ininority religions are apt to feel that their rights are not being protected. The argument of this Comment remains, however, that offense should not necessarily trigger Establishment Clause rehef even if that offense is the direct result of such direct governinent action.

504. Advocates of abortion rights have inade a similar argument. See Rust v. Sullivan, $111 \mathrm{~S}$. Ct. 1759, 1776-78 (1991) (rejecting abortion-rights advocates' argument that if there truly is a constitutional right to abortion, then it is the government's role to facilitate poor women's exercise of that right). While the Rust Court was ultimately unpersuaded, the logic of this argument remains strong.

The argument becomes even stronger in the context of the First Amendment. If there is a right to religious expression, then the government should facilitate that expression as much as possible as long as it is compatible with others' freedom of religious expression. To advance this goal, all citizens implicitly agree to endure some offense-even rehgious offense-to preserve everyone's right of free religious expression.

For a discussion of the analogy between government funding of abortion and government aid to religion, see Michael W. McConnell, The Selective Funding Problem: Abortions and Religious Schools, 104 HaRv. L. REv. 989 (1991).

505. Under the contractarian model, eertain objectives, such as the health and safety of citizens, are fundamental, and the government is entitled to insist that people have those services. Since these services cost money, the government is entitled either to tax the citizens and provide the services itself or to require individual citizens to obtain the services for themselves. Further, it is entitled to enforce these requirements with sanctions of some kind, as modern government does. 
tax dollars used to benefit religion. Anyone who does not believe and who, therefore, experiences this offense, has a choice between paying no taxes and incurring the consequences or paying taxes and feeling the offense.

The burden liere, lowever, is not necessarily impermissible. If the inoney is used for services or resources that enable the state to fulfill one of its core objectives, then the taxpayer would have to spend that inoney to attain tliat objective even absent the government program, because in a contractarian society the government is entitled to ensure that the objective be met-eitler througl coinpulsory taxation or soine other means. Thus, as long as the taxpayer receives a core service for his taxes, the government assistance serves a core objective.

The liarder question is whetler there are any alternative means to accoinplish the objective more effectively witlout a corresponding increase in coercive effect or any alternative means to accomplish the objective as effectively with a corresponding decrease in coercive effect. If the government's tangible assistance is given to all non-public schools for the purpose of improving the quality of education of all non-public scliool students, and if many non-public scliools liappen to be parochial, then in order to fulfill that purpose it is necessary to give aid to parochial schools. Giving inoney to all non-public schools would appear to be the only way to accoinplisli the government's core objective. Thus, under the proposed test, there probably is not a less coercive way to accomplish the objective effectively or a way to accoinplish the objective more effectively with no increase in coercion. ${ }^{506}$

VI

\section{ApPlications of the COERCION TEST}

This Part demonstrates low the proposed coercion-based Establishment Clause test applies to a variety of situations. The organization liere parallels the organization of Part II, which described the current state of the law. Since the proposed test views economic and

506. Note that the purpose here is to improve non-public school education. If the government's purpose, on the other hand, is merely to increase educational quality generally, it might, at least in theory, be able to do so by giving money to nonrehious schools only and achieve the same net degree of overall improvement in education within the jurisdiction. In this coutext, there might be a way to accomplish the core objective with less coercive effect-assuming that the non-public schools that received aid froin the government taught only subjects taught in the public schools and advanced no substantive behefs beyond those subjects.

This approach requires a relatively tight relatiouship between the government's means and ends. In contrast, it gives the government somewhat more latitude in formnlating the ends that it wants to achieve. The government asserts a "core" objective and the court determmes whether the objective can be fairly characterized as "core." The government retains discretion in an individual case, for example, whether to make its objective "improvement in education generally," "improvement in the education of all students," or "improvement in the education of all non-public school students." 
noneconomic assistance to rehigion somewhat differently, these situations are considered separately. Further, noneconomic assistance raises somewhat different issues in the educational context than in the noneducational context because the educational context involves children, who may be inore easily coerced than adults to behieve or participate im religious activities sponsored by the government.

\section{A. Economic Aid to Religion}

\section{Educational Setting: Aid to Parochial Schools}

To clarify the conclusion that aid to non-public schools does not necessarily violate the Estabhshment Clause under the proposed test, I will return to some of the actual cases in this area and apply the test to concrete fact situations. First, the transportation reimbursement program in Everson v. Board of Education ${ }^{507}$ is clearly constitutional. Admittedly, nonparticipants are burdened because tax dollars are used. Further, the government's assistance to religion may place a burden on nonbelievers. Those who would not be predisposed to support religious activities might be offended at having their taxes used for religious purposes. This offense, in turn, might make belief in the religion more attractive-if embracing the faith would reduce the level of offense.

The program does not impermissibly coerce religious participation or behief, however. As long as all of the schools to which the buses run teach subjects that the state deems necessary to a satisfactory education, the program facilitates education in all schools ${ }^{508}$-an objective that can be persuasively categorized as a core governmental objective in a contractarian state. ${ }^{509}$ Further, if the objective is characterized as aiding all schools within the jurisdiction by funding transportation, then there is no other way to accoinphish it. There is, therefore, no more effective way to accomplish the objective and no less coercive way to accomplish the objective as effectively.

It does not inatter that religion benefits from this program. The amount of tax money that each person has to pay for this transportation does not change whether the child is transported to a public or private school. If the cost to the taxpayers is unaffected by where the child is taken, then the amount of money spent by each of the taxpayers is the same anount that each has agreed to bear under the contractarian model-the same amount that each would have to pay in any event if every child attended public scliool. As long as the government is actually achieving its educational purpose with the tax dollars, this tangible

507. 330 U.S. 1 (1947).

508. The statute in Everson allowed the government to provide transportation for children to and from any schoolhouse if those children's homes were deemed "remote" from the school. Id. at 3.

509. See supra text accompanying notes 253-64. 
assistance to religion is not impermissibly coercive. ${ }^{510}$

Second, the provision of supplies and/or teacher subsidies to parochial schools discussed in Board of Education v. Allen, ${ }^{511}$ Committee for Public Education \& Religious Liberty v. Nyquist, ${ }^{512}$ and Lemon v. Kurtzman ${ }^{513}$ are not necessarily unconstitutional. The saine is true of the subsidies in Aguilar v. Felton ${ }^{514}$ to public employees who teach in private, including parochial, sclools and state sponsorship of the Shared Time and Community Education programs in School District v. Ball. ${ }^{515}$

Although these programs coerce rehigious participation by forcing taxpayers to fund religious activities, the coercion is not impermissible. The core objective of all these programs, like the purpose of the Everson prograin, is to facilitate basic education in non-public sclools. Given that the government lias undertaken the task of providing inoney for nonpublic education to soine extent, the burden of government sanctions against those who do not pay taxes to fund education is one that all taxpayers agree to incur in a contractarian society if the government so requires. Furtler, if the government deems it wise to provide some funds to private scliools to inake up for any disparity im resources between private and public school facilities, taxpayers inerely incur expenses for education that they would liave liad to incur if all children went to public school-provided that the private schools offer the same quality and degree of secular education as the public scliools. ${ }^{516}$ The benefit to rehion does not enhance the burden-state sanctions-on those wlio refuse to pay taxes that aid religion. ${ }^{517}$

510. It might be argued that the average taxpayer under the contractarian model only agrees to pay for children attendimg public school-not for children attending religious schools. In American society im particular, however, it is expected that a fixed amount of money allocated will be allocated for each student's primary and secondary education. If all children attend public school, then all of that allocated money is spent on the public school education. If some children attend private schools, in contrast, some of the allocated money goes to those institutions instead. Although the ultimate destination of some of that money might be different, the amount of money spent to fund admittedly core educational objectives is no greater than it would be if every child attended public school. The validity of the government funding, moreover, should not turn on the ultimate destination of the funds because any government-funded institution represents some behef system and the government subsidies are, therefore, potentially coercive to someone.

511. 392 U.S. 236 (1968).

512. 413 U.S. 756 (1973).

513. 403 U.S. 602 (1971).

514. 473 U.S. 402 (1985).

515. 473 U.S. 373 (1985), overruled by Bowen v. Kendrick, 487 U.S. 589 (1988).

516. Of course, the state would have to ensure that this goal was achieved by administering standardized tests to all public and nonpublic students.

517. This is true because insofar as the government does tax for educational purposes, it should get as much benefit as possible out of that money. If the government did not help private schools, then presumably private school prices would rise and some of the children in those private schools would attend public schools and demand more tax resourees. Indeed, taxpayers may actually save money when the government aids private schools. A child who would cost $\$ 1000$ per week in the public school system might cost only $\$ 500$ in tax money at a private school becanse private schools receive money from a variety of nongovernmental sources. 
If the state's objective is to ensure that education in all non-public schools is at least comparable to that of public schools, then there is probably no more effective way to do this than to give the private schools the resources necessary to achieve that level of quality. The harder question is whether there is a less coercive way to achieve the core objective as effectively. The answer turns on whether the private schools, absent the state aid, already offer the quality of education that the state deems satisfactory. If they do, then the core objective is already achieved with no coercion at all and state aid to these schools is unconstitutional.

Tax exemptions for parents of children who attend private schools inay also be constitutional because tax exeinptions are logically indistinguishable from direct money grants, and thus the analysis is the saine. Once the state determines the threshold level of education that is satisfactory and calculates the resources necessary to achieve that level, it inust use the most effective means to accomplish its core objective. If private schools already offer education that meets or exceeds the state's threshold, then additional aid to the school would be improper because the state objective is already realized with no coercive effect on taxpayers. If the schools fall below that threshold, then exactly the resources necessary to reach that level should be allowed.

Thus, in a case hike Mueller $v$. Allen, ${ }^{518}$ the exemption program for parents who incur educational expenses nay be constitutional as long as the statute granting the exeinption clearly defines "education." That definition should encompass only imstruction im specific secular subjects, not the teaching of ultimate values, which would go beyond the bounds of the core objective of providing enough education for citizens to participate in democratic government. Further, the state should only give as much aid as is required to bring the schools up to the level of educational quality that the state deems proper.

\section{Noneducational Setting}

Under the proposed test, the Establishınent Clause analysis of governmental actions in the noneducational context is identical, though the outcomes differ. Government funding for rehgious organizations to set up rehgious displays on private land is probably unconstitutional.

Such funding is coercive. Where taxpayer money is used, there is a burden on nonparticipants, who must pay taxes or face state sanctions. Similarly, nonbehevers incur a burden: they are offended at having their tax dollars spent on behalf of religion. If they believed in the religion and were, therefore, not offended, they presuinably would not incur this burden. Consequently, this burden might make belief in the religion represented by the syinbol more attractive.

518. 463 U.S. 388 (1983). 
The harder question is whether the coercion is permissible. For one thing, the objective of funding the displays may not be clear. Such funding might facilitate displays of various holday symbols at the appropriate times throughout the year. Alternatively, it might facilitate displays of "art" exhibits in public parks or on private land.

It is not clear, though, whether these purposes are "core" state objectives. While one of the government's core functions is to allow free expression, it is not necessarily a core function under the Lockean negative conception of liberty to fund as mucli expression as possible. Absent a justification implicating the welfare or healtl of the population, it is doubtful that any of these asserted secular justifications are core objectives under the contractarian model.

Even if a core objective, such as fostering citizens' mental health, could be identified, the displays probably would still be unconstitutional. There are many methods that the state could use to promote citizens' mental health. It would be hard to slow that symbolic rehigious displays are the most effective means. Further, many government means that might more effectively accomplish the objective could be less coercive. Naturally, if the government sought to einploy all possible aids to mental health, then funding religious displays might be deemed a necessary condition to realize this objective. It is doubtful, however, that the government would formulate so ambitious a goal.

Other noneducational cases yield different results. It is not clear under the proposed test whether the result in Sherbert $v$. Verner ${ }^{519}$ was correct. Where the state gives unemployment benefits to people who refuse to work on religious grounds, the state coerces nonparticipants because it forces taxpayers to participate in a religion by contributimg money. In the language of the proposed test, those who do not participate-tliose who do not pay taxes-bear a burden (the threat of imprisonment or other sanctions) that those who participate do not.

It is not clear whether this coercive effect is permissible. The objective of granting unemployment benefits to the plaintiff in Sherbert even though she did not qualify for benefits under the statute was certainly religious. The government accommodated her religious beliefs under the Free Exercise Clause. If the Free Exercise Clause, under the contractarian model, is deemed to require the government not only to allow people to practice their religions but also to make it as easy as possible for people to practice their religions, then a strong argument can be made that a core objective is achieved by the unemployment benefits and that such benefits really are the ouly way to achieve that objective.

In contrast, government grants to nonprofit orgamizations for the study of teenage pregnancy and provision of pregnancy-related services,

519. 374 U.S. 398 (1963). 
like those in Bowen v. Kendrick, ${ }^{520}$ are probably unconstitutional. Such a program is limited, to soine extent, to giving advice that is consistent with religious behiefs. Thus, the program coerces taxpayers to participate in an activity that is religious.

The core objective of the grants, presumably, is to preserve the health and safety of citizens. The government grants serve this objective if taxpayers receive the full value of the health services for which they are paying. There are less coercive ways, however, to achieve the objective as effectively. If government-funded clinics were allowed to distribute information about abortions, the mental health objective would presumably be achieved as effectively, while taxpayers would not be coerced. Such a scheme would be constitutional if no advice were given or witlheld in a way that benefitted a certain behef system-unless there was no other way to achieve the core objective more effectively with no increase in coercion or as effectively with a decrease in coercion.

On the other hand, government-granted tax exemptions to a variety of organizations, including religious groups, that can be grouped according to secular criteria are probably valid. For exainple, educational, charitable, religious, recreational, and health-related organizations might be deemed to ensure well-being in a stressful society.

Certainly, taxpayers are forced to fund the exenptions. But this coercive effect is permissible. Funding these organizations probably advances collective mental liealth. It is hard to think of additional categories of organizations that could be added to increase the government's effectiveness in advancing mental health because the existing categories are quite exhaustive. ${ }^{521}$

Furtler, no category can be substituted for "rehgious" that would accomplish the core objective as effectively with a decrease in coercion. All orgamizations in any of these categories advance soine belief system. Thus, taxpayers are already coerced. They remain coerced to the same degree no matter which category is substituted-as long as the an1ount of tax money used for this scheine remains the saine.

520. 487 U.S. 589 (1988).

521. If such a category were found, the government would be obliged to add it to the list or abandon the program. The addition of a new category would not increase the magnitude of coercion. The government would not have to increase taxes-it could just distribute the same amount of money over more categories of organizations. Admittedly, the addition of a new category to the list might coerce additional individuals' beliefs because it would add organizations that act consistently with some belief system that might not have been represented by the previous categories; therefore, people who were not previously offended at the old list of categories might be offended at the new list's additional category. As noted above, however, increase in coercive effect is not measured by the additional number of people coerced; rather, it is measured by changes in the magnitude of coercion of people originally coerced by the government act. 


\section{B. Noneconomic Aid to Religion}

\section{Educational Setting: Religion in the Public Schools}

Cases involving noneconomic assistance to religion differ from tliose involving financial aid because the forms of coercion often are inuch less tangible. For example, released timie programs in public scliools are not tax-supported, but are probably unconstitutional. Such programs do coerce religious participation, whether or not the religious instruction is on public scliool property, because tliose cliildren who do not attend rehgious instruction may feel stigmatized. This stigma can occur where one student refuses to participate in the religious activity and is someliow singled out by participating students as "different." It is quite likely that a student who is perceived as different from the majority of students will be treated unquely. The majority of students may eitlier make fun of the one who is different or at least be more lesitant to imclude the nonparticipating student im social activities. If this situation occurs, the nonparticipant incurs a burden not imcurred by participants.

The difficulty here is proving that stigma exists. Two factors are important to this determmation: (1) classroom composition; and (2) student interactions or student-teacher interactions. Composition is important because if the majority of students are participants, then a nonparticipating student's claim of stigmatization is mucli stronger tlian it would be if that student were in the majority. Indeed, there can be no stigma for nonparticipants if the majority of students are nonparticipants.

The types of interactions that occur between the nonparticipating student and the rest of the students or the teaclier are also particularly relevant. If there is evidence thiat the complaining student lias been singled out in any way by the students or by the teacher for ridicule, then stigma probably exists. Similarly, if there is evidence that participatimg students liave excluded the nonparticipant from social activities or otlierwise treated the student differently, the case for stigma is also strong. ${ }^{522}$

Released time programs miglit coerce religious belief as well. Only some religions will offer special instruction during the release periods. Students who do not believe in those religions may be offended by this special instruction. If believing in the preferred religions is one way to reduce this offense, the prograin inay render belief in some religions more attractive than that belief would liave been absent the governinental action.

Further, this coercion is probably impermissible. Suclı programs

522. Note that stigma is more than offense. The objective factors discussed here will help a court differentiate situations where the complaining student is harmed merely by being offended by the religious activity from situations where the student is constrained because of a stigma imposed because of refusal to participate in the religious activity. 
might be said to instill within students the kinds of moral values that make them more cooperative and receptive to education in the classroom. The program might, therefore, advance education. It is not at all clear, however, that this method is the most effective one to improve cooperation and receptivity. The government would have to show that no alternative methods exist to accomplish the result without increasing the stigma on nonbelievers or nonparticipants. It would be even more difficult for the government to show that no alternative means exist to achieve this goal with a decrease in coercive effect.

Other cases yield similar results. For example, it is probably unconstitutional under the proposed test to require daily prayers or daily Bible readings in public schools, as in Engel v. Vitale ${ }^{523}$ and School District $v$. Schempp. ${ }^{524}$ These programs may coerce participation because the students who choose not to participate may experience stigma. Here, it does not matter whether a majority of the students subscribe to the religion underlying the activity. Ratler, it is sufficient that a majority of students do not elect to opt out of the exercises. Because many students are likely to be indifferent to the activity, few students will probably elect to opt out.

The programs nnay also coerce belief. Those who believe in religions not represented by the verbal prayers or Bible readings may be offended. Thus, the prayers and readings render certain religious beliefs more attractive if these beliefs reduce the feeling of offense.

In order for this coercion of religious participation and belief to be permissible, it must at least serve a core function, such as facilitating more efficient learning. Instilling within the students a sense of the virtue of education and an awareness that this virtue might be rooted in a spiritual reality and the wishes of a higher, supernatural power might facilitate this learning. But there probably are other methods that could accoinphish this result as effectively with less coercive effect. It would be hard for the government to show that no such alternatives exist. Further, there might be an alternative means to accoinplish the objective even more effectively with no increase in coercion-especially if many of the students were nonbelievers and did not absorb the inessages embodied in the prayers or readings.

The display of the Ten Counnandinents on a public classroom wall, as in Stone v. Graham, ${ }^{525}$ is probably unconstitutional as well, though the existence of coercion is not immediately clear. If looking at the Commandments constitutes "participation" in a religious activity, then "nonparticipants" are those who refuse to look at the wall. These nonparticipants may be stigmatized if a majority of the students in the class

523. 370 U.S. 421 (1962) (school prayer).

524. 374 U.S. 203 (1963) (daily Bible readings).

525. 449 U.S. 39 (1980). 
believe in the Ten Commandments and voice their beliefs. The evidence of stigma is even stronger if nonbelievers are asked what they believe. If stigma is found, then the display of the Ten Commandments may be impermissibly coercive.

A stronger argument for coercion is that students may feel forced by the teacher to believe im or look at the display. If the teacher voices a belief in the Ten Commandments, then students may feel that if they refuse to look at the display, the teacher may treat them differently than the other students. The court would then have to inquire wlietlier there is any objective basis for the students' feeling. If there is an objective basis, then coercive effect can be found..$^{526}$

A harder case is presented if the teacher does not express personal religious behefs. Students might still associate the display with the teacher's beliefs and feel that if they refuse to look at the display, the teacher may penalize thein. In this situation, tlie court would have to ascertain the teacher's actual religious beliefs. If those beliefs are consistent with the Ten Commandments, then tlie court should inquire into whether the teacher treats tlie nonparticipating students differently than other students. If such differential treatment can be sliown, then there is a burden on the nonparticipant.

Even if there is no coercion of participation, there still imight be coercion of belief. Those nonbelievers who look at the wall inight be offended. The only way for them to avoid that offense is to refrain from looking at the wall.

Further, these coercive effects are probably impermissible. It is not apparent that the display serves any particular core objective. The one possible purpose is educating students about historical and/or rehious traditions underlying the founding of the Umited States. However, the government would have to show that other, less coercive methods of presenting this information are less effective in achieving this educational goal. This would probably be a hard showing to make.

When classroom activity is not overtly religious, the inquiry becomes even more difficult. A statute banning the teaching of evolution

526. It might be argued that involving the court in specific factual determinations of the demographics of classrooms in every case is problematic. Since each case will have to be judged on its individual facts, each plaintiff might have to go to court to obtain the required factual determinations. Forcing each plaintiff to do this might overload the courts. Further, plaintiffs who lack the resources to pursue cases to trial might have no effective means to virdicate their rights.

Although it is true that each case that goes to trial will require an independent factual determination, it does not follow that these undesirable consequences will occur. Prior court cases and opinions would still have precedential value to guide future potential litigants iu deciding whether to litigate or settle in light of the facts of their particular disputes. Further, rules can be devised to sanction defendants who attenpt, in bad faith, to force the plantiff with a meritorious claim to go to trial when it is reasonably clear from the beginning what the outcome of the litigation will be. 
in schools, such as the one at issue in Epperson v. Arkansas, ${ }^{527}$ may be unconstitutional. Nonbehevers in the religions that benefit from the statute might be offended, and this offense might render belief in the benefitted religions more attractive. If this coercive effect exists the statute is probably unconstitutional, because there is no apparent core justification for it.

However, a statute requiring equal treatment of evolution and "creation science" in public school classrooms ${ }^{528}$ is probably constitutional. Although nonbelievers might be offended, this offense is tolerable if the government's goal is to distribute as much information as possible on all of the theories about low life began. In fact, if this is the objective, there is no alternative means that would be more effective or equally effective but less coercive, assuming that all theories of creation and evolution are addressed in the classroom.

Moinents of silence in the classroom present the inost difficult questions. The determination of coercive effect in this context turns on whether those who decline to pray during this period are stigmatized. For example, if during the moment of silence, soine students are silent but many students bow their heads or inake praying gestures, then those who decline to make tlose moveinents might feel conspicuous. This feeling might rise to the level of stigma if the praying students become aware of others' refusal to pray and treat the non-praying students differently. Similarly, if only one student inakes praying gestures during the period and the other students treat that participating student differently for this reason, the resulting stigma renders the government practice coercive.

The periods of silence also might coerce religious belief. Only those whose rehigions practice silent prayers can take full advantage of the quiet periods to pray. Those whose beliefs include louder or more active prayer rituals might be offended by the inoments of silence. The moments of silence, then, conceivably place a burden on certain nonbelievers that makes belief im certain religions more attractive.

It is not clear whether this coercive effect is permissible. The probable justification for sucl inoments of silence is that they calm students down and enable thein to develop their reflective and introspective abilities. These abilities might carry with them increased mental discipline to make children better able to learn. They might also allow students to develop a greater existential awareness and, in turn, a better sense of the ultimate value of education. This sense iniglit make them more motivated to learn.

Although there are other ways to accomplish this goal, it is not clear that there are any more effective ways to do so. Further, it is not clear

527. 393 U.S. 397 (1968).

528. See, e.g., Edwards v. Aguillard, 482 U.S. 578 (1987) (striking down a statute that required such "equal" treatment). 
that a less coercive method exists to accomplish the result as effectively. The most likely competing alternative would be soine sort of inusic or visual presentation. The burden would be on the government to show that these alternatives are no more desirable under the proposed test.

\section{Noneducational Setting}

Cases involving noneconomic assistance to religion outside of the educational context also present questions of varying difficulty. It is unclear, for example, whether Sunday closing laws like the one in McGowan v. Maryland ${ }^{529}$ are constitutional under the proposed test. Nonparticipants in this context are those who refuse to participate in the religious activity-i.e., those who refuse to obey the Sunday closing laws. Such persons face the burden of sanctions by the state if they insist on business as usual on Sunday.

Similarly, nonbelievers-those whose religions do not hold services on Sunday-might be burdened. Such persons do not liave the option of practicing their religious activities on their inandatory day off. Thus, belief $\mathrm{im}$ rehigions whose believers can practice their religious activities on their inandatory day off might become more attractive.

The question then becomes whether the coercion is permissible. The most likely core objective of such laws is protecting the health of workers who might otherwise not get time off from work. It is not clear whether there are any inore effective ways to accomphish this objective. However, there might be a way to accomplish this objective as effectively with less coercion. The government might, for example, carve out specific hours each day during which businesses would be required to close or try to find a day during which no behefs are celebrated or observed.

Another significant example is legislative prayer, which was challenged in Marsh v. Chambers. ${ }^{530}$ If public money funds legislative prayer, then the activity is burdensome because taxpayers are forced to pay for it. Nonparticipants in this rehgious activity incur the burden of state sanctions for nonpayment of taxes. If no public money is used, a coercive effect on nonparticipants might still exist because of the possibility of stigma, and a coercive effect on nonbelievers inight exist because of the possibility of offense.

One possible secular justification is enabling the legislators to reflect on the gravity of their responsibilities and allowing them to seek soine spiritual or inoral guidance to make them more effective in governing. If the prayers actually increase the effectiveness of the legislators in any ineasurable sense, then they probably do serve a core function. However, a moinent of silence might accomphish this function as effectively with

529. 366 U.S. 420 (1961).

530. 463 U.S. 783 (1983). 
less coercive effect. Thus, legislative prayer, whether tax-supported or not, is probably unconstitutional unless an independent core objective can be found to justify the practice.

The most controversial cases in this category involve public displays during the Christmas season. ${ }^{531}$ Under the proposed test, such displays are constitutional if the state does not fund them. ${ }^{532}$ The effects of these displays are probably not coercive. Arguably, no burden is placed on nonbelievers and nonparticipants that is not incurred by believers and participants.

It might be argued that those who refuse to participate by looking at the symbols will be stigmatized. This might occur if a majority of passers-by do participate in the rehgious activity by looking at the display, notice that a few refuse to participate, and single those nonparticipants out for unfavorable social treatment. While this is possible, it is unlikely in an outdoor setting, where many people pass by the display, that participants will notice a particular person's response to the display. Even if they do notice, it is unlikely that the nonparticipant will be singled out in such a street settimg for unfavorable treatment.

In addition, the presence of such displays on public property will offend soine nonbehevers. It is also logical to assume that a few believers will be offended at what they perceive to be the "watering down" or secularization of sacred symbols. People in these categories do incur a burden. They must either be offended or walk down the street without looking at the display. Further, if it is true that nonbelievers are more likely to be offended than behevers, and an individual's offense stems from nonbehef, the display might make belief in the religion more attractive than it would otherwise be.

Even if nonbelievers and nonparticipants incur a burden not incurred by believers and participants, however, that burden is permissible in a contractarian society. The core governmental objective is likely to be facilitation of expression of as many beliefs as possible. One expects, in such a society, to see a variety of symbols in many locations in American society. Some of these symbols are offensive, but the members of a society that places a premium on free expression accept this consequence. Further, the government is expected to facilitate this expression by allowing expression in public places. ${ }^{533}$

531. See, e.g., County of Allegheny v. ACLU, 492 U.S. 573 (1989).

532. It could be argued that any use of public land for a religious purpose amounts to financial aid to religion because the property is tax-maintained. However, if the religious activity does not add to the land's maintenance costs, the government's benefit to religion imposes no burden on taxpayers.

533. It is worth noting that the proposed test applies to any such display on public propertyregardless of the belief or belief system that the display represents. Most Establishment Clause challenges in this context have involved displays representing traditionally established faiths like Christianity and Judaism. Nevertheless, a display that represented atheism-or even Satanism- 
There is no more effective way to maximize expression of ideas than to allow that expression. Further, allowing such expression only on private land might not be as effective because some minority belief systems might not have access to as much private land as majority behief systems. Indeed, they might not have access to private land at all. Further, it is unclear how allowing such expression only on private property would reduce the coercive effect if such land was accessible to public view.

The most difficult case for the coercion test to resolve, however, is one where a church claims an exemption from anti-discrimmation laws. Thus, in Corporation of the Presiding Bishop of the Church of Jesus Christ of Latter-Day Saints v. Amos, ${ }^{534}$ the Mormon Church claimed that all of its organizations shonld be permitted to hire only Mormons. The effect is certainly coercive. A burden is placed on those who refuse to embrace the Mormon faith that is not placed on those who do. Further, that burden makes belief $\mathrm{m}$ the Mormon religion more attractive than it otherwise would be.

However, the coercive effect is probably permissible. The government's asserted justification is likely to be vimdicating rights of the Mormon church under the Free Exercise Clause-a core contractarian objective. Further, the purpose of a church is not only to support its membership in its faith but also to increase the number of its adherents. The Madisonian vision of religious hiberty acknowledges and approves of this purpose. ${ }^{535}$ Further, in the public sphere, the government should allow as much of this rehigious activity as is consistent with the core values that the state was created to uphold.

Of course, one of those core values is formal equality. In this case, however, the discrimination is on the basis of religion and the discriminatimg parties claim that their religion requires them to discriminate. Arguably, one expects rehigious groups to give special treatment to their members because such treatment reinforces the common values and experiences shared within the groups. If a religion's doctrine requires such differentiation between members and nonmembers, there would seem to be no alternative means that is as effective or more effective to vindicate Free Exercise rights than to allow the religious requirement to be fulfilled. Naturally, this result would depend on a strong showing by the church that its religious doctrine actually requires such differentiation.

would be subject to the same kind of analysis as the displays at issue in the cases that have reached the Supreme Court. This conclusion is consistent with free speech doctrine, which prohibits the government from barring speech on public property merely because that speech is offensive. See, e.g., R.A.V. v. St. Paul, 112 S. Ct. 2538, 2550 (1992) (rejecting the criminalization of hate speech). In fact, the government may bar expression in public places only in extremely limited circumstances.

534. 483 U.S. 327 (1987).

535. See supra text accompanying notes 323-25. 
VII

\section{CONCLUSION}

The Supreme Court's current approach to Establishment Clause cases reflects conflicting values that have led to a set of decisions with no unifying principles. This lack of uniformity is unacceptable because it threatens rehgious hiberty, the very value that the Establishment Clause was designed to uphold. Inconsistent application of the Clause protects the liberty of some, but not others. We leave such important decisions in the hands of courts precisely because we believe that they are able to make these decisions in a principled manner. If they cannot do so, then their legitimacy as protectors of important constitutional rights is undermimed.

Coercion, properly defined, is the most promising construct on which to build a consistent approach to the Establishment Clause. It is rooted in the mdividualist underpinnings of the First Amendment and, therefore, it is the most effective imstrument to protect individual religious liberty. Further, the definition presented here grounds coercion in the contractarian model of society contemplated by the Constitution. Accordingly, the proposed test facilitates niformed and sensible judgment about what constitutes a threat to an individual's religious liberty.

The proposed test does not necessarily make each Establishment Clause decision easier. These cases still require fact-sensitive inquiries, the outcomes of which cannot be predicted in advance. Nevertheless, by ensurimg principled decisioninaking, the proposed test guarantees that the law will protect rehgious hiberty in all cases. 